\title{
Small-Molecule Inhibitors of the NusB-NusE Protein-Protein Interaction with Antibiotic Activity
}

Peter J. Cossar, ${ }^{\dagger}$ Mohammed K. Abdel-Hamid, ${ }^{\dagger, \S \odot ~ C o n g ~ M a, ~}{ }^{\ddagger}, \#$ Jennette A. Sakoff, ${ }^{\| \odot ~ T r i e u ~ N . ~ T r i n h, ~}{ }^{\dagger}$

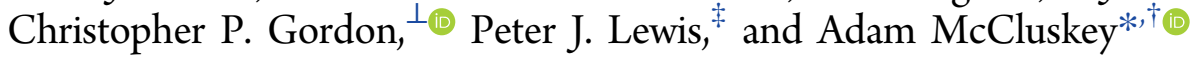

${ }^{\dagger}$ Chemistry, School of Environmental \& Life Sciences and ${ }^{\ddagger}$ Biology, Centre for Chemical Biology and Clinical Pharmacology, School of Environmental \& Life Sciences, The University of Newcastle, University Drive, Callaghan, NSW 2308, Australia

${ }^{\S}$ Department of Medicinal Chemistry, Faculty of Pharmacy, Assiut University, Assiut 71526, Egypt

"Experimental Therapeutics Group, Department of Medical Oncology, Calvary Mater Newcastle Hospital, Edith Street, Waratah, NSW 2298, Australia

${ }^{\perp}$ Nanoscale Organization and Dynamics Group, School of Science and Health, University of Western Sydney, Penrith South DC, NSW 2751, Australia

Supporting Information

ABSTRACT: The NusB-NusE protein-protein interaction (PPI) is critical to the formation of stable antitermination complexes required for stable RNA transcription in all bacteria. This PPI is an emerging antibacterial drug target. Pharmacophore-based screening of the mini-Maybridge compound library (56000 molecules) identified $N, N^{\prime}$-[1,4-butanediylbis(oxy-4,1-phenylene)]bis( $N$-ethyl)urea 1 as a lead of interest. Competitive enzyme-linked immunosorbent assay screening validated 1 as a $20 \mu \mathrm{M}$ potent inhibitor of NusB-NusE. Four

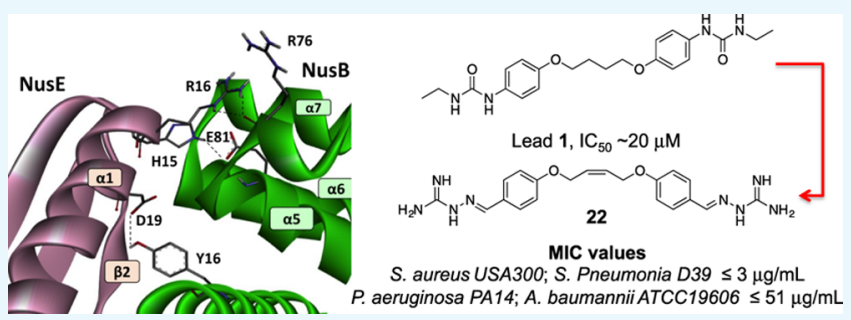
focused compound libraries based on 1, comprising 34 compounds in total were designed, synthesized, and evaluated as NusBNusE PPI inhibitors. Ten analogues displayed NusB-NusE PPI inhibition $\geq 50 \%$ at $25 \mu \mathrm{M}$ concentration in vitro. In contrast to representative Gram-negative Escherichia coli and Gram-positive Bacillus subtilis species, these analogues showed up to $100 \%$ growth inhibition at $200 \mu \mathrm{M}$. 2-((Z)-4-(((Z)-4-(4-((E)-(Carbamimidoylimino)methyl)phenoxy)but-2-en-1-yl)oxy)benzylidene)hydrazine-1-carboximidamide 22 showed excellent activity against important pathogens. With minimum inhibitory concentration values of $\leq 3 \mu \mathrm{g} / \mathrm{mL}$ for Gram-positive Streptococcus pneumoniae and methicillin-resistant Staphylococcus aureus and $\leq 51 \mu \mathrm{g} / \mathrm{mL}$ for Gram-negative Pseudomonas aeruginosa and Acinetobacter baumannii, 22 is a potent lead for a novel antibacterial target. Epifluorescence studies in live bacteria were consistent with 22, inhibiting the NusB-NusE PPI as proposed.

\section{INTRODUCTION}

Antibiotics are pivotal to modern medicine. They enable clinicians to conduct invasive surgery, treat immune-compromised patients, and carry out blood transfusions on trauma victims with a minimal risk of death due to secondary bacterial infections. ${ }^{1,2}$ However, the prevalence of multidrug-resistant bacteria threatens our ability to survive clinically and community-acquired infections. This increasing prevalence of multidrug-resistant bacteria has the very real potential to undermine all of these significant medical advances.

Antibiotic-resistant bacteria are estimated to result in 48000 deaths annually in the United States and Europe. ${ }^{3,5}$ Of equal concern is that the Food and Drug Administration (FDA) approved only one new antibiotic in 2015, Avycaz (avibactam/ ceftazidime), for the treatment of complicated intra-abdominal infections. ${ }^{6}$ This lack of innovation and investment has meant that a number of multidrug-resistant bacterial strains, particularly the "ESKAPE" pathogens: Enterococcus faecium, Staphylococcus aureus, Klebsiella pneumoniae, Acinetobacter baumannii, Pseudomonas aeruginosa, and Enterobacter species, are extremely challenging to treat and, in some cases, require complex antibiotic cocktails. ${ }^{7}$ Potentially of greater concern is that the current antibiotic development places considerable emphasis on new iterations of existing drugs, and hence these agents are vulnerable to the rapid acquisition of resistance from the dissemination/modification of the preexisting mechanisms. ${ }^{8}$ Clearly, there is a pressing need to develop new antibiotic classes, especially those with a lower inherent resistance susceptibility., ${ }^{4-12}$ As a result, global strategies, such as "The $10 \times 20$ Initiative", seek to combat this crisis, and this initiative has the ambitious target of 10 new antibacterial drugs by $2020 .^{13}$

Key to the development of next-generation antibacterial agents is the identification of new drug targets, and, to this end, there is a growing focus on interrogating the bacterial interactome to identify essential protein-protein interactions

Received: March 8, 2017

Accepted: June 29, 2017

Published: July 25, 2017 
A

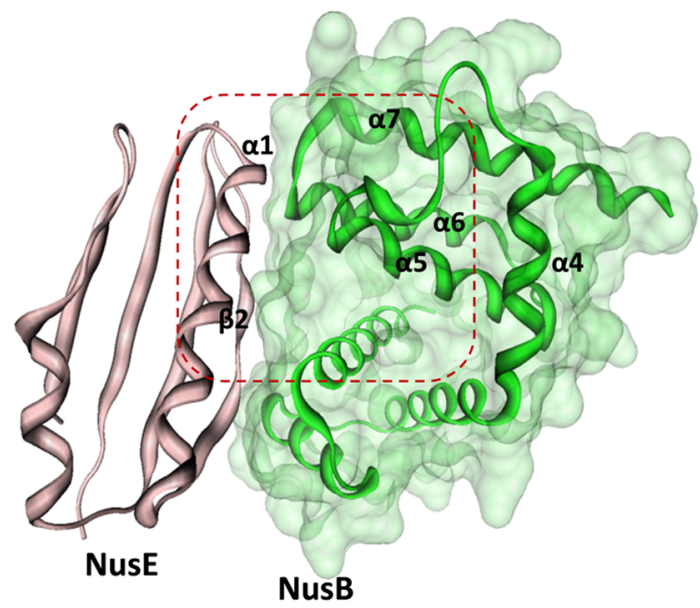

D

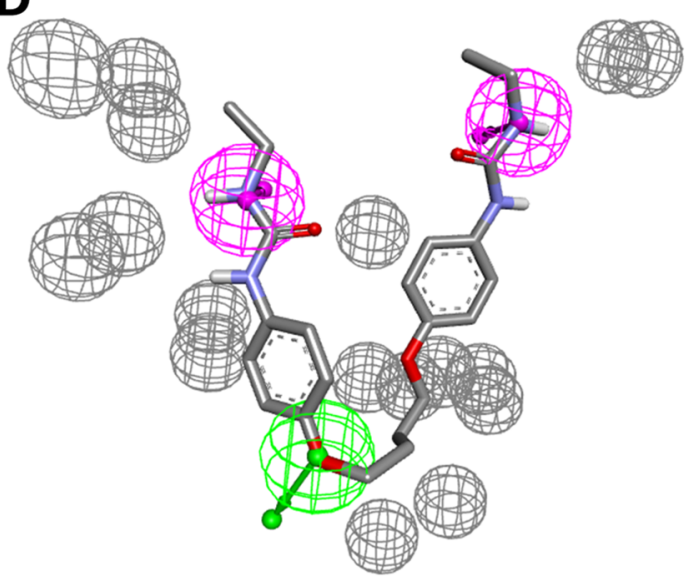

B
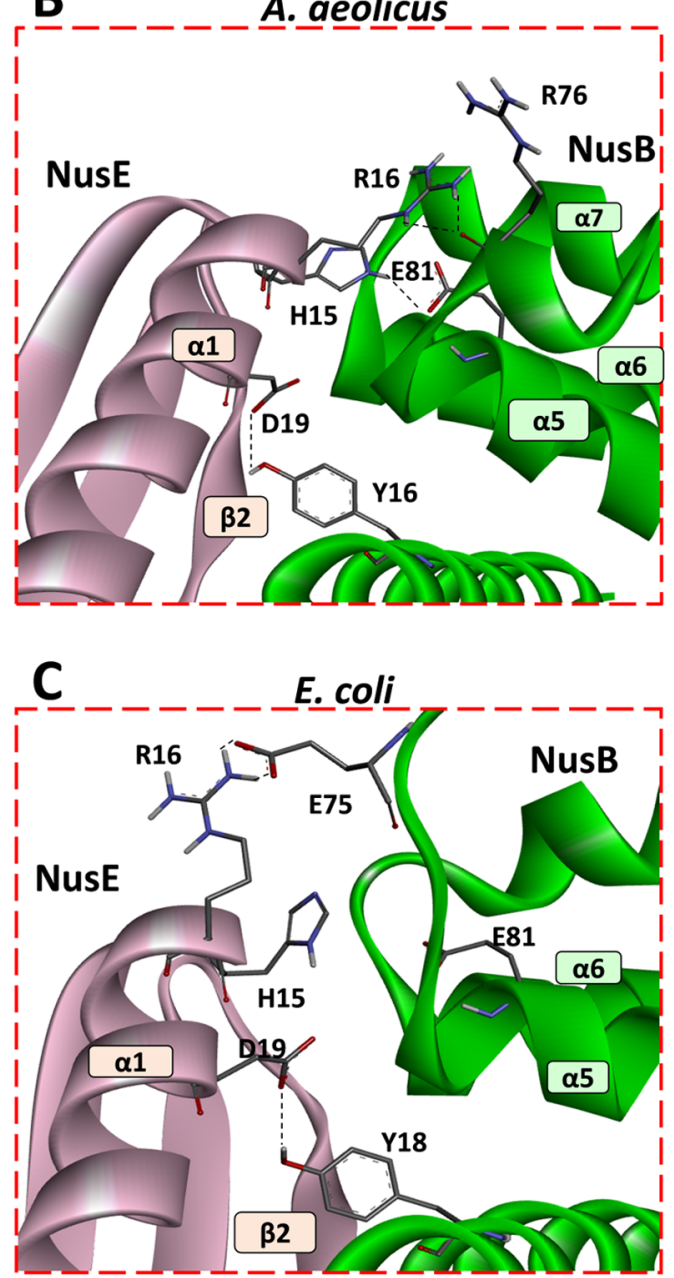

Figure 1. (A) Cocrystal structure of A. aeolicus NusB-NusE (PDB ID: 3R2C). (B) Enlarged region of the A. aeolicus NusB-NusE PPI interface with the amino acids (as sticks) involved in PPIs, with the black dashed lines indicating key hydrogen-bonding interactions between H15, R16, and D19 of the $\alpha 1$-helix of NusE and Y16, R76, and E81 of NusB. (C) Enlarged region of the E. coli NusB-NusE PPI interface with the amino acids (as sticks) involved in PPIs, with the black dashed lines indicating key hydrogen-bonding interactions between H15, R16, and D19 of the $\alpha 1$-helix of NusE and Y18, E75, and E81 of NusB. (D) Pharmacophore model based on the NusE amino acids responsible for binding with NusB, with 1 fitted into the pharmacophore. Purple sphere: hydrogen bond donor; green sphere: hydrogen bond acceptor; gray sphere: exclusion zone.

(PPIs). These PPI networks can, in principle, be targeted by small-molecule inhibitors. ${ }^{14-16}$ To date, the inhibition of PPIs has proved fruitful, with multiple PPI-targeted drugs receiving FDA approval, including Lifitegrast, Venetoclax, and Birinapant. ${ }^{17,18}$ These accomplishments have validated PPIs as drug targets, thus opening up opportunities to develop new classes of antibacterial agents. 18,19

A typical PPI is predominantly hydrophobic in nature, with a handful of polar residues located centrally across a protein surface of area 1000-2000 $\AA^{2}$. The polar, and nearby hydrophobic, residues give rise to critical small "hot spots" and impart a significant proportion of the binding energy responsible for the observed PPI. ${ }^{18,20,21}$ These hot spots and the presence of a degree of conformational flexibility make targeting PPI an attractive potential therapeutic intervention. One such PPI in the bacterial interactome is the interface between the transcription factors, NusB and NusE.

The NusB-NusE PPI is a critical nucleation point for the formation of the antitermination complex enabling the regulation of bacterial stable ( $\mathrm{t}$ - and $\mathrm{r}-$ ) RNA transcription. ${ }^{22}$ In the Gram-negative model, Escherichia coli, point mutations, for example, nusE100 (R72G) ${ }^{23}$ and nusB5 (Y18D), ${ }^{24}$ result in a reduced protein-protein binding affinity, affecting the formation of the antitermination complex. ${ }^{24,25}$ Strains nusE100 and nus B5 are unable to efficiently transcribe the $16 \mathrm{~S}$ and $23 \mathrm{~S}$ ribosomal transcripts, which impedes the formation of new ribosomes and leads to reduced growth, ${ }^{26,27}$ demonstrating the importance of the NusB-NusE binding interface.

The examination of the Aquifex aeolicus (PDB: 3R2C) and E. coli (3D3B) NusB-NusE heterodimer crystal structures reveals a PPI surface area of $\sim 1600 \AA^{2}$ (Figure 1A). ${ }^{25,28}$ The PPI interface comprises a mixture of hydrophobic and hydrophilic interactions resulting from helix $\alpha 1$ and strand $\beta 2$ of NusE bridging the two helical bundles of NusB (Figure 1A-C). Because of the complexity of biomacromolecules under physiological conditions, significant differences typically exist between the NMR and X-ray crystallographic structures of the same protein and so we chose to use both the NMR and crystal structures of $A$. aeolicus and $E$. coli proteins to reveal the major hydrogen-bonding contributions. ${ }^{25,28,29}$ As seen in Figure 1B,C, these occur between NusB E81 (E. coli E81)-NusE H15 (E. coli H15), NusB Y16 (E. coli Y18)-NusE D19 (E. coli D19), and NusB R76 (E. coli E75)-NusE R16 (E. coli R16) 
interactions (Figure 1B). The NusB E81 (E. coli E81)-NusE $\mathrm{H} 15$ (E. coli H15) interaction is absent in the E. coli crystal structure, ${ }^{25}$ which is consistent with the high relative B factors observed, indicative of the conformational flexibility in those regions in both the A. aeolicus and E. coli protein crystal structures (PDB IDs: 3R2C and 3D3B, respectively). A close examination of the modeled interface highlights a potentially key interaction between the E. coli E81 and $\mathrm{H} 15$ residues and reflects the structural information in solution. ${ }^{29}$ Subsequently, we developed a hybrid NusB-NusE interface using the information from the $A$. aeolicus NMR study and the crystal structure, as well as the E. coli crystal structure (Figure $1){ }^{25,28,29}$ which united the structural information from both techniques and two species.

Previously, we reported the development of a pharmacophore model, on the basis of the published NMR and X-ray crystallography structures of the NusB-NusE PPI of A. aeolicus and E. coli. ${ }^{30}$ This model merged key structural information from three different studies and two bacterial species. ${ }^{25,28,29}$ Critical to this model was the $\alpha 1$-helix sequence of NusE, which interacts with the binding groove of NusB. Three critical hydrogen bond interactions between the $\alpha 1$-helix of NusE (D19, R16, and H15) and the binding groove of NusB (Y16 (E. coli Y18), R76 (E.coli E75), and E81), as shown in Figure 1B,C, were manually plotted to generate a pharmacophore (Figure 1D). Screening of this pharmacophore against the miniMaybridge compound library (56000 molecules) identified 25 hits. A pharmacophore validation was then conducted using a competitive enzyme-linked immunosorbent assay (ELISA)based screen and a subset of hits, which were synthesized inhouse. From the screen 1,1'-((butane-1,4-diylbis(oxy))bis(4,1phenylene))bis(3-ethylurea), 1 was identified as a $19.8 \pm 1.7$ $\mu \mathrm{M}$ inhibitor of the NusB-NusE PPI (Figure 2). ${ }^{30}$

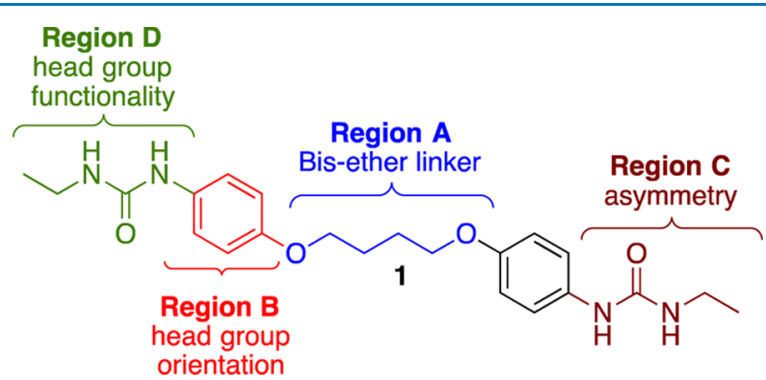

Figure 2. Chemical structure of 1,1'-((butane-1,4-diylbis(oxy))bis(4,1phenylene))bis(3-ethylurea) 1 identified through in silico screening of the mini-Maybridge library and ELISA screening of the NusB-NusE interaction as a $20 \mu \mathrm{M}$ potent inhibitor of the NusB-NusE PPI. Also depicted are the four regions identified for modification and SAR generation.

Herein, we report the computational and biological screening-guided design, synthesis, and characterization of four structural activity relationship libraries, which focus on modifications to four key regions of lead $\mathbf{1}$, the bis-ether linker region (A), head-group orientation (B), role of asymmetry (C), and head-group functionality (D), to develop inhibitors of the bacterial PPI between NusB-NusE as potential antibacterial agents (Figure 2).

\section{RESULTS AND DISCUSSION}

In this work, our previously developed pharmacophore was ported to the molecular operating environment (MOE) software and used to perform the docking analysis of 1 with the NusB A. aeolicus (PDB: 3R2C) interface. ${ }^{31,32}$ After initial docking of $\mathbf{1}$ at the NusB interface, the docked system was subjected to a short molecular dynamics cascade (production step of $2 \mathrm{~ns}$ at $300 \mathrm{~K}$ ), which revealed the predicted pose for 1 as "horseshoe-like" that enabled key hydrogen bond interactions with Y16, R76, and E81 consistent with the initial pharmacophore in silico screening of the mini-Maybridge compound library (Figure 3).

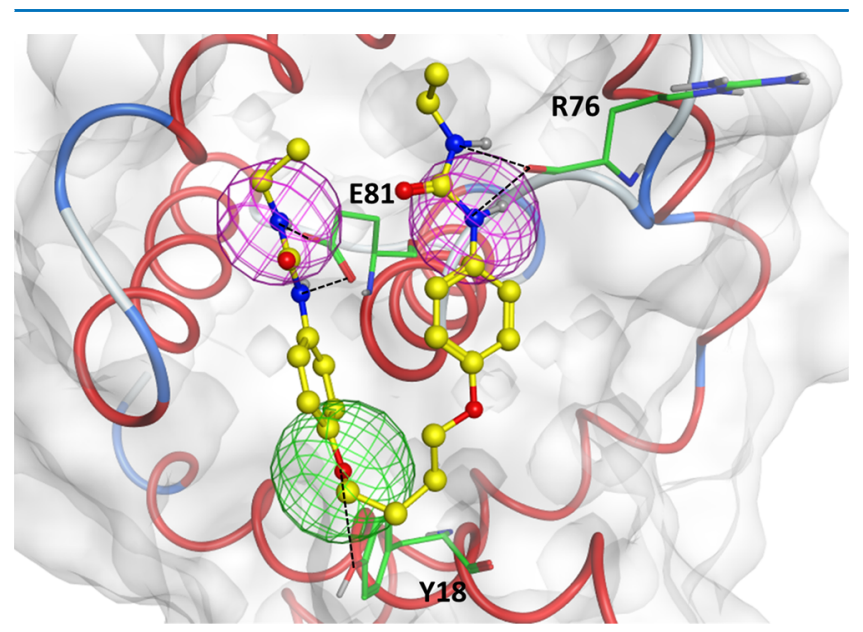

Figure 3. Docking study of lead $\mathbf{1}$ at the proposed A. aeolicus (PDB: 3R2C) NusB-NusE interface (stick representation, carbon atoms are shown in yellow). The pharmacophore features are shown as spheres, namely, hydrogen bond donor (pink) and hydrogen bond acceptor (green). Predicted hydrogen bond interactions with key residues (green) are shown as dashed lines. Compound $\mathbf{1}$ shows a horseshoe orientation with one ether oxygen hydrogen bonding with the side chain of Y18 and the adjacent urea moiety hydrogen bonding with E81 (side chain) and R76 (backbone).

On the basis of the above docking study, analogues 10a-c were designed to probe the optimal linker length, whereas 10d would examine the impact of heteroatom incorporation. The remaining analogues in this library, $\mathbf{1 0 e}-\mathbf{i}$, were proposed to explore the optimum turn radius of the "horseshoe" binding conformation (Scheme 1). The synthesis of the focused library commenced with the coupling of 4-nitrophenol 2 under modified Finkelstein conditions with $\alpha, \omega$-dichloro linkers $5 \mathbf{a}-\mathbf{c}$ to give the corresponding bis-ethers $\mathbf{6 a}-\mathbf{c}$. Flow hydrogenation (ThalesNano H-cube) over Raney $\mathrm{Ni}$ facilitated a quantitative conversion to the corresponding amines $\mathbf{8 a}-\mathbf{c}$. The treatment of these amines with ethyl isocyanate afforded the desired urea analogues $10 a-c$. In an effort to generate hydrogenationsusceptible linkers (e.g., alkenes $\mathbf{8 e}$ and $\mathbf{8 f}$, Scheme 1), the synthesis commenced with the corresponding N-Boc-4-aminophenol 3, followed by coupling with the appropriate $\alpha, \omega$ dichloro linker $5 e$ and $5 f$ to afford $7 e$ and 7 f. Boc removal ( $\mathrm{HCl} /$ dioxane) and coupling with ethyl isocyanate gave the desired urea analogues $10 \mathrm{e}$ and $10 \mathrm{f}$. Bis-ureas $10 \mathrm{~g}-\mathbf{i}$ were accessed by an alternative pathway, where 4 -aminophenol 4 was treated with ethyl isocyanate, yielding urea 9, followed by coupling with an $\alpha, \omega$-dichloro linker to give the desired compounds. This urea-based library, 10a-f, was evaluated for their ability to inhibit the NusB-NusE PPI using a Bacillus subtilis NusB and a glutathione-S-transferase (GST)-tagged NusE competitive ELISA. These data are presented in Table 1.30 
Scheme 1. Reagents and Conditions ${ }^{a}$

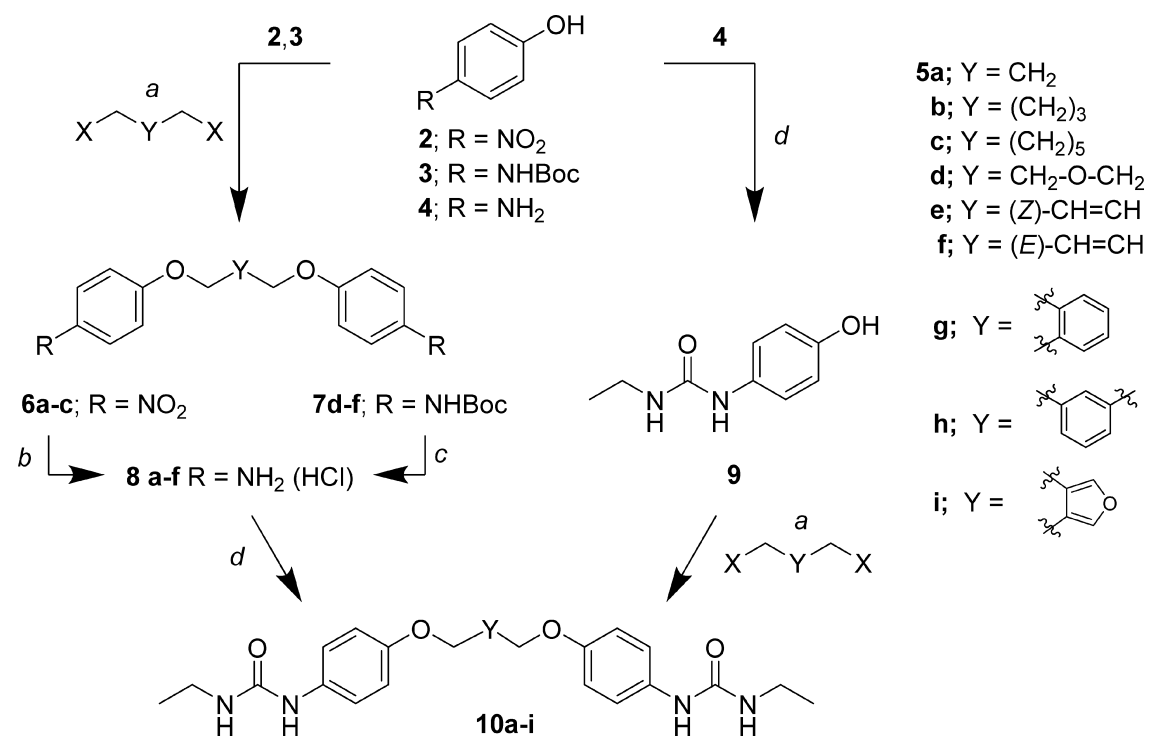

a (a) $\mathrm{Cs}_{2} \mathrm{CO}_{3}$, KI, $\mathrm{CH}_{3} \mathrm{CN}, 5 \mathrm{a}-\mathrm{i}$, reflux, 16 h; (b) ThalesNano H-Cube, $50 \mathrm{mM}$ in 1,4-dioxane, Raney Ni (30 or $70 \mathrm{~mm}$ cartridge) $50{ }^{\circ} \mathrm{C}, 50$ bar, 0.5 $\mathrm{mL} \mathrm{min}{ }^{-1}$, recirculated; (c) $4 \mathrm{M} \mathrm{HCl}$ in dioxane, sonication, $30 \mathrm{~min}$; (d) ethyl isocyanate, $\mathrm{Et}_{3} \mathrm{~N}$, anhydrous tetrahydrofuran (THF), reflux, $16 \mathrm{~h}$.

Table 1. Inhibition of the NusB-NusE Binding by 1 and $10 \mathrm{a}-\mathrm{i}$ at $25 \mu \mathrm{M}$ Compound Concentration Using an ELISA

\begin{tabular}{|c|c|c|}
\hline Compound & Linker (Y) & NusB-NusE PPI Inhibition (\%) \\
\hline 1 & $\mathrm{CH}_{2} \mathrm{CH}_{2}$ & 52 \\
\hline $10 \mathbf{a}$ & $\mathrm{CH}_{2}$ & 59 \\
\hline $10 b$ & $\mathrm{CH}_{2} \mathrm{CH}_{2} \mathrm{CH}_{2}$ & 55 \\
\hline 10c & $\mathrm{CH}_{2}\left(\mathrm{CH}_{2}\right)_{3} \mathrm{CH}_{2}$ & 7 \\
\hline 10d & $\mathrm{CH}_{2} \mathrm{OCH}_{2}$ & 22 \\
\hline 10e & 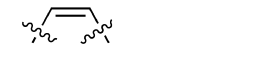 & 72 \\
\hline $10 f$ & s- & 16 \\
\hline $10 \mathrm{~g}$ & & 65 \\
\hline $10 \mathrm{~h}$ & & 10 \\
\hline $10 \mathbf{i}$ & & 12 \\
\hline
\end{tabular}


The examination of the data presented in Table 1 indicated that minor adjustments to the linker length were tolerated with 1, 10a and 10b displaying 52-59\% inhibition of the NusBNusE PPI at $25 \mu \mathrm{M}$. However, elongation to heptyl 10c removed the activity, as did the incorporation of an ether linker 10d (Table 1). In keeping with the docking study prediction, the introduction of turn-inducing linkers $10 \mathrm{e}$ and $10 \mathrm{~g}$ afforded an increase of activity to 72 and $65 \%$ respectively. Hence, the turn radius appears crucial as the 1,3-disubstituted phenyl derivative $10 \mathrm{~h}$ and the furan derivative $10 \mathrm{i}$ displayed a marked reduction in activity. With analogue $\mathbf{1 0 h}$, the data suggest that the turn radius was too high for efficient positioning of the urea head groups essential for hydrogen bonding with D75, R76, and E81. Furan 10i also showed a loss in activity, which was most likely a consequence of the introduction of a heteroatom to the linker (cf. 10d). The diminished activity of 10i and 10d, in addition to the visual inspection of the docked compounds, suggested that the hydrophobic cleft shaped by L20, Y79, and V80 of the NusB-binding groove does not tolerate electronegative atoms (Figure 4). This hypothesis was further supported by the improved binding affinity of hydrophobic linkers $10 \mathrm{e}$ and $\mathbf{1 0 g}$.

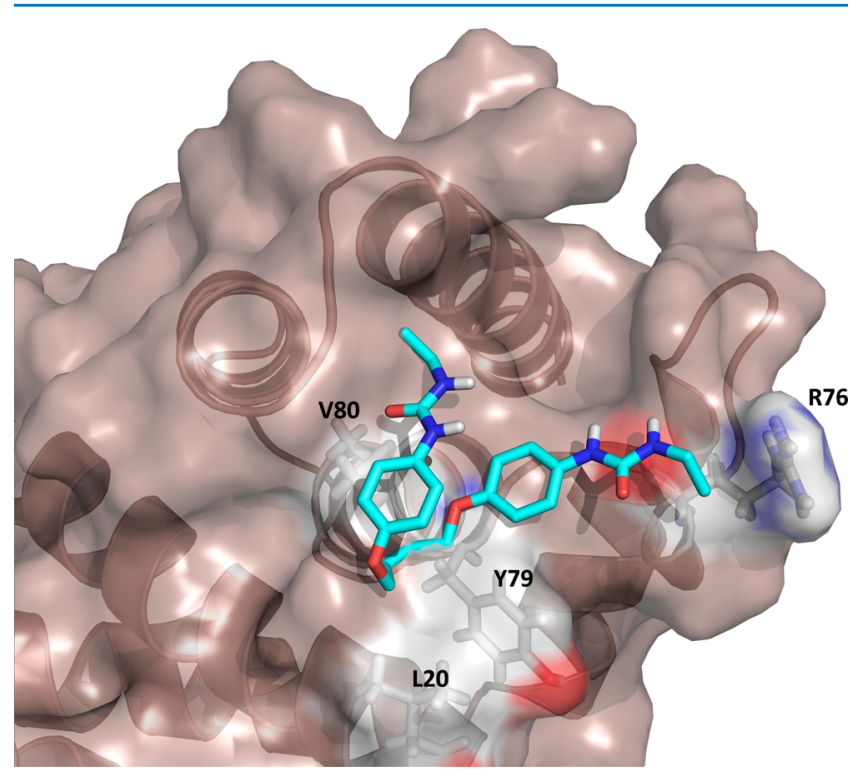

Figure 4. Docking studies of $10 \mathrm{e}$ at the proposed A. aeolicus NusBNusE interface, with the stick representation of atoms colored by type. Key amino acids L20, Y79, and V80 that form the hydrophobic cleft, which interacts with the hydrophobic linker region of $10 \mathrm{e}$, are depicted. In addition, the close proximity of R76 (side chain) to the ethylurea head group of $10 \mathrm{e}$ is shown.

The initial docking study of $\mathbf{1}$ indicated that one of the urea moieties adopted an orientation in close proximity to R76 (Figures 3 and 4). This suggested that a modification of the urea moiety may affect the binding affinity of subsequent analogues. As a result, we explored the development of a second library based on 10e. The initial focus turned to the positioning of the pendent urea moieties through the synthesis of the remaining 1,2- and 1,3-substituted ureas. These analogues were synthesized according to Scheme 1, commencing from the corresponding $\mathrm{N}$-Boc-2-phenol and N-Boc-3phenol to give $\mathbf{1 0} \mathbf{j}$ and $\mathbf{1 0 k}$, respectively (Table 2 ). We also examined the effect of installation of a single urea isostere with a retention of one urea moiety, giving asymmetric analogues 13a-i. The synthesis of these asymmetric analogues commenced from mono-urea 9 , which was coupled with $(Z)$ 1,4-dichloro-2-butene 5c, giving 11, which, in turn, was treated with a range of substituted phenols to give rise to $13 a-i$ (Scheme 2). The asymmetric $13 \mathbf{a}-\mathbf{i}$ were screened for their ability to inhibit the NusB-NusE PPI using an ELISA, and the data are presented in Table 2.

As demonstrated by the data presented in Table 2, 10j and 10k were significantly less active than 10e, supporting a 1,4substitution pattern as a requirement for inhibitory activity. Additionally, 13a-i were less active at $25 \mu \mathrm{M}$ than 10e, indicating that a urea moiety is a curial component of the binding affinity. Within the asymmetrically substituted library, $13 \mathrm{i}$ was the most potent compound, inhibiting $50 \%$ of binding at $25 \mu \mathrm{M}$.

Having identified the crucial role of a urea moiety, the subsequent library investigated a series of urea bioisosteres. As outlined in Scheme 3, compounds $\mathbf{1 5 a}-\mathbf{f}$ were synthesized under standard second-order nucleophilic substitution conditions to afford the desired bis-ether derivatives. $N$ Methylacetamide $\mathbf{1 6}$ was accessed by the treatment of $8 \mathrm{e}$ with acetyl chloride. Thiourea 17 was synthesized by the reaction of $\mathbf{8} \mathbf{e}$ with ethyl isothiocyanate in the presence of triethylamine. Saponification of $\mathbf{1 5 e}$ yielded carboxylic acid 18, which underwent amide coupling with methylamine to give 19 . Nitrile 15d provided oxadiazole 20 in two steps, and on treatment with trimethylaluminum and ammonium chloride afforded the imidamide $\mathbf{2 1}$. Finally, compound 22 was accessed via a microwave-facilitated imine formation using aldehyde $\mathbf{1 3 f}$ and a catalytic amount of $\mathrm{HCl}$ and aminoguanidine. These analogues were screened for their ability to inhibit the NusBNusE PPI, and the data are presented in Table 3.

The moderate activity of $\mathbf{1 8}$ aligned with the initial docked conformation (Figure 4), which suggested one of the urea moieties resided within close proximity to R76; however, this result also indicated that for this interaction to occur the ionic moiety must be relatively small (e.g., 18 vs $13 b$ and 13c) (Table 2). Nonetheless, with the exception of $\mathbf{1 8}$ and $\mathbf{8 e}$, a biological evaluation of this fourth series of compounds indicated that an amide moiety was required with compounds 15a-f exhibiting $\leq 43 \%$ inhibition. Additionally, the dual nitrogen atoms of the urea moiety appear to be essential for activity with the removal of either the nitrogen $\alpha-16$ or $\gamma-19$ to the aromatic ring (relative to 10a), resulting in a 27 or $15 \%$ reduction of NusB-NusE PPI inhibition, respectively. This inference was supported by the acetimidamide $\mathbf{2 1}$ being devoid of activity and the reduced activity of 7e. A further bioisosteric replacement of the oxygen 10e with sulfur, 17, abolished activity. However, installation of mono-aminoguanidine $\mathbf{2 2}$ or carboxylic acid $\mathbf{1 8}$ afforded a similar binding inhibition to lead compound 1.

Having established SAR data based on the four focused libraries developed herein, we evaluated analogues with $>50 \%$ inhibition in the NusB-NusE binding ELISA as potential inhibitors of bacterial growth. As outlined in Table 4, B. subtilis and E. coli were used as representative Gram-positive and Gram-negative species, respectively.

Pleasingly, all compounds in this analysis exhibited some level of bacterial growth inhibition ranging from mild to excellent at $200 \mu \mathrm{M}$ across both E. coli and B. subtilis or against a single species. Analogues 1 and $10 \mathrm{~g}$ exhibited selective inhibition of E. coli at 17 and 19\%, respectively. Compound 10a selectively inhibited the growth of B. subtilis at $31 \%$. Notably, 
Table 2. Inhibition of NusB-NusE Binding Interaction by 10e, 10j, 10k, and $13 \mathrm{~g}-\mathrm{i}$ at $25 \mu \mathrm{M}$ Compound Concentration Using an ELISA

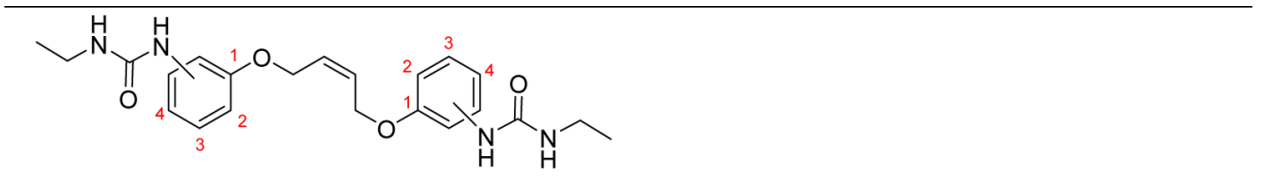

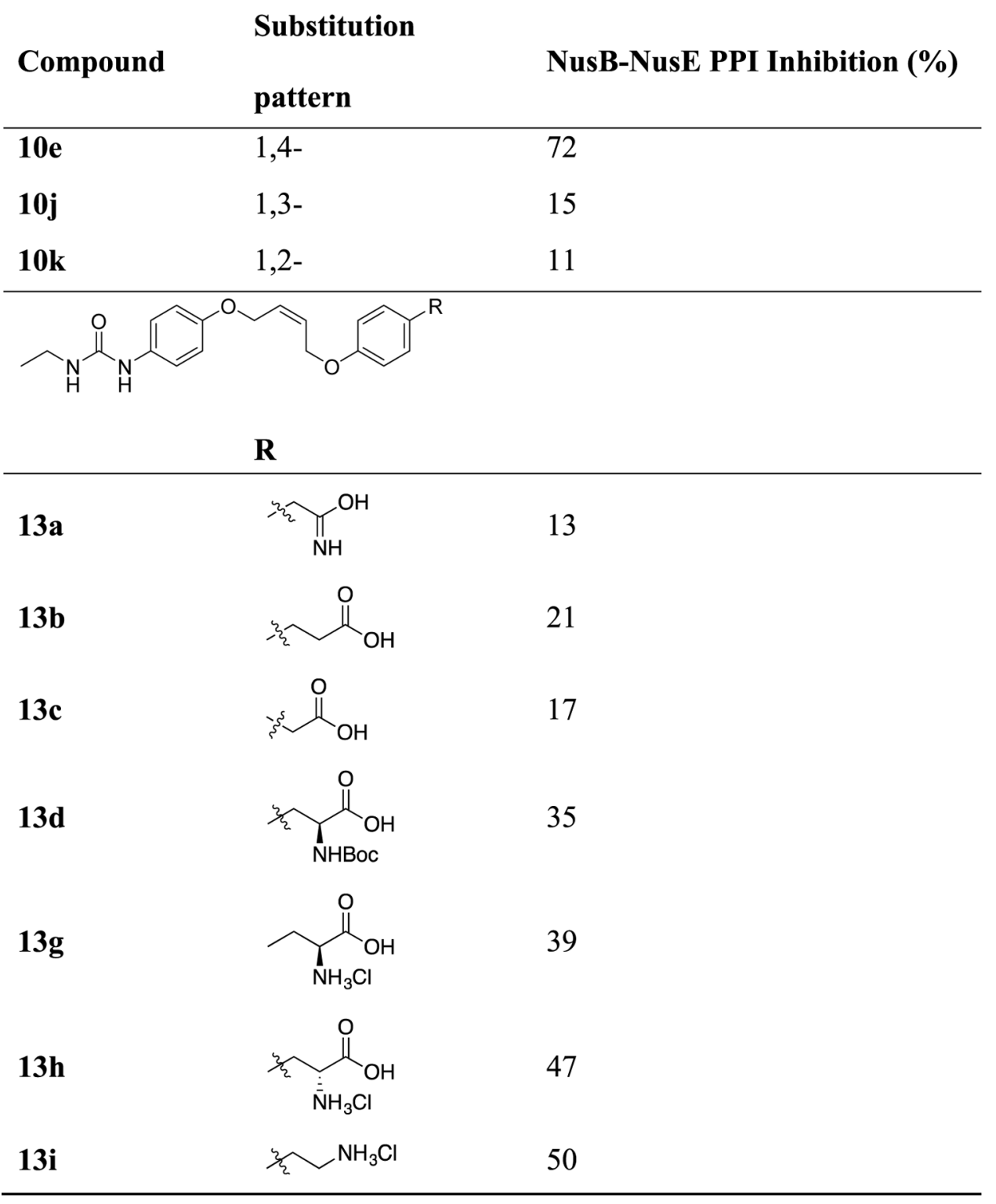

the incorporation of a cis-butene linker with $8 \mathbf{e}, 10 \mathbf{1}, 13 \mathbf{i}, 16$, 18, and 22 resulted in an antibacterial activity against both Gram-positive and Gram-negative organisms. Of the analogues evaluated herein, 22 showed the greatest activity with 100\% inhibition against both B. subtilis and E. coli. Although our ELISA evaluation of these analogues showed promising levels of inhibition of the NusB-NusE PPI, the use of these compounds in bacteria screen reveals a poor correlation between ELISA and phenotypic outcomes, which is most probably a consequence of either a poor uptake or a rapid efflux of these compounds.

As our initial lead $\mathbf{1}$ has been predicted (but not demonstrated) to be hepatotoxic, ${ }^{33}$ we examined a number of analogues in a panel of 11 cancer and 1 normal cell lines.
However, we detected no cytotoxicity for our lead $\mathbf{1}$ or for the related analogues $8 \mathrm{e}, \mathbf{1 0 a}, \mathbf{1 0 b}, \mathbf{1 0 e}$, and $\mathbf{1 8}$. Toxicity, at a level comparable to the minimum inhibitory concentration (MIC) values, was noted with analogues $\mathbf{1 3} \mathbf{i}$ and $\mathbf{2 2}$ (Table 5), but after a 4-fold increase in exposure times (3-[4,5-dimethylthiazol-2-yl]-2,5-diphenyltetrazolium bromide (MTT) assay conducted over $72 \mathrm{~h}$; MIC evaluation over $18 \mathrm{~h}){ }^{34}$ It is important to recognize the difference between chronic and acute use and that this in vitro toxicity determined using human cancer cell lines is not a demonstration of in vivo toxicity. Ultimately, only in vivo evaluation will be the determinant of safety and tolerability. ${ }^{35}$

With 22 displaying a promising antibacterial activity, it was further examined against four clinically relevant Gram-positive 
Scheme 2. Reagents and Conditions ${ }^{a}$

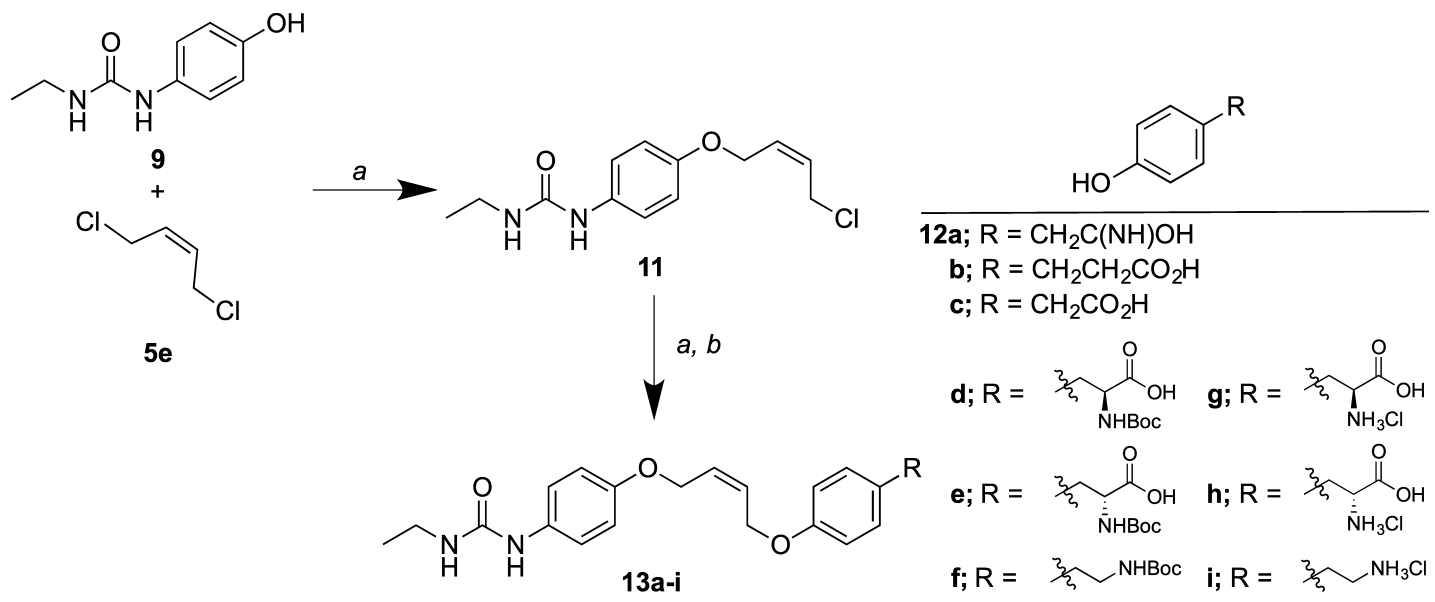

${ }^{a}$ (a) $\mathrm{Cs}_{2} \mathrm{CO}_{3}, \mathbf{1 2 a}-\mathbf{i}$, anhydrous dimethylformamide (DMF) $75^{\circ} \mathrm{C}, 2 \mathrm{~h}$; (b) $4 \mathrm{M} \mathrm{HCl}$ in dioxane, room temperature, $2 \mathrm{~h}$.

Scheme 3. Reagents and Conditions ${ }^{a}$

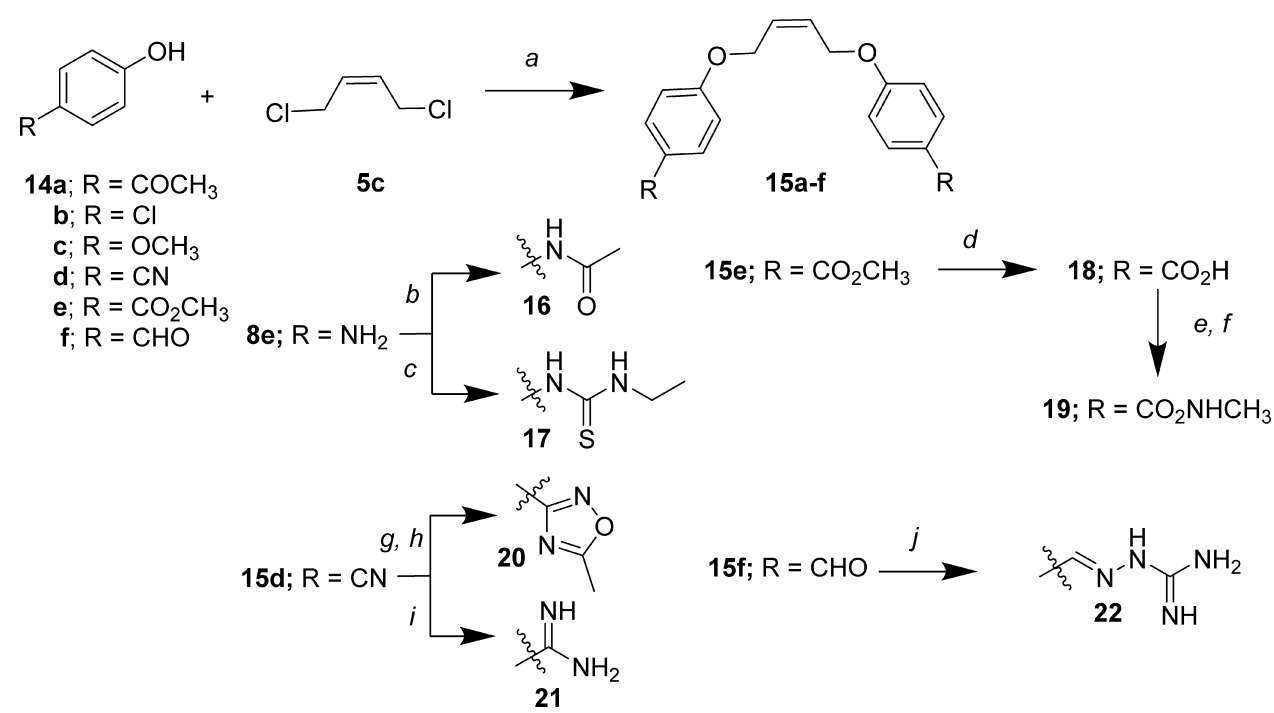

a (a) $\mathrm{K}_{2} \mathrm{CO}_{3}, \mathrm{KI}, \mathrm{CH}_{3} \mathrm{CN}$, reflux, $16 \mathrm{~h}$; (b) N,N'-diisopropylethylamine (DIPEA), acetyl chloride, anhydrous $\mathrm{CH}_{2} \mathrm{Cl}_{2}$, room temperature, 16 h; (c) ethyl isothiocyanate, triethylamine (TEA), anhydrous THF, reflux, $16 \mathrm{~h}$; (d) 10\% aq KOH/THF (2:1), reflux, $1 \mathrm{~h}$; (e) thionyl chloride, four drops of anhydrous DMF, $\mathrm{CH}_{2} \mathrm{Cl}_{2}, 40{ }^{\circ} \mathrm{C}$, $4 \mathrm{~h}$; (f) $2 \mathrm{M} \mathrm{CH}_{3} \mathrm{NH}_{2} / \mathrm{THF}$, DIPEA, room temperature, $1 \mathrm{~h}$; (g) hydroxylamine, $\mathrm{CH}_{3} \mathrm{CN}$, reflux, $4 \mathrm{~h}$; (h) acetyl chloride, $3 \AA$ molecular sieves, THF, reflux, $16 \mathrm{~h}$; (i) ammonium chloride, $2 \mathrm{M}\left(\mathrm{CH}_{3}\right)_{3} \mathrm{Al} / \mathrm{PhCH}_{3}, \mathrm{~N}_{2}, 0-80{ }^{\circ} \mathrm{C}, 16 \mathrm{~h}$; (j) aminoguanidine $\mathrm{HCl}$, cat. $10 \% \mathrm{HCl}$, ethanol, $\mu \mathrm{Wave}, 120^{\circ} \mathrm{C}, 0.5 \mathrm{~h}$.

and Gram-negative human isolates (Table 6). The MIC for 22 was determined against community-acquired methicillinresistant Staphylococcus aureus USA300 (CA-MRSA), Streptococcus pneumoniae D39, Pseudomonas aeruginosa PA14, and Acinetobacter baumannii ATCC19606.

An examination of the data presented in Table 5 shows 22 as highly potent, with an $\mathrm{MIC}$ of $\leq 3 \mu \mathrm{g} / \mathrm{mL}(7 \mu \mathrm{M})$, against both S. aureus USA300 and S. pneumoniae D39. This result is comparable to that of clinically relevant tetracycline, which has an MIC of $12-96 \mu \mathrm{g} / \mathrm{mL}$ against isolates of $S$. aureus USA300. ${ }^{36}$ In addition, 22 showed a promising activity against both $P$. aeruginosa PA14 and A. baumannii ATCC19606 with an MIC of $\leq 51 \mu \mathrm{g} / \mathrm{mL}(125 \mu \mathrm{M})$ against both isolates. Again, this promising result is comparable to the data obtained previously with penicillins, cephalosporins, and carbapenems, which have MICs of $4-16 \mu \mathrm{g} / \mathrm{mL}$ against $P$. aeruginosa. ${ }^{37}$
To confirm that compound $\mathbf{2 2}$ had a mechanism of action consistent with the inhibition of rRNA transcription through targeting the NusB-NusE interaction, epifluorescence microscopy was performed on B. subtilis strains BS23 and BS61. ${ }^{38,39}$ Strain BS23 contains a GFP fusion to the $\alpha$ subunit of the membrane-localized ATP synthase, whereas BS61 contains a GFP fusion to NusB that has a signal restricted to the subnucleoid foci that represent the sites of rRNA synthesis (Figure 5A,D, respectively). ${ }^{38,39}$ The treatment of BS23 with 22 (Figure $5 \mathrm{C}$ ) at $3 \mu \mathrm{M}(1.2 \mu \mathrm{g} / \mathrm{mL})$ had no effect on ATP synthase localization compared with colistin (Figure 5B), which caused the delocalization of the ATP synthase indicative of a membrane damage. This result confirms that $\mathbf{2 2}$ does not target the cell membranes. Furthermore, the lack of a morphological change of the cell outline or filamentation, which is indicative of the cell wall synthesis, cell division, or chromosome segregation defects, suggests that $\mathbf{2 2}$ does not affect the cytoplasmic 
Table 3. Evaluation of NusB-NusE Binding Inhibition at 25 $\mu \mathrm{M}$ Using an ELISA $6 \mathrm{e}, 7 \mathrm{e}$, and 13-21

Compound

as, no activity at $25 \mu \mathrm{M}$ compound concentration.

Table 4. Percentage Inhibition of B. subtilis and E. coli Growth by Bis-Ether Analogues 1, 8e, 10a, 10b, 10e, 10g, $13 \mathrm{i}, 16,18$, and 22 at $200 \mu \mathrm{M}$ Compound Concentration

\begin{tabular}{|c|c|c|c|c|c|}
\hline \multirow[b]{2}{*}{ compound } & \multicolumn{2}{|c|}{$\begin{array}{l}\text { percent bacterial } \\
\text { growth inhibition at } \\
200 \mu \mathrm{M}\end{array}$} & \multirow[b]{2}{*}{ compound } & \multicolumn{2}{|c|}{$\begin{array}{l}\text { percent bacterial } \\
\text { growth inhibition at } \\
200 \mu \mathrm{M}\end{array}$} \\
\hline & B. subtilis & E. coli & & B. subtilis & E. coli \\
\hline 1 & & 17 & $10 \mathrm{~g}$ & & 19 \\
\hline $8 \mathrm{e}$ & 17 & 3 & $13 i$ & 37 & 6 \\
\hline $10 a$ & 31 & & 16 & 35 & 14 \\
\hline $10 \mathrm{~b}$ & 8 & 20 & 18 & 15 & 9 \\
\hline $10 \mathrm{e}$ & 26 & 23 & 22 & 100 & 100 \\
\hline
\end{tabular}

membrane, cell wall integrity, or DNA synthesis. The treatment of BS61 (NusB-GFP) with 22 (Figure 5F) caused a significant delocalization of the NusB-GFP signal, similar to that seen with rifampicin, a known inhibitor of transcription (Figure $5 \mathrm{E}$ ). The delocalization of the NusB-GFP signal is consistent with the loss of rRNA transcriptional activity similar to that seen on the induction of the stringent response, a bacterial starvation response that results in a massive downshift of the rRNA synthesis, ${ }^{39}$ supporting the result of our modeling and ELSIA study that $\mathbf{2 2}$ is able to target the NusB-NusE interaction in live cells.

The epifluorescence microscopy data are consistent with the ability of 22 to target NusB and inhibit rRNA synthesis in live cells and support our proposed mechanism of action with $\mathbf{2 2}$. However, the cytotoxicity of 22, although not inherent within this compound class (cf. 1, 8e, 10a, 10b, and 10e, all of which inhibit the NusB-NusE PPI $>50 \%$ at $25 \mu \mathrm{M}$ and show no cytotoxicity; Table 5), suggests that that there is an additional unidentified off-target effect of this analogue.

\section{CONCLUSIONS}

A screening of our NusB-NusE pharmacophore against the mini-Maybridge compound library (56000 molecules) and a subsequent ELISA screening identified $\mathbf{1}$ as an inhibitor of the NusB-NusE PPI. Guided by the molecular modeling approaches, the subsequent development of four focused compound libraries led to the identification of 22 as a potent antibacterial agent active against clinically relevant Grampositive isolates $S$. aureus USA300 (methicillin resistant) and $S$. pneumoniae, with an MIC of $\leq 3 \mu \mathrm{g} / \mathrm{mL}$ against both strains. In addition, 22 showed a promising activity against problematic Gram-negative isolates $P$. aeruginosa PA14 and A. baumannii ATCC19606, which have proven to be difficult to treat, with an MIC of $\leq 51 \mu \mathrm{g} / \mathrm{mL}$ against both isolates. Furthermore, using epifluorescence microscopy, we demonstrated that the mode of action of $\mathbf{2 2}$ is consistent with the inhibition of the interaction of NusB with NusE, which would lead to a significant reduction in rRNA synthesis. We believe that $\mathbf{2 2}$ is a promising lead compound for the development of next-generation broadspectrum antibiotic agents, further validating the NusB-NusB protein-protein binding interaction as a potential antibacterial target. However, given the observed cytotoxicity of this analogue, a careful cytotoxicity screening for the retention of this activity should be employed in the further development of this analogue. Notwithstanding this, the lack of cytotoxicity for other analogues within this family that also displayed good levels of NusB-NusE PPI interaction, but only low levels of antibiotic activity, supports the further development of this compound class. Hence, our current focus is aimed at improving the MIC value of $\mathbf{2 2}$ and examining the antibacterial effects of subsequent analogues in other clinically problematic bacteria. This represents a new class of antitranscription antibiotic leads with activity against clinically relevant Grampositive and Gram-negative bacteria strains. As we have demonstrated an antibiotic effect that supports the inhibition of the NusB-NusE PPI, future analogues targeting this interaction should design away from any cytotoxicity liability. Notwithstanding this, an in vivo evaluation of later generations will be the ultimate determination of toxicity.

\section{EXPERIMENTAL SECTION}

Biology. Plasmid Construction. All of the cloning steps were carried out in E. coli DH5 $\alpha$ ( Table S1). The plasmids and bacterial strains used and constructed in this work were confirmed by DNA sequencing and are listed in Table S1. B. subtilis nusB was amplified using primers $5^{\prime}$-AAAGGAGATC-

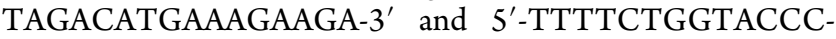
TATGATTCCC-3' from purified B. subtilis chromosomal 
Table 5. Growth Inhibition $\left(\mathrm{GI}_{50} \mu \mathrm{M}\right)$ Values of Analogues 1, 8e, 10a, 10b, 10e, 13i, 18, and 22 against a Panel of Human and Murine Cancer Cell Lines

\begin{tabular}{|c|c|c|c|c|c|c|c|c|}
\hline \multirow[b]{2}{*}{ cell line } & \multicolumn{8}{|c|}{ compound } \\
\hline & 1 & $8 \mathrm{e}$ & $10 a$ & $10 b$ & $10 \mathrm{e}$ & $13 \mathrm{i}$ & 18 & 22 \\
\hline HT29 & $>50$ & $>50$ & $>50$ & $>50$ & $>50$ & $15 \pm 0.000$ & $>50$ & $2.1 \pm 0.050$ \\
\hline U87 & $>50$ & $>50$ & $>50$ & $>50$ & $>50$ & $29 \pm 1.4$ & $>50$ & $2.0 \pm 0.10$ \\
\hline MCF-7 & $>50$ & $>50$ & $>50$ & $>50$ & $>50$ & $17 \pm 0.82$ & $>50$ & $2.3 \pm 0.10$ \\
\hline A2780 & $>50$ & $>50$ & $>50$ & $>50$ & $>50$ & $18 \pm 0.91$ & $>50$ & $2.4 \pm 0.14$ \\
\hline $\mathrm{H} 460$ & $>50$ & $>50$ & $>50$ & $>50$ & $>50$ & $21 \pm 2.1$ & $>50$ & $2.2 \pm 0.065$ \\
\hline A431 & $>50$ & $>50$ & $>50$ & $>50$ & $>50$ & $17 \pm 0.750$ & $>50$ & $2.2 \pm 0.11$ \\
\hline Du145 & $>50$ & $>50$ & $>50$ & $>50$ & $>50$ & $13 \pm 0.41$ & $>50$ & $1.7 \pm 0.12$ \\
\hline BE2-C & $>50$ & $>50$ & $>50$ & $>50$ & $>50$ & $18 \pm 3.2$ & $>50$ & $2.3 \pm 0.13$ \\
\hline SJ-G2 & $>50$ & $>50$ & $>50$ & $>50$ & $>50$ & $24 \pm 2.6$ & $>50$ & $1.8 \pm 0.048$ \\
\hline MIA & $>50$ & $>50$ & $>50$ & $>50$ & $>50$ & $28 \pm 0.82$ & $>50$ & $2.4 \pm 0.14$ \\
\hline SMA & $>50$ & $>50$ & $>50$ & $>50$ & $>50$ & $28 \pm 4.4$ & $>50$ & $2.9 \pm 0.000$ \\
\hline MCF10A & $>50$ & $>50$ & $>50$ & $>50$ & $>50$ & $19 \pm 0.50$ & $>50$ & $2.8 \pm 0.15$ \\
\hline
\end{tabular}

Table 6. MIC of Analogue $22(\mu \mathrm{g} / \mathrm{mL})$

\begin{tabular}{ccccc} 
compound & $\begin{array}{c}\text { Staphylococcus } \\
\text { aureus } \\
\text { USA300 }\end{array}$ & $\begin{array}{c}\text { Streptococcus } \\
\text { pneumonia } \\
\text { D39 }\end{array}$ & $\begin{array}{c}\text { Pseudomonas } \\
\text { aeruginosa } \\
\text { PA14 }\end{array}$ & $\begin{array}{c}\text { Acinetobacter } \\
\text { baumannii } \\
\text { ATCC19606 }\end{array}$ \\
\hline 22 & $\leq 3$ & $\leq 3$ & $\leq 51$ & $\leq 51$ \\
\hline
\end{tabular}

DNA. The nusB mutants were made by PCR splicing using mutant primers (altered bases in lower case) $5^{\prime}$ CTTTGCAGGCACTAgcTCAAATTGATGTC-3' and 5'-GACATCAATTTGAgcTAGTGCCTGCAAAG-3' (F15A); 5' GAATTGGAAGCTCGATgcGATTGCCAATG-3' and $5^{\prime}$ CATTGGCAATCgcATCGAGCTTCCAATTC-3' (R70A); and 5'-GATTGCCAATGTTGcCCGTGCGATTTTGC-3' and 5'-GCAAAATCGCACGGgCAACATTGGCAATC-3' (D75A). ${ }^{40}$ The amplicons were cut with $\mathrm{Xba \textrm {I }}$ and $A c c 65 \mathrm{I}$ and inserted into similarly cut pETMCSIII (Table S1) to produce pNG130, pNG1178, pNG1179, and pNG1180, respectively (Table S1). B. subtilis nusE was amplified using primers $5^{\prime}$ AGGAGGGTCTAGAATGGCAAAAC-3' and 5'-CTATATTTTAGGTACCAAGTTTAATTT-3' from B. subtilis chromosomal DNA and ligated into the NdeI and Acc65I sites of pNG651 to give pNG896.

Protein Overproduction and Purification. B. subtilis NusB (wild type and mutant) and NusE-GST were overproduced and purified using a similar approach to that described previ- ously. ${ }^{15,41}$ Briefly, E. coli BL21 (DE3) was transformed with one of the protein overproduction plasmids (Table S1) and cultures were grown in an autoinduction medium for $48 \mathrm{~h}$ at $25^{\circ} \mathrm{C}$. Following lysis and clarification, the NusB proteins were purified using a $1 \mathrm{~mL}$ HisTrap HP column (GE Healthcare) and the GST-tagged NusE was purified using a $1 \mathrm{~mL}$ GSTrap column (GE Healthcare). The purified proteins were dialyzed into $20 \mathrm{mM} \mathrm{KH}_{2} \mathrm{PO}_{4}, 150 \mathrm{mM} \mathrm{NaCl}, 30 \%$ glycerol, $\mathrm{pH} 7.8$, and stored at $-80{ }^{\circ} \mathrm{C}$.

ELISA. Purified full-length B. subtilis NusB was diluted to 250 $\mathrm{nM}$ in phosphate-buffered saline (PBS), and $100 \mu \mathrm{L}$ of the solution was added into NUNC Maxisorp microtitre plate wells. Following overnight incubation with the NusB solution at $4{ }^{\circ} \mathrm{C}$, the wells were washed three times with $300 \mu \mathrm{L}$ of PBS buffer and blocked with $300 \mu \mathrm{L}$ of $1 \%(\mathrm{w} / \mathrm{v})$ bovine serum albumin dissolved in PBS buffer at room temperature. After $2 \mathrm{~h}$ blocking, the plates were washed three times with a wash buffer (PBS, $0.05 \%(\mathrm{v} / \mathrm{v})$ Tween-20). The appropriate inhibitor (Tables 1-4) and $100 \mu \mathrm{L}$ of affinity-purified GST-tagged NusE at $200 \mathrm{nM}$ were incubated at $37^{\circ} \mathrm{C}$ for $15 \mathrm{~min}$, then added to each well, and incubated for $1 \mathrm{~h}$ at room temperature. Unbound NusE was removed by washing each well three times in $300 \mu \mathrm{L}$ of the wash buffer. Rabbit anti-GST primary antibody (100 $\mu \mathrm{L}, 1: 2000$ in PBS) was added to each well and incubated for $1 \mathrm{~h}$ at room temperature. After washing, goat-anti-rabbit

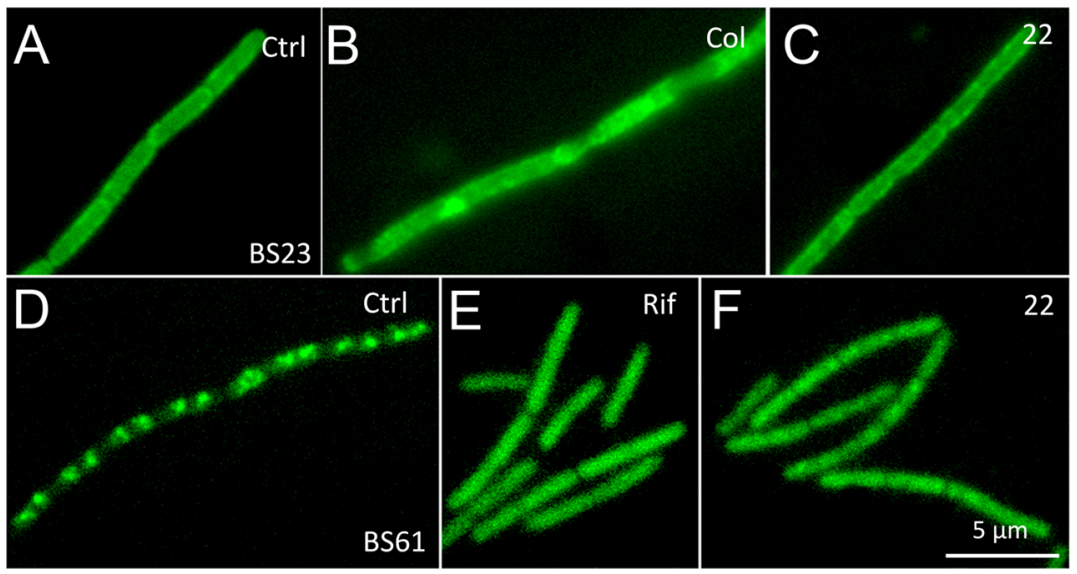

Figure 5. Epifluorescence images of B. subtilis BS23 (GFP fusion to the $\alpha$ subunit of ATP synthase: (A-C)) and BS61 (GFP fusion to NusB: (DE)). (A) Control, untreated exponentially growing BS23; (B) BS23 treated with colistin (Col); (C) treatment of BS23 with compound 22; (D) control, untreated exponentially growing BS61; (E) BS61 treated with rifampicin (rif); (F) BS61 treated with 22. 
HRP secondary antibody (1:2000 in PBS) was added to each well, incubated for $1 \mathrm{~h}$ at room temperature, and then washed three times in $300 \mu \mathrm{L}$ of the wash buffer. Visualization of PPI was achieved by adding $100 \mu \mathrm{L}$ of 3,3',5,5'-tetramethylbenzidine (liquid substrate system for ELISA, Sigma-Aldrich) to each well. The plate was incubated in a plate reader (FLUOstar Optima) at $37^{\circ} \mathrm{C}$ with $200 \mathrm{rpm}$ shaking for $6 \mathrm{~min}$. The optical density of each well was recorded at $600 \mathrm{~nm}$.

Growth Inhibition Assay. The compounds were dissolved to $50 \mathrm{mM}$ in dimethyl sulfoxide (DMSO) and serially diluted in $100 \mu \mathrm{L}$ of Luria broth (LB) to concentrations of 2.0, 1.0, 0.5, $0.25,0.125,0.0625,0.032,0.016,0.008,0.004,0.002$, and 0.001 $\mathrm{mM}$ in a 96-well NUNC MicroWell plate. Strains except $S$. pneumoniae were grown at $37^{\circ} \mathrm{C}$ in $5 \mathrm{~mL}$ of $\mathrm{LB}$ with shaking until the $\mathrm{A}_{600}$ reached $0.6-0.7 \mathrm{AU}$, and $5 \mu \mathrm{L}$ of the culture was added to each well. The plate was incubated in the plate reader (FLUOstar Optima) at $37{ }^{\circ} \mathrm{C}$ with $200 \mathrm{rpm}$ shaking. S. pneumoniae was grown in brain heart infusion (BHI) broth at $37^{\circ} \mathrm{C}$ in the presence of $5 \% \mathrm{CO}_{2}$. A $5 \mu \mathrm{L}$ of the culture at $0.6-$ $0.7 \mathrm{AU} \mathrm{A}_{600}$ was added to each well, and the plate was incubated in the plate reader at $37^{\circ} \mathrm{C}$ with shaking only for 10 $\mathrm{s}$ preceding an optical density reading. The optical density of the culture was taken every $10 \mathrm{~min}$ using $\mathrm{LB}$ or $\mathrm{BHI}$ as the blank for $16 \mathrm{~h}$ at $600 \mathrm{~nm}$. The samples were tested in triplicate, and the growth pattern of each sample was compared to that of the cells exposed to equal amounts of DMSO.

Cytotoxicity Growth Inhibition. All test agents were prepared as stock solutions $(20 \mathrm{mM})$ in DMSO and stored at $-20{ }^{\circ} \mathrm{C}$. Cell lines used in the study included MCF-7 (breast carcinoma); HT29 (colorectal carcinoma); U87, SJ-G2 (glioblastoma); SMA (murine glioblastoma); A2780 (ovarian carcinoma); H460 (lung carcinoma); A431 (skin carcinoma); Du145 (prostate carcinoma); BE2-C (neuroblastoma); and $\mathrm{MiaPaCa}-2$ (pancreatic carcinoma) and the non-cancer derived MCF10A breast cell line. All cancer cell lines were incubated in a humidified atmosphere $\left(5 \% \mathrm{CO}_{2}\right.$ at $\left.37^{\circ} \mathrm{C}\right)$ and maintained in Dulbecco's modified Eagle's medium (DMEM; Sigma, Australia) supplemented with fetal bovine serum (10\%), sodium pyruvate $(10 \mathrm{mM})$, penicillin $(100 \mathrm{IU} / \mathrm{mL})$, streptomycin $(100 \mu \mathrm{g} / \mathrm{mL})$, and L-glutamine $(4 \mathrm{mM})$. The non-cancer MCF10A cell line was cultured in DMEM:F12 (1:1) cell culture media, $5 \%$ heat inactivated horse serum, supplemented with penicillin $(50 \mathrm{IU} / \mathrm{mL})$, streptomycin $(50$ $\mu \mathrm{g} / \mathrm{mL}), 20 \mathrm{mM}$ Hepes, L-glutamine $(2 \mathrm{mM})$ epidermal growth factor $(20 \mathrm{ng} / \mathrm{mL})$, hydrocortisone $(500 \mathrm{ng} / \mathrm{mL})$, cholera toxin $(100 \mathrm{ng} / \mathrm{mL})$, and insulin $(10 \mu \mathrm{g} / \mathrm{mL})$. Growth inhibition was determined by plating cells in duplicate in medium $(100 \mu \mathrm{L})$ at a density of 2500-4000 cells per well in 96-well plates. On day 0 (24 h after plating), when the cells are in logarithmic growth, medium $(100 \mu \mathrm{L})$ with or without the test agent was added to each well. After a $72 \mathrm{~h}$ drug exposure, growth inhibitory effects were evaluated using the MTT assay and the absorbance was read at $540 \mathrm{~nm}$. An eight-point dose-response curve was produced, from which the $\mathrm{GI}_{50}$ value was calculated, representing the drug concentration at which the cell growth was inhibited by $50 \%$ on the basis of the difference between the optical density values on day 0 and those at the end of drug exposure. $^{34}$

Microscopy. B. subtilis strains BS23 (atpA-gfp) ${ }^{38}$ and BS61 $(n u s B-g f p)^{39}$ were grown in LB medium at $37^{\circ} \mathrm{C}$ with shaking until $\mathrm{OD}_{600}$ becomes $\sim 0.5$. At this point, $2 \mathrm{~mL}$ of aliquots were transferred to $15 \mathrm{~mL}$ tubes, antibiotics/compounds were added (5 $\mu \mathrm{g} / \mathrm{mL}$ rifampicin, $10 \mu \mathrm{g} / \mathrm{mL}$ colistin, or $1.2 \mu \mathrm{g} / \mathrm{mL} \mathrm{22}$ ), and the cultures were incubated with shaking for a further 30 $\mathrm{min}$. The cells were then imaged by epifluorescence microscopy as detailed. ${ }^{15}$

Molecular Modeling. Molecular docking was performed using the docking engine of MOE software (MOE, Montreal, QC, Canada) "MOE-Dock" with "Triangle Matcher" as the ligand placement method. The docked poses were refined using our reported pharmacophore and re-ranked. The highest ranked pose was exported to Accelrys Discovery Studio software. Water and axillary molecules were omitted, and the structure was typed with CHARMM force field and subjected to the implemented standard molecular dynamics cascade (two steps of energy minimization using steepest decent and conjugate gradient methods, heating to $300 \mathrm{~K}$ and equilibration for $100 \mathrm{ps}$ ). An in vacuo energy minimization procedure was performed. The production phase for the equilibrated system was run for $2 \mathrm{~ns}$ at $300 \mathrm{~K}$. The obtained model was analyzed for potential interaction using MOE-LigX module.

Chemistry. General Methods. All reagents were purchased from Sigma-Aldrich, AK Scientific, Matrix Scientific, or Lancaster Synthesis and used without purification. All solvents were redistilled from glass before use.

${ }^{1} \mathrm{H}$ and ${ }^{13} \mathrm{C}$ NMR spectra were recorded on a Bruker Avance AMX 400 spectrometer at 400.13 and $100.62 \mathrm{MHz}$, respectively, and an Advance AMX 600 spectrometer at 600.21 and $150.92 \mathrm{MHz}$, respectively. Chemical shifts $(\delta)$ are reported in parts per million (ppm) measured relative to the internal standards. Coupling constants $(J)$ are expressed in hertz $(\mathrm{Hz})$. Mass spectra were recorded on a Shimadzu LCMS 2010 EV spectrometer and an Agilent 6100 series single quadrupole LCMS system using a mobile phase of 1:1 acetonitrile $/ \mathrm{H}_{2} \mathrm{O}$ with $0.1 \%$ formic acid. Samples analyzed by Mass Spectrometry User Resource \& Research Facility (MSURRF), University of Wollongong, Australia, for highresolution mass spectrometry (HRMS) analytical HPLC traces were obtained using a Shimadzu system possessing an SIL-20A autosampler, dual LC-20AP pumps, CBM-20A bus module, CTO-20A column heater, and a SPD-20A UV/vis detector. This system was fitted with an Alltima $\mathrm{C}_{18} 5 \mu \mathrm{m} 150 \mathrm{~mm} \times 4.6$ $\mathrm{mm}$ column with solvent A $(0.06 \%$ trifluoroacetic acid (TFA) in water) and solvent $\mathrm{B}\left(0.06 \%\right.$ TFA in $\left.\mathrm{CH}_{3} \mathrm{CN}-\mathrm{H}_{2} \mathrm{O}\right)$ (90:10). In each case, HPLC traces were acquired at a flow rate of $2.0 \mathrm{~mL} \mathrm{~min} \mathrm{mi}^{-1}$ and gradient $10-100(\% \mathrm{~B})$, over $15.0 \mathrm{~min}$, with detections at 220 and $254 \mathrm{~nm}$. All samples returned satisfactory analyses. The compound purity was confirmed by a combination of LC-MS (HPLC), micro-, and/or highresolution mass spectrometry and NMR analysis. All analogues are $\geq 95 \%$ pure.

Melting points were recorded on a Büchi Melting Point M565 instrument. IR spectra were recorded on a PerkinElmer Spectrum Two FTIR Spectrometer with the UATR accessories. Thin-layer chromatography (TLC) was performed on Merck $60 \mathrm{~F} 254$ precoated aluminum plates with a thickness of $0.2 \mathrm{~mm}$. Column chromatography was performed under "flash" conditions on Merck silica gel 60 (230-400 mesh).

1,3-Bis(4-nitrophenoxy)propane (6a). General Procedure 1: A suspension of 4-nitrophenol (2) (1.516 g, $10.900 \mathrm{mmol}), 1,3$ dibromopropane (5a) $(0.500 \mathrm{~mL}, 4.953 \mathrm{mmol})$, cesium carbonate $(3.55 \mathrm{~g}, 10.900 \mathrm{mmol})$, and potassium iodide $(1.809 \mathrm{~g}, 10.900 \mathrm{mmol})$ in acetonitrile $(50 \mathrm{~mL})$ was heated at reflux for $16 \mathrm{~h}$. The resulting reaction mixture was then cooled to room temperature, concentrated in vacuo, and diluted with ethyl acetate $(50 \mathrm{~mL})$. The solution was washed 
with $1 \mathrm{M} \mathrm{NaOH}(2 \times 50 \mathrm{~mL})$ and water $(50 \mathrm{~mL})$. The organic layer was dried over $\mathrm{MgSO}_{4}$ and concentrated in vacuo. The crude solid was then recrystallized from 1:1 EtOAc/ $\mathrm{CH}_{3} \mathrm{OH}$ to afford the title compound $(1.08 \mathrm{~g}, 96 \%)$ as a white needle-like crystal (mp $\left.210-211^{\circ} \mathrm{C}\right) .{ }^{42}$

${ }^{1} \mathrm{H}$ NMR (400 MHz, DMSO- $\left.d_{6}\right) \delta 8.21(\mathrm{~d}, J=9.3 \mathrm{~Hz}, 4 \mathrm{H})$, $7.18(\mathrm{~d}, J=9.3 \mathrm{~Hz}, 4 \mathrm{H}), 4.31(\mathrm{t}, J=6.2 \mathrm{~Hz}, 4 \mathrm{H}), 2.27(\mathrm{p}, J=$ $6.2 \mathrm{~Hz}, 2 \mathrm{H})$;

${ }^{13} \mathrm{C}$ NMR (101 MHz, DMSO- $\left.d_{6}\right) \delta 164.2,141.3,126.3$, 115.5, 65.7, 28.5;

LRMS $\left(\mathrm{ESI}^{-}\right) \mathrm{m} / z: 363(\mathrm{M}-\mathrm{H}+\mathrm{HCOOH}, 100 \%), 353$ $(\mathrm{M}+\mathrm{Cl}, 25 \%)$.

1,5-Bis(4-nitrophenoxy)pentane (6b). Compound $\mathbf{6 b}$ was synthesized using general procedure 1 from 4-nitrophenol (2) $(1.330 \mathrm{~g}, 9.570 \mathrm{mmol}), 1,5$-dibromopentane $(\mathbf{5 b})(0.600 \mathrm{~mL}$, $4.350 \mathrm{mmol})$, cesium carbonate $(3.120 \mathrm{~g}, 9.570 \mathrm{mmol})$, and potassium iodide $(1.500 \mathrm{~g}, 9.570 \mathrm{mmol})$ in acetonitrile (50 $\mathrm{mL})$ to afford the title compound $(1.107 \mathrm{~g}, 89 \%)$ as a white needle-like crystal $\left(\mathrm{mp} 102-103{ }^{\circ} \mathrm{C}\right) .{ }^{42}$

${ }^{1} \mathrm{H}$ NMR (400 MHz, DMSO- $\left.d_{6}\right) \delta 8.20(\mathrm{~d}, J=9.2 \mathrm{~Hz}, 4 \mathrm{H})$, $7.14(\mathrm{~d}, J=9.3 \mathrm{~Hz}, 4 \mathrm{H}), 4.16(\mathrm{t}, J=6.4 \mathrm{~Hz}, 4 \mathrm{H}), 1.88-1.79$ $(\mathrm{m}, 4 \mathrm{H}), 1.63-1.54(\mathrm{~m}, 2 \mathrm{H})$;

${ }^{13} \mathrm{C}$ NMR (101 MHz, DMSO- $\left.d_{6}\right) \delta 164.4,141.1,126.3$, 115.4, 68.9, 28.4, 22.3;

LRMS $\left(\mathrm{ESI}^{-}\right) \mathrm{m} / z: 391(\mathrm{M}-\mathrm{H}+\mathrm{HCOOH}, 100 \%), 381$ $(\mathrm{M}+\mathrm{Cl}, 27 \%)$.

1,7-Bis(4-nitrophenoxy)heptane (6c). Compound 6c was synthesized using general procedure 1 from 4-nitrophenol (2) (0.594 g, $4.270 \mathrm{mmol})$, 1,5-dibromoheptane $(5 \mathrm{c})(0.330 \mathrm{~mL}$, $1.940 \mathrm{mmol})$, cesium carbonate $(1.391 \mathrm{~g}, 4.270 \mathrm{mmol})$, and potassium iodide $(0.709 \mathrm{~g}, 4.270 \mathrm{mmol})$ in acetonitrile (50 $\mathrm{mL})$ to afford the title compound $(0.539 \mathrm{~g}, 74 \%)$ as a white solid (mp $\left.117-119^{\circ} \mathrm{C}\right)$. $^{43}$

${ }^{1} \mathrm{H}$ NMR (400 MHz, DMSO-d $\left.)_{6}\right) \delta .19(\mathrm{~d}, J=9.1 \mathrm{~Hz}, 4 \mathrm{H})$, $7.13(\mathrm{~d}, J=9.1 \mathrm{~Hz}, 4 \mathrm{H}), 4.12(\mathrm{t}, J=6.4 \mathrm{~Hz}, 4 \mathrm{H}), 1.84-1.67$ (m, 4H), 1.42 (bs, 6H);

${ }^{13} \mathrm{C}$ NMR (101 MHz, DMSO- $\left.d_{6}\right) \delta 164.5,141.1,126.4$, 115.4, 69.0, 28.8, 28.8, 25.7;

LRMS $\left(\mathrm{ESI}^{-}\right) \mathrm{m} / z: 419(\mathrm{M}-\mathrm{H}+\mathrm{HCOOH}, 100 \%), 409$ $(\mathrm{M}+\mathrm{Cl}, 60 \%)$.

1,3-Bis(4-aminophenoxy)propane (8a). General Procedure 2: A solution of 1,3-bis(4-nitrophenoxy)propane (6a) (0.100 g, $0.314 \mathrm{mmol})$ in 1,4-dioxane $(60 \mathrm{~mL})$ was recirculated through the ThalesNano H-cube equipped with a $70 \mathrm{~mm}$ Raney nickel catalyst $\left(0.5 \mathrm{~mL} \mathrm{~min}^{-1}, 100 \% \mathrm{H}_{2}, 50 \mathrm{bar}, 50{ }^{\circ} \mathrm{C}\right)$. The reaction was monitored by TLC (1:1 EtOAc/hexane). Following the consumption of the starting material (one cycle), the reaction mixture was concentrated in vacuo to afford the title compound $(0.078 \mathrm{~g}, 96 \%)$ as a yellow solid $\left(\mathrm{mp} 108-109^{\circ} \mathrm{C}\right) .{ }^{42}$

${ }^{1} \mathrm{H}$ NMR (400 MHz, $\mathrm{CDCl}_{3}$ ) $\delta 6.77-6.70(\mathrm{~m}, 4 \mathrm{H}), 6.67-$ $6.59(\mathrm{~m}, 4 \mathrm{H}), 4.06(\mathrm{t}, J=6.2 \mathrm{~Hz}, 4 \mathrm{H}), 2.17(\mathrm{p}, J=6.2 \mathrm{~Hz}, 2 \mathrm{H})$;

${ }^{13} \mathrm{C}$ NMR $\left(101 \mathrm{MHz}, \mathrm{CDCl}_{3}\right) \delta 152.1,140.0,116.4,115.7$, 65.3, 29.6;

LRMS $\left(\mathrm{ESI}^{+}\right) m / z: 259(\mathrm{M}+\mathrm{H}, 100 \%)$.

1,5-Bis(4-aminophenoxy)pentane (8b). Compound $\mathbf{8 b}$ was synthesized using general procedure 2 from 1,5-bis(4nitrophenoxy)pentane (6b) (0.200 g, $0.577 \mathrm{mmol})$ in 1,4dioxane $(15 \mathrm{~mL})$ to afford the title compound $(0.160 \mathrm{~g}, 97 \%)$ as a yellow solid $\left(\mathrm{mp} 74-76^{\circ} \mathrm{C}\right) .^{42}$

${ }^{1} \mathrm{H}$ NMR (400 MHz, DMSO- $\left.d_{6}\right) \delta 6.63(\mathrm{~d}, J=8.8 \mathrm{~Hz}, 4 \mathrm{H})$, $6.49(\mathrm{~d}, J=8.8 \mathrm{~Hz}, 4 \mathrm{H}), 4.56(\mathrm{~s}, 4 \mathrm{H}), 3.82(\mathrm{t}, J=6.4 \mathrm{~Hz}, 4 \mathrm{H})$, $1.76-1.61(\mathrm{~m}, 4 \mathrm{H}), 1.55-1.45(\mathrm{~m}, 2 \mathrm{H})$;
${ }^{13} \mathrm{C}$ NMR (101 MHz, DMSO) $\delta 150.5,142.8,115.8,115.4$, 68.3, 29.2, 22.8;

LRMS $\left(\mathrm{ESI}^{+}\right) m / z: 287(\mathrm{M}+\mathrm{H}, 100 \%)$.

1,7-Bis(4-aminophenoxy)heptane (8c). Compound $8 \mathrm{c}$ was synthesized using general procedure 2 from 1,7-bis(4nitrophenoxy)butane $(6 \mathrm{c})$ in 1,4-dioxane $(20 \mathrm{~mL})$ to afford the title compound $(0.215 \mathrm{~g}, 95 \%)$ as a yellow solid ( $\mathrm{mp} 78-$ $\left.79.5^{\circ} \mathrm{C}\right) .{ }^{44}$

${ }^{1} \mathrm{H}$ NMR (400 MHz, $\left.\mathrm{CDCl}_{3}\right) \delta 6.82-6.67(\mathrm{~m}, 4 \mathrm{H}), 6.67-$ $6.54(\mathrm{~m}, 4 \mathrm{H}), 3.87(\mathrm{t}, J=6.5 \mathrm{~Hz}, 4 \mathrm{H}), 1.87-1.66(\mathrm{~m}, 4 \mathrm{H})$, $1.55-1.34(\mathrm{~m}, 6 \mathrm{H})$;

${ }^{13} \mathrm{C} \mathrm{NMR}\left(101 \mathrm{MHz}, \mathrm{CDCl}_{3}\right) \delta 152.4,139.4,116.5,115.8$, 68.7, 29.5, 29.3, 26.1;

LRMS $\left(\mathrm{ESI}^{+}\right) \mathrm{m} / z: 315(\mathrm{M}+\mathrm{H}, 100 \%)$.

$N, N^{\prime}$-[1,3-Propanediylbis(oxy-4,1-phenylene)]bis( $N$-ethyl)urea (10a). General Procedure 3: A suspension of 1,3-bis(4aminophenoxy)propane (8a) (0.090 g, $0.314 \mathrm{mmol})$ and ethyl isocyanate $(0.05 \mathrm{~g}, 0.691 \mathrm{mmol})$ in anhydrous THF $(50 \mathrm{~mL})$ was heated at reflux for $16 \mathrm{~h}$. The resulting reaction mixture was cooled to room temperature, and the precipitate was collected and washed with diethyl ether $(50 \mathrm{~mL})$ to afford the title compound $(0.032 \mathrm{~g}, 25 \%)$ as a cream solid (mp 211-212 $\left.{ }^{\circ} \mathrm{C}\right)$.

${ }^{1} \mathrm{H}$ NMR (400 MHz, DMSO- $\left.d_{6}\right) \delta 8.20(\mathrm{~s}, 2 \mathrm{H}), 7.26(\mathrm{~d}, J=$ $9.0 \mathrm{~Hz}, 4 \mathrm{H}), 6.82(\mathrm{~d}, J=9.0 \mathrm{~Hz}, 4 \mathrm{H}), 4.04(\mathrm{t}, J=6.3 \mathrm{~Hz}, 4 \mathrm{H})$, $3.13-3.01(\mathrm{~m}, 4 \mathrm{H}), 2.13-2.02(\mathrm{~m}, 4 \mathrm{H}), 1.03(\mathrm{t}, J=7.2 \mathrm{~Hz}$, $6 \mathrm{H})$.

${ }^{13} \mathrm{C}$ NMR (101 MHz, DMSO-d $\left.d_{6}\right) \delta 155.8,153.5,134.3$, 119.8, 115.0, 64.8, 34.4, 29.2, 16.0;

LRMS $\left(\mathrm{ESI}^{+}\right) \mathrm{m} / z: 401(\mathrm{M}+\mathrm{H}, 100 \%)$;

HRMS (ESI ${ }^{+}$): Calcd 401.2189 for $\mathrm{C}_{21} \mathrm{H}_{29} \mathrm{~N}_{4} \mathrm{O}_{0}[\mathrm{M}+\mathrm{H}]^{+}$; found, 401.2196.

$N, N^{\prime}$-[1,5-Pentanediylbis(oxy-4,1-phenylene)]bis( $N$-ethyl)urea (10b). Compound $10 \mathrm{~b}$ was synthesized using general procedure 3 from 1,5-bis(4-aminophenoxy)pentane (8b) $(0.200 \mathrm{~g}, 0.700 \mathrm{mmol})$ and ethyl isocyanate $(0.11 \mathrm{~mL}, 1.540$ $\mathrm{mmol})$ in THF $(50 \mathrm{~mL})$ to afford the title compound $(0.100 \mathrm{~g}$, $33 \%)$ as an off-white solid ( $\mathrm{mp} 203-205^{\circ} \mathrm{C}$ ).

${ }^{1} \mathrm{H}$ NMR (400 MHz, DMSO- $d_{6}$ ) $\delta 8.16(\mathrm{~s}, 2 \mathrm{H}), 7.25$ (d, $J=$ $9.0 \mathrm{~Hz}, 4 \mathrm{H}), 6.79(\mathrm{~d}, J=9.0 \mathrm{~Hz}, 4 \mathrm{H}), 6.00-5.89(\mathrm{~m}, 2 \mathrm{H}), 3.90$ $(\mathrm{t}, J=6.4 \mathrm{~Hz}, 4 \mathrm{H}), 3.08(\mathrm{dq}, J=7.1,5.6 \mathrm{~Hz}, 4 \mathrm{H}), 1.81-1.63$ (m, 4H), 1.60-1.45 (m, 2H), $1.03(\mathrm{t}, J=7.2 \mathrm{~Hz}, 6 \mathrm{H})$;

${ }^{13} \mathrm{C}$ NMR (101 MHz, DMSO-d $\left.d_{6}\right) \delta 155.4,153.2,133.6$, 119.3, 114.5, 67.5, 33.9, 28.5, 22.3, 15.5;

LRMS $\left(\mathrm{ESI}^{+}\right) \mathrm{m} / z: 429(\mathrm{M}+\mathrm{H}, 100 \%)$;

HRMS $\left(\mathrm{ESI}^{+}\right)$: Calcd 429.2502 for $\mathrm{C}_{23} \mathrm{H}_{33} \mathrm{~N}_{4} \mathrm{O}_{4}[\mathrm{M}+\mathrm{H}]^{+}$; found, 429.2596.

$N, N^{\prime}$-[1,7-Heptanediylbis(oxy-4,1-phenylene)]bis( $N$-ethyl)urea (10c). Compound 10c was synthesized using general procedure 3 from 1,7-bis(4-aminophenoxy)heptane (8c) $(0.270 \mathrm{~g}, 0.859 \mathrm{mmol})$ and ethyl isocyanate $(0.15 \mathrm{~mL}, 1.891$ $\mathrm{mmol})$ in THF $(50 \mathrm{~mL})$ to afford the title compound $(0.077 \mathrm{~g}$, $23 \%)$ as an off-white solid ( $\left.\mathrm{mp} 187-189^{\circ} \mathrm{C}\right)$.

${ }^{1} \mathrm{H}$ NMR (400 MHz, DMSO- $\left.d_{6}\right) \delta 8.18(\mathrm{~s}, 2 \mathrm{H}), 7.25$ (d, $J=$ $8.9 \mathrm{~Hz}, 4 \mathrm{H}), 6.78(\mathrm{~d}, J=8.9 \mathrm{~Hz}, 4 \mathrm{H}), 5.98-5.95(\mathrm{~m}, 2 \mathrm{H}), 3.88$ $(\mathrm{t}, J=6.4 \mathrm{~Hz}, 4 \mathrm{H}), 3.12-3.05(\mathrm{~m}, 4 \mathrm{H}), 1.75-1.58(\mathrm{~m}, 4 \mathrm{H})$, $1.39(\mathrm{~s}, 6 \mathrm{H}), 1.03(\mathrm{t}, J=7.2 \mathrm{~Hz}, 6 \mathrm{H})$;

${ }^{13} \mathrm{C}$ NMR (101 MHz, DMSO- $\left.d_{6}\right) \delta 155.9,153.7,134.1$, 119.8, 115.0, 68.0, 34.4, 29.2, 29.0, 26.0, 16.0;

LRMS $\left(\mathrm{ESI}^{-}\right) \mathrm{m} / z: 501(\mathrm{M}+\mathrm{HCOOH}(-\mathrm{H}), 100 \%)$;

HRMS (ESI ${ }^{+}$): Calcd 457.2815 for $\mathrm{C}_{25} \mathrm{H}_{37} \mathrm{~N}_{4} \mathrm{O}_{4}[\mathrm{M}+\mathrm{H}]^{+}$; found, 457.2831 . 
Di-tert-butyl(((oxybis(ethane-2,1-diyl))bis(oxy))bis(4,1phenylene))dicarbamate (7d). General Procedure 4: A suspension of tert-butyl(4-hydroxyphenyl)carbamate (3) $(0.570 \mathrm{~g}, 2.660 \mathrm{mmol})$ and cesium carbonate $(0.990 \mathrm{~g}, 3.030$ $\mathrm{mmol})$ in acetonitrile $(50 \mathrm{~mL})$ was stirred for $10 \mathrm{~min}$, before the portionwise addition of diethylene glycol di $(p$-toluenesulfonate) (5d) $(0.500 \mathrm{~g}, 1.210 \mathrm{mmol})$. The mixture was then stirred at room temperature for $16 \mathrm{~h}$. The resulting mixture was concentrated in vacuo and diluted with ethyl acetate $(50 \mathrm{~mL})$. The solution was washed with water $(2 \times 50 \mathrm{~mL})$ and $1 \mathrm{M}$ sodium hydroxide $(50 \mathrm{~mL})$. The organic layer was dried over magnesium sulfate and concentrated in vacuo to afford the title compound $(0.545 \mathrm{~g}, 92 \%)$ as an off-white solid (mp 146-153 $\left.{ }^{\circ} \mathrm{C}\right)$.

${ }^{1} \mathrm{H}$ NMR (400 MHz, acetone- $d_{6}$ ) $\delta 8.18$ (s, 2H, NH), 7.44 $(\mathrm{d}, J=8.8 \mathrm{~Hz}, 4 \mathrm{H}), 6.98-6.68(\mathrm{~m}, 4 \mathrm{H}), 4.25-4.08(\mathrm{~m}, 4 \mathrm{H})$, $3.98-3.81(\mathrm{~m}, 4 \mathrm{H}), 1.47(\mathrm{~s}, 18 \mathrm{H})$;

${ }^{13} \mathrm{C}$ NMR (101 MHz, DMSO- $\left.d_{6}\right) \delta 153.6,152.9,132.7$, 119.7, 114.5, 78.6, 69.1, 67.3, 28.2;

LRMS $\left(\mathrm{ESI}^{-}\right) m / z: 533(\mathrm{M}+\mathrm{HCOOH}(-\mathrm{H}), 40 \%), 413$ (100\%);

HRMS $\left(\mathrm{ESI}^{+}\right)$: Calcd 489.2601 for $\mathrm{C}_{26} \mathrm{H}_{37} \mathrm{~N}_{2} \mathrm{O}_{7}[\mathrm{M}+\mathrm{H}]^{+}$; found, 489.2514 .

Di-tert-butyl((but-2-ene-1,4-diylbis(oxy))bis(4,1phenylene))(Z)-dicarbamate (7e). Compound $7 \mathrm{e}$ was synthesized using general procedure 4 from tert-butyl(4hydroxyphenyl)carbamate (3) $(0.870 \mathrm{~g}, 4.160 \mathrm{mmol})$, cesium carbonate $(1.360 \mathrm{~g}, 4.160 \mathrm{mmol})$, and (Z)-1,4-dichloro-2butene $(5 \mathbf{e})(0.125 \mathrm{~mL}, 1.890 \mathrm{mmol})$ in acetonitrile $(50 \mathrm{~mL})$ to afford the title compound $(0.400 \mathrm{~g}, 45 \%)$ an off-white solid (mp $\left.139-145^{\circ} \mathrm{C}\right)$.

${ }^{1} \mathrm{H}$ NMR (400 MHz, acetone- $\left.d_{6}\right) \delta 8.19(\mathrm{~s}, 2 \mathrm{H}), 7.45(\mathrm{~d}, J=$ $8.8 \mathrm{~Hz}, 4 \mathrm{H}), 6.90(\mathrm{~d}, J=9.0 \mathrm{~Hz}, 2 \mathrm{H}), 5.88(\mathrm{t}, J=3.4 \mathrm{~Hz}, 2 \mathrm{H})$, $4.73(\mathrm{~d}, J=4.1 \mathrm{~Hz}, 4 \mathrm{H}), 1.47(\mathrm{~s}, 18 \mathrm{H})$;

${ }^{13} \mathrm{C}$ NMR (101 MHz, DMSO- $\left.d_{6}\right) \delta$ 153.8, 153.4, 133.2, 128.9, 120.1, 115.1, 79.1, 66.8, 28.6;

LRMS $\left(\mathrm{ESI}^{-}\right) \mathrm{m} / z: 515(\mathrm{M}+\mathrm{FA}-\mathrm{H}, 55 \%), 395$ (100);

HRMS (ESI ${ }^{+}$): Calcd 493.2309 for $\mathrm{C}_{26} \mathrm{H}_{34} \mathrm{~N}_{2} \mathrm{O}_{6} \mathrm{Na}[\mathrm{M}+$ $\mathrm{Na}]^{+}$; found, 493.2298.

Di-tert-butyl((but-2-ene-1,4-diylbis(oxy))bis(4,1phenylene))(E)-dicarbamate (7f). Compound $7 f$ was synthesized using general procedure 4 from tert-butyl(4hydroxyphenyl)carbamate (3) $(0.750 \mathrm{~g}, 3.580 \mathrm{mmol})$, cesium carbonate (1.166 g, $3.580 \mathrm{mmol})$, and $(E)$-1,4-dichloro-2butene $(\mathbf{5 f})(0.125 \mathrm{~mL}, 1.890 \mathrm{mmol})$ in acetonitrile $(50 \mathrm{~mL})$ to afford the title compound $(0.734 \mathrm{~g}, 96 \%)$ an off-white solid (mp 196-201 $\left.{ }^{\circ} \mathrm{C}\right)$.

${ }^{1} \mathrm{H}$ NMR (400 MHz, DMSO-d 6 ) $\delta 9.12(\mathrm{~s}, 2 \mathrm{H}), 7.34$ (d, $J=$ $8.4 \mathrm{~Hz}, 4 \mathrm{H}), 6.85(\mathrm{~d}, J=9.0 \mathrm{~Hz}, 4 \mathrm{H}), 6.07-5.95(\mathrm{~m}, 2 \mathrm{H})$, 4.71-4.40 (m, 4H), $1.46(\mathrm{~s}, 8 \mathrm{H})$;

${ }^{13} \mathrm{C}$ NMR (101 MHz, DMSO- $\left.d_{6}\right) \delta 153.8,153.4,133.2$, 128.9, 120.1, 115.1, 79.1, 66.8, 28.6;

LRMS $\left(\mathrm{ESI}^{-}\right) \mathrm{m} / z: 515(\mathrm{M}+\mathrm{FA}-\mathrm{H}, 55 \%), 395$ (100);

HRMS $\left(\right.$ ESI $^{+}$): Calcd 493.2309 for $\mathrm{C}_{26} \mathrm{H}_{34} \mathrm{~N}_{2} \mathrm{O}_{6} \mathrm{Na}[\mathrm{M}+$ $\mathrm{Na}]^{+}$; found, 493.2301.

1, 1'-(((Oxybis (ethane-2,1-diyl)) bis (oxy)) bis (4, 1phenylene))bis(3-ethylurea) (10d). A suspension of di-tertbutyl(( oxybis(ethane-2,1-diyl))bis(oxy))bis(4,1-phenylene))dicarbamate $(7 \mathrm{~d})(0.400 \mathrm{~g}, 0.819 \mathrm{mmol})$ in $4 \mathrm{M} \mathrm{HCl}$ in $1,4-$ dioxane $(50 \mathrm{~mL})$ was stirred for $1 \mathrm{~h}$ at room temperature. The reaction mixture was then concentrated under a stream of air overnight. The resulting precipitate was diluted with anhydrous THF $(50 \mathrm{~mL})$ and heated to reflux for over $10 \mathrm{~min}$.
Triethylamine $(0.260 \mathrm{~mL}, 1.970 \mathrm{mmol})$ and ethyl isocyanate $(0.160 \mathrm{~mL}, 1.970 \mathrm{mmol})$ were then added to the suspension, and the mixture was heated at reflux for $16 \mathrm{~h}$. The resulting reaction mixture was then concentrated in vacuo and diluted with ethyl acetate $(100 \mathrm{~mL})$. The solution was washed with water $(2 \times 100 \mathrm{~mL})$ and a saturated sodium chloride solution $(100 \mathrm{~mL})$. The organic layer was dried over magnesium sulfate and concentrated in vacuo to afford the title compound (0.204 g, 57\%) as a white solid (mp 203-207 $\left.{ }^{\circ} \mathrm{C}\right)$.

${ }^{1} \mathrm{H}$ NMR (400 MHz, DMSO- $\left.d_{6}\right) \delta 8.18(\mathrm{~s}, 2 \mathrm{H}), 7.27(\mathrm{~d}, J=$ $8.9 \mathrm{~Hz}, 4 \mathrm{H}), 6.82(\mathrm{~d}, J=8.9 \mathrm{~Hz}, 4 \mathrm{H}), 5.97(\mathrm{t}, J=5.4 \mathrm{~Hz}, 2 \mathrm{H})$, 4.13-3.97 (m, 4H), 3.87-3.66 (m, 4H), 3.14-2.99 (m, 4H), $1.04(\mathrm{t}, J=7.1 \mathrm{~Hz}, 6 \mathrm{H})$;

${ }^{13} \mathrm{C}$ NMR (101 MHz, DMSO- $\left.d_{6}\right) \delta 155.9,153.5,134.3$, $119.8,115.0,69.6,67.8,34.4,16.0$;

LRMS $\left(\mathrm{ESI}^{+}\right) \mathrm{m} / z: 431(\mathrm{M}+\mathrm{H}, 100 \%)$;

HRMS (ESI ${ }^{+}$): Calcd 431.2294 for $\mathrm{C}_{22} \mathrm{H}_{31} \mathrm{~N}_{4} \mathrm{O}_{5}[\mathrm{M}+\mathrm{H}]^{+}$; found, 431.2285.

(Z)-4,4'-(But-2-ene-1,4-diylbis(oxy))dianiline hydrochloride (8e). General Procedure 5: A suspension of di-tertbutyl((but-2-ene-1,4-diylbis(oxy))bis(4,1-phenylene $))(Z)$-dicarbamate $(7 \mathbf{e})(0.400 \mathrm{~g}, 0.819 \mathrm{mmol})$ in $4 \mathrm{M} \mathrm{HCl}$ in $1,4-$ dioxane $(50 \mathrm{~mL})$ was stirred for $1 \mathrm{~h}$ at room temperature. The reaction mixture was then concentrated under a stream of air overnight, washed with cold THF $(20 \mathrm{~mL})$, and filtered to afford the title compound $(0.183 \mathrm{~g}, 90 \%)$ as a brown solid (mp $\left.230-233{ }^{\circ} \mathrm{C}\right)$.

${ }^{1} \mathrm{H}$ NMR (400 MHz, $\left.\mathrm{CD}_{3} \mathrm{OD}\right) \delta 7.39-7.29(\mathrm{~m}, 4 \mathrm{H}), 7.18-$ $7.05(\mathrm{~m}, 4 \mathrm{H}), 6.01-5.89(\mathrm{~m}, 2 \mathrm{H}), 4.79(\mathrm{~d}, J=4.0 \mathrm{~Hz}, 4 \mathrm{H})$;

${ }^{13} \mathrm{C}$ NMR $\left(101 \mathrm{MHz}, \mathrm{CD}_{3} \mathrm{OD}\right) \delta 158.9,128.1,123.9,123.1$, 115.7, 64.3;

LRMS $\left(\mathrm{ESI}^{+}\right) m / z: 271(\mathrm{M}+\mathrm{H}, 100 \%), 312\left(\mathrm{M}+\mathrm{CH}_{3} \mathrm{CN}\right.$ $+\mathrm{H}, 30 \%)$;

HRMS $\left(\mathrm{ESI}^{+}\right.$): Calcd 271.1446 for $\mathrm{C}_{16} \mathrm{H}_{19} \mathrm{~N}_{2} \mathrm{O}_{2}[\mathrm{M}+\mathrm{H}]^{+}$; found, 271.1455 .

(E)-4,4'-(But-2-ene-1,4-diylbis(oxy))dianiline Hydrochloride (8f). Compound $8 \mathrm{f}$ was synthesized using general procedure 5 from di-tert-butyl((but-2-ene-1,4-diylbis(oxy))bis$(4,1$-phenylene $))(E)$-dicarbamate $(7 \mathbf{f})(0.500 \mathrm{~g}, 1.063 \mathrm{mmol})$ and $4 \mathrm{M} \mathrm{HCl}$ in 1,4-dioxane $(50 \mathrm{~mL})$ to afford the title compound $(0.231 \mathrm{~g}, 90 \%)$ as a brown solid (mp $105{ }^{\circ} \mathrm{C}$ (dec.))

${ }^{1} \mathrm{H}$ NMR (400 MHz, $\mathrm{CDCl}_{3}$ ) $\delta$ 6.80-6.69 (m, 4H), 6.69$6.56(\mathrm{~m}, 4 \mathrm{H}), 6.04-6.02(\mathrm{~m}, 2 \mathrm{H}), 4.48(\mathrm{dd}, J=2.4,1.1 \mathrm{~Hz}$, $4 \mathrm{H})$;

${ }^{13} \mathrm{C}$ NMR (101 MHz, DMSO- $\left.d_{6}\right) \delta 143.0,129.0,116.0$, 115.4, 68.3;

LRMS $\left(\mathrm{ESI}^{-}\right) \mathrm{m} / z: 271(\mathrm{M}+\mathrm{H}, 33 \%), 136(100 \%)$;

HRMS (ESI ${ }^{+}$): Calcd 271.1446 for $\mathrm{C}_{16} \mathrm{H}_{19} \mathrm{~N}_{2} \mathrm{O}_{2}[\mathrm{M}+\mathrm{H}]^{+}$; found, 271.1443 .

(Z)-1,1'-((But-2-ene-1,4-diylbis(oxy))bis(4,1-phenylene))bis(3-ethylurea) (10e). General Procedure 6: A solution of $(Z)$ 4,4'-(but-2-ene-1,4-diylbis(oxy))dianiline hydrochloride (8e) $(0.147 \mathrm{~g}, 0.428 \mathrm{mmol})$ and trimethylamine $(0.130 \mathrm{~mL}, 0.942$ $\mathrm{mmol})$ in anhydrous THF $(30 \mathrm{~mL})$ was stirred for $20 \mathrm{~min}$, followed by the addition of ethyl isocyanate $(0.100 \mathrm{~mL}, 0.942$ $\mathrm{mmol}$ ). The resultant mixture was then heated at reflux for $16 \mathrm{~h}$ and cooled to room temperature in vacuo to give an off-white precipitate, which was washed with water $(25 \mathrm{~mL})$ and $\mathrm{CH}_{2} \mathrm{Cl}_{2}$ $(25 \mathrm{~mL})$. The precipitate was then dried in vacuo to afford the title compound $(0.127 \mathrm{~g}, 72 \%)$ as an off-white solid (mp 210$\left.212{ }^{\circ} \mathrm{C}\right)$. 
${ }^{1} \mathrm{H}$ NMR (400 MHz, DMSO- $\left.d_{6}\right) \delta 8.19$ (s, 2H), 7.27 (d, $J=$ $8.9 \mathrm{~Hz}, 4 \mathrm{H}), 6.83(\mathrm{~d}, J=8.9 \mathrm{~Hz}, 4 \mathrm{H}), 5.97(\mathrm{t}, J=5.4 \mathrm{~Hz}, 2 \mathrm{H})$, $5.82(\mathrm{t}, J=3.2 \mathrm{~Hz}, 2 \mathrm{H}), 4.63(\mathrm{~d}, J=3.5 \mathrm{~Hz}, 4 \mathrm{H}), 3.12-3.03$ $(\mathrm{m}, 4 \mathrm{H}), 1.03(\mathrm{t}, J=7.2 \mathrm{~Hz}, 6 \mathrm{H})$;

${ }^{13} \mathrm{C}$ NMR (101 MHz, DMSO- $\left.d_{6}\right) \delta 155.8,153.1,134.5$, 129.0, 119.8, 115.2, 64.5, 34.4, 16.0;

LRMS $\left(\mathrm{ESI}^{+}\right) \mathrm{m} / z: 413(\mathrm{M}+\mathrm{H}, 100 \%)$;

HRMS $\left(\mathrm{ESI}^{+}\right)$: Calcd 413.2189 for $\mathrm{C}_{22} \mathrm{H}_{29} \mathrm{~N}_{4} \mathrm{O}_{4}[\mathrm{M}+\mathrm{H}]^{+}$; found, 413.2204.

(E)-1,1'-((But-2-ene-1,4-diylbis(oxy))bis(4,1-phenylene))bis(3-ethylurea) (10f). Compound 10f was synthesized using general procedure 6 from $(E)-4,4^{\prime}$-(but-2-ene-1,4-diylbis(oxy))dianiline hydrochloride (8f) (0.198 g, $0.732 \mathrm{mmol})$, triethylamine $(0.122 \mathrm{~mL}, 1.537 \mathrm{mmol})$, and anhydrous THF $(50 \mathrm{~mL})$ to afford the title compound $(0.156 \mathrm{~g}, 52 \%)$ as an off-white solid (mp $240{ }^{\circ} \mathrm{C}$ (dec.)).

${ }^{1} \mathrm{H}$ NMR $\left(600 \mathrm{MHz}, \mathrm{DMSO}-d_{6}\right) \delta 8.20(\mathrm{~s}, 2 \mathrm{H}), 7.27(\mathrm{~d}, J=$ $8.7 \mathrm{~Hz}, 4 \mathrm{H}), 6.82(\mathrm{~d}, J=8.7 \mathrm{~Hz}, 4 \mathrm{H}), 6.02(\mathrm{~s}, 2 \mathrm{H}), 6.00-5.94$ $(\mathrm{m}, 2 \mathrm{H}), 4.52(\mathrm{~s}, 4 \mathrm{H}), 3.14-3.01(\mathrm{~m}, 4 \mathrm{H}), 1.04(\mathrm{t}, J=7.1 \mathrm{~Hz}$, $6 \mathrm{H})$;

${ }^{13} \mathrm{C}$ NMR (101 MHz, DMSO- $\left.d_{6}\right) \delta 155.8,153.2,134.4$, 128.9, 119.8, 115.2, 67.9, 34.4, 16.0;

LRMS $\left(\mathrm{ESI}^{+}\right) \mathrm{m} / z: 413(\mathrm{M}+\mathrm{H}, 100 \%)$

HRMS (ESI ${ }^{+}$): Calcd 413.2189 for $\mathrm{C}_{22} \mathrm{H}_{29} \mathrm{~N}_{4} \mathrm{O}_{4}[\mathrm{M}+\mathrm{H}]^{+}$; found, 413.2198.

1-Ethyl-3-(4-hydroxyphenyl)urea (9). A mixture of 4aminophenol (4) (0.800 g, $7.36 \mathrm{mmol})$ and ethyl isocyanate $(0.500 \mathrm{~g}, 7.034 \mathrm{mmol})$ in anhydrous THF $(50 \mathrm{~mL})$ was then stirred at room temperature for $4 \mathrm{~h}$. The reaction mixture was the concentrated in vacuo, diluted with ether $(50 \mathrm{~mL})$, and sonicated for $2 \mathrm{~min}$. The resulting suspension was then filtered and washed with diethyl ether to afford the title compound $(1.008 \mathrm{~g}, 80 \%)$ as an off-white solid ( $\left.\mathrm{mp} 165-171{ }^{\circ} \mathrm{C}\right)$.

${ }^{1} \mathrm{H}$ NMR (400 MHz, DMSO- $\left.d_{6}\right) \delta 8.94(\mathrm{~s}, 1 \mathrm{H}), 8.04$ (s, $1 \mathrm{H}), 7.14(\mathrm{~d}, J=8.4 \mathrm{~Hz}, 2 \mathrm{H}), 6.64(\mathrm{~d}, J=8.4 \mathrm{~Hz}, 2 \mathrm{H}), 5.93(\mathrm{~s}$, $1 \mathrm{H}), 3.15-2.95(\mathrm{~m}, 2 \mathrm{H}), 1.03(\mathrm{t}, J=7.0 \mathrm{~Hz}, 3 \mathrm{H})$;

${ }^{13} \mathrm{C}$ NMR (101 MHz, acetone- $\left.d_{6}\right) \delta 155.5,152.3,132.8$, 120.3, 115.0, 34.3, 15.1;

LRMS $\left(\mathrm{ESI}^{-}\right) \mathrm{m} / z: 179(\mathrm{M}-\mathrm{H}, 100 \%)$;

HRMS (ESI ${ }^{+}$): Calcd 181.0977 for $\mathrm{C}_{9} \mathrm{H}_{13} \mathrm{~N}_{2} \mathrm{O}_{2}[\mathrm{M}+\mathrm{H}]^{+}$; found, 181.0983 .

1,1'-(((1,2-Phenylenebis(methylene))bis(oxy))bis(4, 1phenylene))bis(3-ethylurea) (10g). General Procedure 7: A suspension of 1-ethyl-3-(4-hydroxyphenyl)urea (9) (0.225 g, $1.250 \mathrm{mmol}), 1,2$-bis(bromomethyl)benzene $(5 \mathrm{~g})(0.150 \mathrm{~g}$, $0.570 \mathrm{mmol})$, cesium carbonate $(0.407,1.250 \mathrm{mmol})$, and a catalytic amount of potassium iodide in acetone $(50 \mathrm{~mL})$ was refluxed for $16 \mathrm{~h}$. The resulting reaction mixture was then concentrated to dryness, and the resulting residue was purified by flash chromatography $\left(10 \% \mathrm{CH}_{3} \mathrm{OH}\right.$ in $\left.\mathrm{CH}_{2} \mathrm{Cl}_{2}\right)$ to afford the title compound $(0.200 \mathrm{~g}, 76 \%)$ as a white solid (mp 219$220{ }^{\circ} \mathrm{C}$ ).

${ }^{1} \mathrm{H}$ NMR (400 MHz, DMSO- $d_{6}$ ) $\delta 8.21$ (brs, 2H), 7.50 (dd, $J$ $=5.5,3.5 \mathrm{~Hz}, 2 \mathrm{H}), 7.35(\mathrm{dd}, J=5.6,3.4 \mathrm{~Hz}, 2 \mathrm{H}), 7.27(\mathrm{~d}, J=$ $9.0 \mathrm{~Hz}, 4 \mathrm{H}), 6.90(\mathrm{~d}, J=9.0 \mathrm{~Hz}, 4 \mathrm{H}), 5.99$ (brs, $2 \mathrm{H}), 5.15$ (s, $4 \mathrm{H}), 3.08(\mathrm{dt}, J=7.1,5.7 \mathrm{~Hz}, 4 \mathrm{H}), 1.04(\mathrm{t}, J=7.2 \mathrm{~Hz}, 6 \mathrm{H})$;

${ }^{13} \mathrm{C}$ NMR (400 MHz, DMSO- $\left.d_{6}\right) \delta 155.8,153.2,135.9$, 134.6, 128.8, 128.3, 119.8, 115.39, 67.7, 34.4, 16.0;

LRMS $\left(\mathrm{ESI}^{+}\right) \mathrm{m} / z: 463(\mathrm{M}+\mathrm{H}, 100 \%)$;

HRMS $\left(\right.$ ESI $\left.^{+}\right)$: Calcd 463.2345 for $\mathrm{C}_{26} \mathrm{H}_{31} \mathrm{~N}_{4} \mathrm{O}_{4}[\mathrm{M}+\mathrm{H}]^{+}$; found, 463.2360 .

1,1'-(((1,3-Phenylenebis(methylene))bis(oxy))bis(4,1phenylene))bis(3-ethylurea) (10h). Compound 10h was synthesized using general procedure 7 from 1-ethyl-3-(4hydroxyphenyl)urea (9) (0.757 g, $4.200 \mathrm{mmol}), 1,3$-bis(bromomethyl)benzene $(\mathbf{5 h})(0.528 \mathrm{~g}, 2.000 \mathrm{mmol})$, potassium carbonate $(0.580 \mathrm{~g}, 4.200 \mathrm{mmol})$, and a catalytic amount of potassium iodide in acetone $(50 \mathrm{~mL})$. The resulting residue was purified by flash chromatography (10\% EtOAc in hexane) to afford the title compound $(0.318 \mathrm{~g}, 34 \%)$ as a white solid (mp 213-214 $\left.{ }^{\circ} \mathrm{C}\right)$.

${ }^{1} \mathrm{H}$ NMR (400 MHz, DMSO- $\left.d_{6}\right) \delta 8.19$ (s, 2H), 7.50 (s, $1 \mathrm{H}), 7.45-7.35(\mathrm{~m}, 3 \mathrm{H}), 7.27(\mathrm{~d}, J=9.0 \mathrm{~Hz}, 4 \mathrm{H}), 6.88$ (d, $J=$ $9.0 \mathrm{~Hz}, 4 \mathrm{H}), 5.97(\mathrm{t}, J=5.5 \mathrm{~Hz}, 2 \mathrm{H}), 5.04(\mathrm{~s}, 4 \mathrm{H}), 3.15-2.97$ $(\mathrm{m}, 4 \mathrm{H}), 1.03(\mathrm{t}, J=7.2 \mathrm{~Hz}, 6 \mathrm{H})$;

${ }^{13} \mathrm{C}$ NMR (101 MHz, DMSO-d $\left.d_{6}\right) \delta 155.8,153.4,138.1$, 134.5, 128.9, 127.5, 127.2, 119.8, 115.4, 69.8, 34.4, 16.0;

LRMS $\left(\mathrm{ESI}^{+}\right) \mathrm{m} / z: 463(\mathrm{M}+\mathrm{H}, 30 \%) 147(100)$;

HRMS (ESI ${ }^{+}$): Calcd 463.2345 for $\mathrm{C}_{26} \mathrm{H}_{31} \mathrm{~N}_{4} \mathrm{O}_{4}[\mathrm{M}+\mathrm{H}]^{+}$; found, 463.2358.

1,1'-(((Furan-3,4-diylbis(methylene))bis(oxy))bis(4, 1phenylene))bis(3-ethylurea) (10i). Compound $10 \mathrm{i}$ was synthesized using general procedure 7 from 1-ethyl-3-(4hydroxyphenyl)urea (9) (1.209 g, $6.708 \mathrm{mmol})$, 3,4-bis(chloromethyl)furan $(\mathbf{5 i})(0.500 \mathrm{~g}, 3.049 \mathrm{mmol})$, potassium carbonate $(0.930 \mathrm{~g}, 6.708 \mathrm{mmol})$, and catalytic amount of potassium iodide in acetone $(50 \mathrm{~mL})$. The resulting residue was purified by flash chromatography (15\% EtOAc in hexane) to afford the title compound $(0.318 \mathrm{~g}, 34 \%)$ as a white solid (mp 201-202 $\left.{ }^{\circ} \mathrm{C}\right)$.

${ }^{1} \mathrm{H}$ NMR (400 MHz, DMSO- $\left.d_{6}\right) \delta 8.18(\mathrm{~s}, 2 \mathrm{H}), 7.74(\mathrm{~s}$, $2 \mathrm{H}), 7.25(\mathrm{~d}, J=9.0 \mathrm{~Hz}, 4 \mathrm{H}), 6.85(\mathrm{~d}, J=9.0 \mathrm{~Hz}, 4 \mathrm{H}), 5.98-$ $5.93(\mathrm{~m}, 2 \mathrm{H}), 4.93(\mathrm{~s}, 4 \mathrm{H}), 3.16-3.00(\mathrm{~m}, 4 \mathrm{H}), 1.03(\mathrm{t}, J=7.2$ $\mathrm{Hz}, 6 \mathrm{H})$;

${ }^{13} \mathrm{C}$ NMR (101 MHz, DMSO- $\left.d_{6}\right) \delta 155.8,153.2,142.8$, 134.5, 121.4, 119.7, 115.5, 61.2, 34.4, 16.0;

LRMS $\left(\mathrm{ESI}^{+}\right) \mathrm{m} / z: 453(\mathrm{M}+\mathrm{H}, 100 \%)$;

HRMS (ESI ${ }^{+}$): Calcd 453.2138 for $\mathrm{C}_{24} \mathrm{H}_{29} \mathrm{~N}_{4} \mathrm{O}_{5}[\mathrm{M}+\mathrm{H}]^{+}$; found, 453.2147 .

Di-tert-butyl((but-2-ene-1,4-diylbis(oxy))bis(2,1phenylene))(Z)-dicarbamate (7k). General Procedure 8: A suspension of (Z)-1,4-dichlorobutene (5e) (0.200 g, 1.622 $\mathrm{mmol}$ ), tert-butyl(2-hydroxyphenyl)carbamate (4b) (0.641 g, $3.318 \mathrm{mmol})$, and cesium carbonate $(1.081 \mathrm{~g}, 3.318 \mathrm{mmol})$ in anhydrous DMF $(15 \mathrm{~mL})$ was then heated at $75{ }^{\circ} \mathrm{C}$ for $3 \mathrm{~h}$. The resulting reaction mixture was then poured on ice water, and the solution was extracted with ethyl acetate $(2 \times 100 \mathrm{~mL})$. The organic layer was washed with water $(2 \times 100 \mathrm{~mL})$, saturated $\mathrm{NaHCO}_{3}(2 \times 100 \mathrm{~mL})$, and brine $(100 \mathrm{~mL})$. The organic layer was dried over $\mathrm{MgSO}_{4}$ and concentrated in vacuo. The resulting residue was purified by flash chromatography (2\% EtOAc in hexane) to afford the title compound $(0.227 \mathrm{~g}$, $34 \%)$ as a yellow gum.

${ }^{1} \mathrm{H}$ NMR (400 MHz, acetone- $\left.d_{6}\right) \delta 8.07(\mathrm{~d}, J=7.6 \mathrm{~Hz}, 2 \mathrm{H})$, 7.45 (s, 2H), $7.02(\mathrm{dd}, J=7.7,1.7 \mathrm{~Hz}, 2 \mathrm{H}), 6.98-6.89(\mathrm{~m}$, $4 \mathrm{H}), 6.00(\mathrm{t}, J=3.6 \mathrm{~Hz}, 2 \mathrm{H}), 4.85(\mathrm{~d}, J=4.1 \mathrm{~Hz}, 4 \mathrm{H}), 1.49(\mathrm{~s}$, $18 \mathrm{H})$;

${ }^{13} \mathrm{C}$ NMR $\left(101 \mathrm{MHz}, \mathrm{CDCl}_{3}\right) \delta 171.3,152.9,146.3,128.8$, 122.4, 121.8, 111.4, 80.6, 64.7, 28.5;

LRMS $\left(\mathrm{ESI}^{-}\right) \mathrm{m} / z: 515(\mathrm{M}+\mathrm{HCOOH}(-\mathrm{H}), 55 \%), 395$ (100);

HRMS (ESI ${ }^{+}$): Calcd 493.2309 for $\mathrm{C}_{26} \mathrm{H}_{34} \mathrm{~N}_{2} \mathrm{O}_{6} \mathrm{Na}[\mathrm{M}+$ $\mathrm{Na}]^{+}$; found, 493.2302.

Di-tert-butyl((but-2-ene-1,4-diylbis(oxy))bis(3,1phenylene))(Z)-dicarbamate (7j). Compound $7 \mathbf{j}$ was synthesized using general procedure 8 from tert-butyl(3- 
hydroxyphenyl)carbamate (4c) (0.641 g, $3.318 \mathrm{mmol}),(Z)-1,4-$ dichloro-2-butene $(5 e)(0.200 \mathrm{~g}, 1.622 \mathrm{mmol})$, cesium carbonate (1.081 g, $3.318 \mathrm{mmol})$, and anhydrous DMF (15 $\mathrm{mL}$ ). The resulting residue was purified by flash chromatography (2\% EtOAc in hexane) to afford the title compound $(0.339 \mathrm{~g}, 51 \%)$ as a white solid $\left(\mathrm{mp} 49-53{ }^{\circ} \mathrm{C}\right)$.

${ }^{1} \mathrm{H}$ NMR (400 MHz, acetone- $\left.d_{6}\right) \delta 8.35(\mathrm{~s}, 2 \mathrm{H}), 7.31(\mathrm{~s}$, $2 \mathrm{H}), 7.16(\mathrm{t}, J=8.1 \mathrm{~Hz}, 2 \mathrm{H}), 7.10(\mathrm{~d}, J=8.2 \mathrm{~Hz}, 2 \mathrm{H}), 6.62$ (dd, $J=8.1,1.5 \mathrm{~Hz}, 2 \mathrm{H}), 5.90-5.89(\mathrm{~m}, 2 \mathrm{H}), 4.76(\mathrm{~d}, J=4.1$ $\mathrm{Hz}, 4 \mathrm{H}), 1.47$ (s, 18H);

${ }^{13} \mathrm{C}$ NMR (101 MHz, acetone- $\left.d_{6}\right) \delta 160.0,153.6,141.9$, 130.3, 129.3, 111.6, 109.2, 105.8, 80.0, 64.9, 28.5;

LRMS $\left(\mathrm{ESI}^{-}\right) \mathrm{m} / z: 515(\mathrm{M}+\operatorname{HCOOH}(-\mathrm{H}), 55 \%), 395$ (100);

HRMS (ESI ${ }^{+}$): Calcd 493.2309 for $\mathrm{C}_{26} \mathrm{H}_{34} \mathrm{~N}_{2} \mathrm{O}_{6} \mathrm{Na}[\mathrm{M}+$ $\mathrm{Na}]^{+}$; found, 493.2311.

(Z)-3,3'-(But-2-ene-1,4-diylbis(oxy))dibenzenaminium Chloride (8k). Compound $\mathbf{8 k}$ was synthesized using general procedure 5 from di-tert-butyl((but-2-ene-1,4-diylbis(oxy))bis(2,1-phenylene $)(Z)$-dicarbamate $(7 \mathbf{k})(0.150 \mathrm{~g} 0.319 \mathrm{mmol})$ and $4 \mathrm{M} \mathrm{HCl}$ in dioxane $(5 \mathrm{~mL})$ to afford the title compound $(0.137 \mathrm{~g}, 98 \%)$ as an off-white solid $\left(\mathrm{mp} 241-243{ }^{\circ} \mathrm{C}\right)$.

${ }^{1} \mathrm{H}$ NMR (400 MHz, CD $\left.\mathrm{OD}\right) \delta 7.45(\mathrm{t}, J=8.3 \mathrm{~Hz}, 2 \mathrm{H})$, $7.07(\mathrm{~d}, J=8.9 \mathrm{~Hz}, 2 \mathrm{H}), 6.97-6.95(\mathrm{~m}, 4 \mathrm{H}), 5.95(\mathrm{t}, J=3.4$ $\mathrm{Hz}, 2 \mathrm{H}), 4.80$ (d, $J=3.7 \mathrm{~Hz}, 4 \mathrm{H})$;

${ }^{13} \mathrm{C}$ NMR (101 MHz, CD $\left.3 \mathrm{OD}\right) \delta 161.1,132.3,129.4,116.1$, 115.7, 110.9, 65.7;

LRMS $\left(\mathrm{ESI}^{+}\right) \mathrm{m} / z: 271(\mathrm{M}+\mathrm{H}, 100 \%)$.

HRMS (ESI ${ }^{+}$): Calcd 271.1446 for $\mathrm{C}_{16} \mathrm{H}_{19} \mathrm{~N}_{2} \mathrm{O}_{2}[\mathrm{M}+\mathrm{H}]^{+}$; found, 271.1440.

(Z)-2,2'-(But-2-ene-1,4-diylbis(oxy))dibenzenaminium Chloride (8j). Compound $\mathbf{8 j}$ was synthesized using general procedure 5 from di-tert-butyl((but-2-ene-1,4-diylbis(oxy))bis(3,1-phenylene $)(Z)$-dicarbamate $(7 \mathbf{j})(0.150 \mathrm{~g} 0.319 \mathrm{mmol})$ and $4 \mathrm{M} \mathrm{HCl}$ in dioxane $(5 \mathrm{~mL})$ to afford the title compound (0.0.98 g, 98\%) as an off-white solid (mp $157{ }^{\circ} \mathrm{C}($ dec.) $)$.

${ }^{1} \mathrm{H}$ NMR $\left(600 \mathrm{MHz}, \mathrm{CD}_{3} \mathrm{OD}\right) \delta 7.46(\mathrm{t}, J=7.9 \mathrm{~Hz}, 2 \mathrm{H})$, $7.41(\mathrm{~d}, J=7.8 \mathrm{~Hz}, 2 \mathrm{H}), 7.27(\mathrm{~d}, J=8.3 \mathrm{~Hz}, 2 \mathrm{H}), 7.10(\mathrm{t}, J=$ $7.7 \mathrm{~Hz}, 2 \mathrm{H}), 6.11-5.95(\mathrm{~m}, 2 \mathrm{H}), 4.96(\mathrm{~d}, J=3.1 \mathrm{~Hz}, 4 \mathrm{H})$;

${ }^{13} \mathrm{C}$ NMR (101 MHz, $\left.\mathrm{CD}_{3} \mathrm{OD}\right) \delta 148.2,129.8,123.6,122.8$, 122.2, 114.3, 64.0;

LRMS $\left(\mathrm{ESI}^{+}\right) \mathrm{m} / z: 271(\mathrm{M}+\mathrm{H}, 100 \%)$.

HRMS (ESI ${ }^{+}$): Calcd 271.1446 for $\mathrm{C}_{16} \mathrm{H}_{19} \mathrm{~N}_{2} \mathrm{O}_{2}[\mathrm{M}+\mathrm{H}]^{+}$; found, 271.1452.

(Z)-1,1'-((But-2-ene-1,4-diylbis(oxy))bis(3, 1-phenylene))bis(3-ethylurea) (10j). A solution of $\mathbf{8 j}(0.100 \mathrm{~g}, 0.291 \mathrm{mmol})$ and trimethylamine $(1.00 \mathrm{~mL}, 7.275 \mathrm{mmol})$ in anhydrous THF $(20 \mathrm{~mL})$ was heated to reflux, ethyl isocyanate $(0.090 \mathrm{~mL}$, $1.164 \mathrm{mmol}$ ) was added, and the mixture was refluxed overnight. The resulting reaction mixture was cooled to room temperature, adsorbed onto silica $(\sim 2.00 \mathrm{~g})$, and purified by flash chromatography (50\% EtOAc in hexane) to afford the title compound $(0.050 \mathrm{~g}, 42 \%)$ as a cream solid $\left(\mathrm{mp} 145-152{ }^{\circ} \mathrm{C}\right)$.

${ }^{1} \mathrm{H}$ NMR $\left(400 \mathrm{MHz}\right.$, acetone- $\left.d_{6}\right) \delta 7.94(\mathrm{~s}, 2 \mathrm{H}), 6.69(\mathrm{t}, J=$ $2.0 \mathrm{~Hz}, 2 \mathrm{H}), 6.64(\mathrm{t}, J=8.1 \mathrm{~Hz}, 2 \mathrm{H}), 6.42(\mathrm{~d}, J=8.1 \mathrm{~Hz}, 2 \mathrm{H})$, $6.05(\mathrm{dd}, J=8.1,2.2 \mathrm{~Hz}, 2 \mathrm{H}), 5.62(\mathrm{t}, J=5.4 \mathrm{~Hz}, 2 \mathrm{H}), 5.43-$ $5.34(\mathrm{~m}, 2 \mathrm{H}), 4.21(\mathrm{~d}, J=3.7 \mathrm{~Hz}, 4 \mathrm{H}), 2.72-2.56(\mathrm{~m}, 4 \mathrm{H})$, $0.59(\mathrm{t}, J=7.2 \mathrm{~Hz}, 6 \mathrm{H})$;

${ }^{13} \mathrm{C}$ NMR (101 MHz, DMSO- $\left.d_{6}\right) \delta 158.5,155.0,141.82$, 129.3, 128.4, 110.3, 107.0, 104.2, 63.7, 33.9, 15.4;

LRMS $\left(\mathrm{ESI}^{+}\right) \mathrm{m} / z: 413(\mathrm{M}+\mathrm{H}, 100 \%)$;

HRMS (ESI ${ }^{+}$): Calcd 413.2189 for $\mathrm{C}_{22} \mathrm{H}_{29} \mathrm{~N}_{4} \mathrm{O}_{4}[\mathrm{M}+\mathrm{H}]^{+}$; found, 429.2596 .
(Z)-1,1'-((But-2-ene-1,4-diylbis(oxy))bis(2,1-phenylene))bis(3-ethylurea) (10k). A solution of (Z)-3,3'-(but-2-ene-1,4diylbis(oxy))dibenzenaminium chloride $(8 \mathbf{k})$ (0.100 g, 0.291 mmol) and trimethylamine $(1.00 \mathrm{~mL}, 7.275 \mathrm{mmol})$ in anhydrous THF $(20 \mathrm{~mL})$ was heated to reflux, ethyl isocyanate $(0.090 \mathrm{~mL}, 1.164 \mathrm{mmol})$ was added, and the reflux was maintained overnight. The resulting reaction mixture was cooled to room temperature, adsorbed onto silica $(\sim 2.00 \mathrm{~g})$, and purified by flash chromatography (50\% EtOAc in hexane) to afford the title compound $(0.109 \mathrm{~g}, 91 \%)$ as an off-white solid (mp 196-201 $\left.{ }^{\circ} \mathrm{C}\right)$.

${ }^{1} \mathrm{H}$ NMR (600 MHz, acetone- $\left.d_{6}\right) \delta 8.25(\mathrm{dt}, J=7.9,1.4 \mathrm{~Hz}$, $2 \mathrm{H}), 7.58$ (brs, $2 \mathrm{H}), 6.94$ (dd, $J=7.6,1.7 \mathrm{~Hz}, 1 \mathrm{H}), 6.87-6.80$ $(\mathrm{m}, 4 \mathrm{H}), 6.33$ (brs, $2 \mathrm{H}), 5.93(\mathrm{t}, J=3.6 \mathrm{~Hz}, 2 \mathrm{H}), 4.77(\mathrm{~d}, J=$ $4.1 \mathrm{~Hz}, 4 \mathrm{H}), 3.22(\mathrm{q}, J=7.2 \mathrm{~Hz}, 2 \mathrm{H}), 1.10(\mathrm{t}, J=7.2 \mathrm{~Hz}, 3 \mathrm{H})$;

${ }^{13} \mathrm{C}$ NMR (151 MHz, acetone- $\left.d_{6}\right) \delta 155.9,147.3,131.3$, $129.4,121.9,121.8,119.4,112.7,65.6,35.0,15.8$;

LRMS $\left(\mathrm{ESI}^{+}\right) \mathrm{m} / z: 413(\mathrm{M}+\mathrm{H}, 100 \%)$;

HRMS (ESI ${ }^{+}$): Calcd 413.2189 for $\mathrm{C}_{22} \mathrm{H}_{29} \mathrm{~N}_{4} \mathrm{O}_{4}[\mathrm{M}+\mathrm{H}]^{+}$; found, 413.2184 .

(Z)-1-(4-((4-Chlorobut-2-en-1-yl)oxy)phenyl)-3-ethylurea (11). To a warmed $\left(75^{\circ} \mathrm{C}\right)$ solution of (Z)-1,4-dichloro-2butene (5e) (2.00 g, $16.137 \mathrm{mmol})$ in anhydrous DMF (10 $\mathrm{mL}$ ), a suspension of 1-ethyl-3-(4-hydroxyphenyl)urea (9) $(1.4454 \mathrm{~g}, 8.068 \mathrm{mmol}$ ) and cesium carbonate (5.252 g, 16.134 $\mathrm{mmol})$ in anhydrous DMF $(20 \mathrm{~mL})$ was added dropwise. The reaction mixture was then heated at $75^{\circ} \mathrm{C}$ for $2 \mathrm{~h}$, diluted with water $(200 \mathrm{~mL})$, and extracted with EtOAc $(2 \times 200 \mathrm{~mL})$. The organic layer was washed with water $(4 \times 200 \mathrm{~mL})$, dried over $\mathrm{MgSO}_{4}$, and concentrated in vacuo. The resulting residue was the recrystallized from $(10: 1)$ hexane/ethyl acetate to afford the title compound $(0.800 \mathrm{~g}, 37 \%)$ as a brown solid $\left(\mathrm{mp} 125{ }^{\circ} \mathrm{C}\right.$ (dec.)).

${ }^{1} \mathrm{H}$ NMR (400 MHz, acetone- $\left.d_{6}\right) \delta 7.63(\mathrm{~s}, 1 \mathrm{H}), 7.44-7.31$ $(\mathrm{m}, 2 \mathrm{H}), 6.87-6.78(\mathrm{~m}, 2 \mathrm{H}), 5.94-5.73(\mathrm{~m}, 2 \mathrm{H}), 4.69(\mathrm{~d}, J=$ $4.8 \mathrm{~Hz}, 2 \mathrm{H}), 4.32(\mathrm{~d}, J=6.9 \mathrm{~Hz}, 2 \mathrm{H}), 3.20(\mathrm{qd}, J=7.2,5.7 \mathrm{~Hz}$, $2 \mathrm{H}), 1.09(\mathrm{t}, J=7.2 \mathrm{~Hz}, 3 \mathrm{H})$;

${ }^{13} \mathrm{C}$ NMR (101 MHz, acetone- $\left.d_{6}\right) \delta 155.4,153.4,134.4$, $130.1,128.3,119.8,1148,63.6,39.2,34.3,15.1$;

LRMS $\left(\mathrm{ESI}^{+}\right) \mathrm{m} / z: 269\left(\mathrm{M}+\mathrm{H},{ }^{35} \mathrm{Cl}, 100 \%\right) 271(\mathrm{M}+\mathrm{H}$, $\left.{ }^{37} \mathrm{Cl}, 30 \%\right)$;

HRMS (ESI ${ }^{+}$): Calcd 269.1057 for $\mathrm{C}_{13} \mathrm{H}_{18} \mathrm{ClN}_{2} \mathrm{O}_{2}[\mathrm{M}+$ $\mathrm{H}]^{+}$; found, 269.1058 .

(Z)-2-(4-((4-(4-(3-Ethylureido)phenoxy)but-2-en-1-yl)oxy)phenyl)acetimidic Acid (13a). General Procedure 9: A solution of (Z)-1-(4-((4-chlorobut-2-en-1-yl)oxy)phenyl)-3-ethylurea (11) $(0.210 \mathrm{~g}, 0.714 \mathrm{mmol})$, 4-hydroxyphenylacetamide (12a) $(0.205 \mathrm{~g}, 1.356 \mathrm{mmol})$, and cesium carbonate $(0.450 \mathrm{~g}$, $1.381 \mathrm{mmol})$ in anhydrous DMF $(10 \mathrm{~mL})$ was heated at $75^{\circ} \mathrm{C}$ for $2 \mathrm{~h}$. On cooling, water $(100 \mathrm{~mL})$ was added and the solution was extracted with EtOAc $(2 \times 100 \mathrm{~mL})$. The combined organic layers were washed with water $(4 \times 100$ $\mathrm{mL}$ ), dried over $\mathrm{MgSO}_{4}$, and concentrated in vacuo. The resulting residue was then adsorbed onto silica $(\sim 1.00 \mathrm{~g})$ and purified by flash chromatography $\left(6.5 \% \mathrm{CH}_{3} \mathrm{OH}\right.$ in $\left.\mathrm{CH}_{2} \mathrm{Cl}_{2}\right)$ to afford the title compound $(0.110 \mathrm{~g}, 40 \%)$ as a white solid (mp $\left.180-181{ }^{\circ} \mathrm{C}\right)$.

${ }^{1} \mathrm{H}$ NMR (400 MHz, DMSO-d $\left.d_{6}\right) \delta 8.18(\mathrm{~s}, 1 \mathrm{H}), 7.37$ (bs, $1 \mathrm{H}), 7.26(\mathrm{~d}, J=9.0 \mathrm{~Hz}, 2 \mathrm{H}), 7.16(\mathrm{~d}, J=8.6 \mathrm{~Hz}, 2 \mathrm{H}), 6.89(\mathrm{~d}$, $J=8.6,2 \mathrm{H}), 6.84(\mathrm{~d}, J=9.0 \mathrm{~Hz}, 2 \mathrm{H}), 6.81(\mathrm{bs}, 1 \mathrm{H}), 5.99-5.91$ (m, 1H), 5.86-5.76 (m, 2H), $4.66(\mathrm{dd}, J=14.1,3.5 \mathrm{~Hz}, 4 \mathrm{H})$, 3.14-3.01 (m, 2H), $1.03(\mathrm{t}, J=7.2 \mathrm{~Hz}, 3 \mathrm{H})$; 
${ }^{13} \mathrm{C}$ NMR (101 MHz, DMSO- $\left.d_{6}\right)$ 173.0, 157.2, 155.8, 153.1, $134.5,130.5,129.2,129.1,128.8,119.8,115.3,114.9,64.5,64.3$, 41.8, 34.4, 16.0;

LRMS $\left(\mathrm{ESI}^{+}\right) \mathrm{m} / z: 384(\mathrm{M}+\mathrm{H}, 100 \%)$;

HRMS $\left(\mathrm{ESI}^{+}\right)$: Calcd 384.1923 for $\mathrm{C}_{21} \mathrm{H}_{26} \mathrm{~N}_{3} \mathrm{O}_{4}[\mathrm{M}+\mathrm{H}]^{+}$; found, 384.1934 .

(Z)-3-(4-((4-(4-(3-Ethylureido)phenoxy)but-2-en-1-yl)oxy)phenyl)propanoic Acid (13b). Compound $13 \mathrm{~b}$ was synthesized using general procedure 9 from 3-(4-hydroxyphenyl)propionic acid (12b) (0.225 g, $1.356 \mathrm{mmol}),(Z)-1-(4-((4-$ chlorobut-2-en-1-yl)oxy)phenyl)-3-ethylurea (11) (0.210 g, $0.714 \mathrm{mmol})$, and cesium carbonate $(0.450 \mathrm{~g}, 1.381 \mathrm{mmol})$ in anhydrous DMF $(10 \mathrm{~mL})$. The resulting reaction mixture was purified by flash chromatography $\left(7.5 \% \mathrm{CH}_{3} \mathrm{OH}\right.$ in $\left.\mathrm{CH}_{2} \mathrm{Cl}_{2}\right)$ to afford the title compound $(0.137 \mathrm{~g}, 28 \%)$ as an white solid ( $\left.\mathrm{mp} 95-97{ }^{\circ} \mathrm{C}\right)$.

${ }^{1} \mathrm{H}$ NMR (400 MHz, DMSO-d $\left.d_{6}\right) \delta 9.16(\mathrm{~s}, 1 \mathrm{H}), 8.19$ (s, $1 \mathrm{H}), 7.27(\mathrm{~d}, J=9.1 \mathrm{~Hz}, 2 \mathrm{H}), 7.00(\mathrm{~d}, J=8.5 \mathrm{~Hz}, 2 \mathrm{H}), 6.82(\mathrm{~d}$, $J=9.0 \mathrm{~Hz}, 2 \mathrm{H}), 6.65(\mathrm{~d}, J=8.5,2 \mathrm{H}), 5.96(\mathrm{t}, J=5.2 \mathrm{~Hz}, 1 \mathrm{H})$, $5.81\left(\mathrm{dtt},{ }^{3} \mathrm{~J}_{\mathrm{CH}}=10.9,{ }^{3} \mathrm{~J}_{\mathrm{CH}_{2}}=6.1,{ }^{4} J_{\mathrm{CH}_{2}}=1.4 \mathrm{~Hz} 1 \mathrm{H}\right), 5.65(\mathrm{dtt}$, $\left.{ }^{3} J_{\mathrm{CH}}=11.3,{ }^{3} J_{\mathrm{CH}_{2}}=6.6,{ }^{4} J_{\mathrm{CH}_{2}}=1.4 \mathrm{~Hz}, 1 \mathrm{H}\right), 4.62(\mathrm{dd}, J=27.5$, $6.5 \mathrm{~Hz}, 4 \mathrm{H}), 3.08(\mathrm{dq}, J=7.1,6.5 \mathrm{~Hz}, 2 \mathrm{H}), 2.73(\mathrm{t}, J=7.6 \mathrm{~Hz}$, $2 \mathrm{H}), 2.56(\mathrm{t}, J=7.5 \mathrm{~Hz}, 2 \mathrm{H}), 1.03(\mathrm{t}, J=7.2 \mathrm{~Hz}, 3 \mathrm{H})$;

${ }^{13} \mathrm{C}$ NMR (101 MHz, DMSO- $\left.d_{6}\right) \delta 172.6,156.1,155.8$, $153.1,134.5,130.9,130.1,129.6,127.4,119.8,115.5,115.2$, 64.3, 60.3, 35.9, 34.4, 29.9, 16.0;

LRMS $\left(\mathrm{ESI}^{+}\right) \mathrm{m} / z: 399(\mathrm{M}+\mathrm{H}, 100 \%)$;

HRMS $\left(\right.$ ESI $^{+}$): Calcd 399.1920 for $\mathrm{C}_{22} \mathrm{H}_{27} \mathrm{~N}_{2} \mathrm{O}_{5}[\mathrm{M}+\mathrm{H}]^{+}$; found, 399.1931.

(Z)-3-(4-((4-(4-(3-Ethylureido)phenoxy)but-2-en-1-yl)oxy)phenyl)acetic Acid (13c). Compound 13c was synthesized using general procedure 9 from 4-hydroxyphenylacetic acid (12c) $(0.210 \mathrm{~g}, 1.356 \mathrm{mmol}),(Z)-1-(4-((4-c h l o r o b u t-2-e n-1-$ yl)oxy)phenyl)-3-ethylurea (11) (0.210 g, $0.714 \mathrm{mmol})$, and cesium carbonate $(0.450 \mathrm{~g}, 1.381 \mathrm{mmol})$ in anhydrous DMF $(10 \mathrm{~mL})$. The resulting reaction mixture was purified by flash chromatography $\left(3 \% \mathrm{CH}_{3} \mathrm{OH}\right.$ in $\mathrm{CH}_{2} \mathrm{Cl}_{2}$ ) to afford the title compound $(0.100 \mathrm{~g}, 27 \%)$ as a tan solid (mp 92-93 $\left.{ }^{\circ} \mathrm{C}\right)$.

${ }^{1} \mathrm{H}$ NMR (400 MHz, DMSO-d $\left.{ }_{6}\right) \delta 9.30(\mathrm{~s}, 1 \mathrm{H}), 8.18(\mathrm{~s}$, $1 \mathrm{H}), 7.26(\mathrm{~d}, J=9.0 \mathrm{~Hz}, 2 \mathrm{H}), 7.05(\mathrm{~d}, J=8.5 \mathrm{~Hz}, 2 \mathrm{H}), 6.80$ (d, $J=9.0 \mathrm{~Hz}, 2 \mathrm{H}), 6.69(\mathrm{~d}, J=8.5 \mathrm{~Hz}, 2 \mathrm{H}), 5.96(\mathrm{t}, J=5.5 \mathrm{~Hz}$, $1 \mathrm{H}), 5.81\left(\mathrm{dtt},{ }^{3} J_{\mathrm{CH}}=10.9,{ }^{3} J_{\mathrm{CH}_{2}}=6.1,{ }^{4} J_{\mathrm{CH}_{2}}=1.4 \mathrm{~Hz} 1 \mathrm{H}\right), 5.65$ $\left(\mathrm{dtt},{ }^{3} J_{\mathrm{CH}}=11.3,{ }^{3} \mathrm{~J}_{\mathrm{CH}_{2}}=6.6,{ }^{4} \mathrm{~J}_{\mathrm{CH}_{2}}=1.4 \mathrm{~Hz}, 1 \mathrm{H}\right), 4.63(\mathrm{dd}, J=$ 27.5, $6.5 \mathrm{~Hz}, 4 \mathrm{H}), 3.54(\mathrm{~s}, 2 \mathrm{H}), 3.15-2.96(\mathrm{~m}, 2 \mathrm{H}), 1.03(\mathrm{t}, J=$ $7.2 \mathrm{~Hz}, 3 \mathrm{H})$;

${ }^{13} \mathrm{C}$ NMR (101 MHz, DMSO- $\left.d_{6}\right) \delta 171.4,156.3,155.4$, $152.6,134.0,130.3,129.8,126.8,124.3,119.3,115.1,114.8$, 63.8, 60.2, 39.4, 34.0, 15.5;

LRMS $\left(\mathrm{ESI}^{+}\right) \mathrm{m} / z: 385(\mathrm{M}+\mathrm{H}, 100 \%)$

HRMS $\left(\right.$ ESI $^{+}$): Calcd 385.1763 for $\mathrm{C}_{21} \mathrm{H}_{25} \mathrm{~N}_{2} \mathrm{O}_{5}[\mathrm{M}+\mathrm{H}]^{+}$; found, 385.1772 .

$(R, Z)-2-(($ tert-Butoxycarbonyl)amino)-3-(4-((4-(4-(3ethylureido)phenoxy)but-2-en-1-yl)oxy)phenyl)propanoic Acid (13d). General Procedure 10: To a microwave vial, (tertbutoxycarbonyl)-L-tyrosine (12d) $(0.381 \mathrm{~g}, 1.356 \mathrm{mmol}),(Z)$ 1-(4-((4-chlorobut-2-en-1-yl)oxy)phenyl)-3-ethylurea (11) $(0.210 \mathrm{~g}, 0.714 \mathrm{mmol})$, and cesium carbonate $(0.450 \mathrm{~g}, 1.381$ $\mathrm{mmol})$ were added in anhydrous DMF $(2.5 \mathrm{~mL})$. The suspension was subjected to microwave irradiation at $85{ }^{\circ} \mathrm{C}$ for $30 \mathrm{~min}$. The resulting reaction mixture was poured into water $(50 \mathrm{~mL})$ and extracted with EtOAc $(2 \times 50 \mathrm{~mL})$. The combined organic layers were washed with $1 \mathrm{M} \mathrm{NaOH}(100$
$\mathrm{mL})$, water $(4 \times 100 \mathrm{~mL})$, and saturated brine $(100 \mathrm{~mL})$; dried over $\mathrm{MgSO}_{4}$ adsorbed onto silica $(\sim 1.00 \mathrm{~g})$; and purified by flash chromatography (50:50 EtOAc/hexane) to afford the title compound $(0.300 \mathrm{~g}, 81 \%)$ as a white solid $\left(\mathrm{mp}<50{ }^{\circ} \mathrm{C}\right)$.

${ }^{1} \mathrm{H}$ NMR (400 MHz, acetone- $\left.d_{6}\right) \delta 8.23(\mathrm{~s}, 1 \mathrm{H}), 7.65(\mathrm{~s}$, $1 \mathrm{H}), 7.44-7.27(\mathrm{~m}, 2 \mathrm{H}), 7.06(\mathrm{~d}, J=8.2 \mathrm{~Hz}, 2 \mathrm{H}), 6.92-6.80$ $(\mathrm{m}, 2 \mathrm{H}), 6.75(\mathrm{~d}, J=8.4 \mathrm{~Hz}, 2 \mathrm{H}), 6.04(\mathrm{~d}, J=7.7 \mathrm{~Hz}, 1 \mathrm{H})$, $5.87(\mathrm{dt}, J=11.6,5.9 \mathrm{~Hz}, 1 \mathrm{H}), 5.79-5.54(\mathrm{~m}, 2 \mathrm{H}), 4.75(\mathrm{t}, J=$ $5.8 \mathrm{~Hz}, 2 \mathrm{H}), 4.68(\mathrm{~d}, J=5.6 \mathrm{~Hz}, 2 \mathrm{H}), 4.37-4.32(\mathrm{~m}, 1 \mathrm{H})$, 3.24-3.17 (m, 2H), 2.89-3.04 (ddd, $J=21.9,13.8,6.7 \mathrm{~Hz}$, $2 \mathrm{H}), 1.36(\mathrm{~s}, 9 \mathrm{H}), 1.09(\mathrm{t}, J=7.2 \mathrm{~Hz}, 3 \mathrm{H})$;

${ }^{13} \mathrm{C}$ NMR (101 MHz, acetone- $\left.d_{6}\right) \delta 172.7,157.2,156.4$, 156.2 , 154.44, 135.1, 131.2, 131.1, 128.6, 127.3, 120.9, 120.8, 116.1, 115.7, 79.36, 6.76, 63.8, 56.4, 37.5, 35.3, 29.8, 28.5, 15.6; LRMS $\left(\mathrm{ESI}^{-}\right) \mathrm{m} / z: 512(\mathrm{M}-\mathrm{H}, 100 \%)$;

HRMS $\left(\mathrm{ESI}^{+}\right.$): Calcd 514.2553 for $\mathrm{C}_{27} \mathrm{H}_{36} \mathrm{~N}_{3} \mathrm{O}_{7}[\mathrm{M}+\mathrm{H}]^{+}$; found, 514.2557.

(S,Z)-2-((tert-Butoxycarbonyl)amino)-3-(4-((4-(4-(3ethylureido)phenoxy)but-2-en-1-yl)oxy)phenyl)propanoic Acid (13e). Compound 13e was synthesized using general procedure 10 from (tert-butoxycarbonyl)-L-tyrosine (12e) (0.200 g, $0.712 \mathrm{mmol}),(Z)-1-(4-((4-c h l o r o b u t-2-e n-1-y l)$ oxy $)$ phenyl)-3-ethylurea (11) (0.109 g, $0.370 \mathrm{mmol})$, and cesium carbonate $(0.232 \mathrm{~g}, 0.712 \mathrm{mmol})$ in anhydrous DMF $(3 \mathrm{~mL})$ to afford the title compound $(0.151 \mathrm{~g}, 79 \%)$ as a white solid (mp $<50{ }^{\circ} \mathrm{C}$ ).

${ }^{1} \mathrm{H}$ NMR (400 MHz, acetone- $\left.d_{6}\right) \delta 8.23(\mathrm{~s}, 1 \mathrm{H}), 7.65(\mathrm{~s}$, $1 \mathrm{H}), 7.44-7.27(\mathrm{~m}, 2 \mathrm{H}), 7.06(\mathrm{~d}, J=8.2 \mathrm{~Hz}, 2 \mathrm{H}), 6.92-6.80$ $(\mathrm{m}, 2 \mathrm{H}), 6.75(\mathrm{~d}, J=8.4 \mathrm{~Hz}, 2 \mathrm{H}), 6.04(\mathrm{~d}, J=7.7 \mathrm{~Hz}, 1 \mathrm{H})$, $5.87(\mathrm{dt}, J=11.6,5.9 \mathrm{~Hz}, 1 \mathrm{H}), 5.79-5.54(\mathrm{~m}, 2 \mathrm{H}), 4.75(\mathrm{t}, J=$ $5.8 \mathrm{~Hz}, 2 \mathrm{H}), 4.68(\mathrm{~d}, J=5.6 \mathrm{~Hz}, 2 \mathrm{H}), 4.37-4.32(\mathrm{~m}, 1 \mathrm{H})$, $3.24-3.17(\mathrm{~m}, 2 \mathrm{H}), 2.89-3.04(\mathrm{ddd}, J=21.9,13.8,6.7 \mathrm{~Hz}$, $2 \mathrm{H}), 1.36(\mathrm{~s}, 9 \mathrm{H}), 1.09(\mathrm{t}, J=7.2 \mathrm{~Hz}, 3 \mathrm{H})$.

${ }^{13} \mathrm{C}$ NMR (101 MHz, acetone- $\left.d_{6}\right) \delta 172.7,157.2,156.4$, 156.2 , 154.44, 135.1, 131.2, 131.1, 128.6, 127.3, 120.9, 120.8, 116.1, 115.7, 79.36, 6.76, 63.8, 56.4, 37.5, 35.3, 29.8, 28.5, 15.6; LRMS $\left(\mathrm{ESI}^{-}\right) \mathrm{m} / z: 512(\mathrm{M}-\mathrm{H}, 100 \%)$;

HRMS (ESI ${ }^{+}$): Calcd 514.2553 for $\mathrm{C}_{27} \mathrm{H}_{36} \mathrm{~N}_{3} \mathrm{O}_{7}[\mathrm{M}+\mathrm{H}]^{+}$; found, 514.2556 .

(R,Z)-1-Carboxy-2-(4-((4-(4-(3-ethylureido)phenoxy)but-2en-1-yl)oxy)phenyl)ethan-1-aminium Chloride (13g). Compound $13 \mathrm{~g}$ was synthesized using general procedure 5 from $(R, Z)-2-(($ tert-butoxycarbonyl) amino )-3-(4-((4-(4-(3ethylureido)phenoxy)but-2-en-1-yl)oxy)phenyl)propanoic acid (13d) $(0.150 \mathrm{~g}, 0.292 \mathrm{mmol})$ and $4 \mathrm{M} \mathrm{HCl}$ in 1,4-dioxane (5 $\mathrm{mL})$ to afford the title compound $(0.117 \mathrm{~g}, 89 \%)$ as a brown gum.

${ }^{1} \mathrm{H}$ NMR (400 MHz, DMSO) $\delta 9.39$ (bs, $1 \mathrm{H}$ ), 8.37 (bs, $2 \mathrm{H}$ ), $8.28-8.20(\mathrm{~m}, 1 \mathrm{H}), 7.28(\mathrm{~d}, J=9.0 \mathrm{~Hz}, 2 \mathrm{H}), 7.01(\mathrm{~d}, J=8.4$ $\mathrm{Hz}, 2 \mathrm{H}), 6.82(\mathrm{~d}, J=9.0 \mathrm{~Hz}, 2 \mathrm{H}), 6.71(\mathrm{~d}, J=8.4 \mathrm{~Hz}, 2 \mathrm{H})$, $6.03(\mathrm{bs}, 1 \mathrm{H}), 5.95-5.80(\mathrm{~m}, 1 \mathrm{H}), 5.63-5.53(\mathrm{~m}, 1 \mathrm{H}), 4.78(\mathrm{~d}$, $J=6.7 \mathrm{~Hz}, 2 \mathrm{H}), 4.60(\mathrm{~d}, J=5.9 \mathrm{~Hz}, 2 \mathrm{H}), 4.27-4.22(\mathrm{~m}, 1 \mathrm{H})$, $3.13-2.88(\mathrm{~m}, 4 \mathrm{H}), 1.03(\mathrm{t}, J=7.2 \mathrm{~Hz}, 3 \mathrm{H})$;

${ }^{13} \mathrm{C}$ NMR $\left(101 \mathrm{MHz}, \mathrm{CD}_{3} \mathrm{OD}\right) \delta 170.0,158.8,158.4,155.6$, $134.3,132.2$, 131.6, 126.7, 125.5, 122.7, 116.9, 116.1, 65.4, 63.0, 55.4, 36.7, 35.7, 15.7;

LRMS (ESI $\left.{ }^{-}\right) m / z: 412(\mathrm{M}-\mathrm{H}, 100 \%), 448(\mathrm{M}+\mathrm{Cl}-\mathrm{H}$, $85 \%)$;

HRMS (ESI ${ }^{+}$): Calcd 414.2029 for $\mathrm{C}_{22} \mathrm{H}_{28} \mathrm{~N}_{3} \mathrm{O}_{5}[\mathrm{M}+\mathrm{H}]^{+}$; found, 413.3191 .

(S,Z)-1-Carboxy-2-(4-((4-(4-(3-ethylureido)phenoxy)but-2en-1-yl)oxy)phenyl)ethan-1-aminium Chloride (13h). Compound $13 \mathrm{~h}$ was synthesized using general procedure 5 from 
$(S, Z)$-2-( (tert-butoxycarbonyl) amino )-3-(4-( (4-(4-(3ethylureido)phenoxy)but-2-en-1-yl)oxy)phenyl)propanoic acid (13e) $(0.127 \mathrm{~g}, 0.247 \mathrm{mmol})$ and $4 \mathrm{M} \mathrm{HCl}$ in 1,4-dioxane (5 $\mathrm{mL})$ to afford the title compound $(0.104 \mathrm{~g}, 94 \%)$ as a brown gum.

${ }^{1} \mathrm{H}$ NMR (400 MHz, CD $\left.30 D\right) \delta 7.22(\mathrm{~d}, J=9.0 \mathrm{~Hz}, 2 \mathrm{H})$, $6.99(\mathrm{~d}, J=8.5 \mathrm{~Hz}, 2 \mathrm{H}), 6.85(\mathrm{~d}, J=9.0 \mathrm{~Hz}, 2 \mathrm{H}), 6.70(\mathrm{~d}, J=$ $8.5 \mathrm{~Hz}, 2 \mathrm{H}), 5.86\left(\mathrm{dtt},{ }^{3} J_{\mathrm{CH}}=11.2,{ }^{3} J_{\mathrm{CH}_{2}}=6.0,{ }^{4} J_{\mathrm{CH}_{2}}=1.3 \mathrm{~Hz}\right.$, $1 \mathrm{H}), 5.66\left(\mathrm{dtt},{ }^{3} \mathrm{~J}_{\mathrm{CH}}=11.2,{ }^{3} \mathrm{~J}_{\mathrm{CH}_{2}}=6.8,{ }^{4} \mathrm{~J}_{\mathrm{CH}_{2}}=1.6 \mathrm{~Hz}, 1 \mathrm{H}\right)$, $4.72(\mathrm{~d}, J=6.8 \mathrm{~Hz}, 2 \mathrm{H}), 4.62(\mathrm{~d}, J=5.8 \mathrm{~Hz}, 2 \mathrm{H}), 3.65(\mathrm{t}, J=$ $6.5 \mathrm{~Hz}, 1 \mathrm{H}), 3.21$ (q, $J=7.2 \mathrm{~Hz}, 2 \mathrm{H}), 2.94-2.75(\mathrm{~m}, 2 \mathrm{H}), 1.14$ (t, $J=7.2 \mathrm{~Hz}, 3 \mathrm{H})$;

${ }^{13} \mathrm{C}$ NMR (101 MHz, CD $\left.\mathrm{CD}_{3} \mathrm{OD}\right) \delta 170.0,158.8,158.4,155.6$, 134.3, 132.2, 131.6, 126.7, 125.5, 122.7, 116.9, 116.1, 65.4, 63.0, 55.4, 36.7, 35.7, 15.7;

LRMS $\left(\mathrm{ESI}^{+}\right) m / z: 414(\mathrm{M}+\mathrm{H}, 100 \%)$.

HRMS $\left(\mathrm{ESI}^{+}\right)$: Calcd 413.1951 for $\mathrm{C}_{22} \mathrm{H}_{27} \mathrm{~N}_{3} \mathrm{O}_{5}[\mathrm{M}]^{+}$; found, 413.2191.

(Z)-2-(4-((4-(4-(3-Ethylureido)phenoxy)but-2-en-1-yl)oxy)phenyl)ethan-1-aminium (13i). Compound 13i was synthesized using general procedure 10 from tert-butyl (4hydroxyphenethyl)carbamate (12i) (0.322 g, $1.356 \mathrm{mmol})$, (Z)-1-(4-((4-chlorobut-2-en-1-yl)oxy)phenyl)-3-ethylurea (11) $(0.210 \mathrm{~g}, 0.714 \mathrm{mmol})$, and cesium carbonate $(0.450 \mathrm{~g}, 1.381$ $\mathrm{mmol}$ ) in DMF $(3 \mathrm{~mL})$. The resulting reaction mixture was washed with water $(3 \times 50 \mathrm{~mL})$ and brine $(50 \mathrm{~mL})$. The organic layer was dried over $\mathrm{MgSO}_{4}$ and concentrated in vacuo. The resulting residue was taken up in $4 \mathrm{M} \mathrm{HCl}$ in dioxane (5 $\mathrm{mL})$, stirred at room temperature for $2 \mathrm{~h}$, diluted with ether $(25$ $\mathrm{mL}$ ), and cooled to $0{ }^{\circ} \mathrm{C}$. The precipitate was then filtered to afford the title compound $(0.085 \mathrm{~g}, 29 \%)$ as a white solid (mp $\left.177-179{ }^{\circ} \mathrm{C}\right)$.

${ }^{1} \mathrm{H}$ NMR (400 MHz, DMSO- $\left.d_{6}\right) \delta 8.40(\mathrm{~s}, 1 \mathrm{H}), 7.93$ (bs, $3 \mathrm{H}), 7.28(\mathrm{~d}, J=9.0 \mathrm{~Hz}, 2 \mathrm{H}), 7.17(\mathrm{~d}, J=8.6 \mathrm{~Hz}, 2 \mathrm{H}), 6.92(\mathrm{~d}$, $J=8.6 \mathrm{~Hz}, 2 \mathrm{H}), 6.83(\mathrm{~d}, J=9.1 \mathrm{~Hz}, 2 \mathrm{H}), 6.11(\mathrm{bs}, 1 \mathrm{H}), 5.89-$ $5.76(\mathrm{~m}, 2 \mathrm{H}), 4.66(\mathrm{dd}, J=19.5,4.4 \mathrm{~Hz}, 4 \mathrm{H}), 3.07(\mathrm{q}, J=7.2$ $\mathrm{Hz}, 2 \mathrm{H}), 3.03-2.91(\mathrm{~m}, 2 \mathrm{H}), 2.84-2.75(\mathrm{~m}, 2 \mathrm{H}), 1.03(\mathrm{t}, J=$ $7.2 \mathrm{~Hz}, 3 \mathrm{H})$;

${ }^{13} \mathrm{C}$ NMR (101 MHz, DMSO- $\left.d_{6}\right) \delta 157.4,155.9,153.0$, $134.6,130.2,129.8,129.2,128.7,119.6,115.3,115.3,64.5,64.3$, 40.6, 34.4, 32.6, 16.0;

LRMS $\left(\mathrm{ESI}^{+}\right) \mathrm{m} / z: 370(\mathrm{M}-\mathrm{Cl}, 100 \%)$;

HRMS (ESI ${ }^{+}$): Calcd 370.2130 for $\mathrm{C}_{21} \mathrm{H}_{28} \mathrm{~N}_{3} \mathrm{O}_{3}[\mathrm{M}+\mathrm{H}]^{+}$; found, 370.2133 .

(Z)-1,1'-((But-2-ene-1,4-diylbis(oxy))bis(4,1-phenylene))bis(ethan-1-one) (15a). Compound 15a was synthesized using general procedure 1 from 4-hydroxyacetophenone (14a) (0.130 g, $0.948 \mathrm{mmol}),(Z)$-1,4-dichloro-2-butene $(5 \mathbf{e})(0.040 \mathrm{~mL}$, $0.380 \mathrm{mmol})$, potassium carbonate $(0.131 \mathrm{~g}, 0.948 \mathrm{mmol})$, and potassium iodide $(0.147 \mathrm{~g}, 0.890 \mathrm{mmol})$ in acetonitrile (50 $\mathrm{mL})$ to afford the title compound $(0.089 \mathrm{~g}, 73 \%)$ as an offwhite solid (mp $74{ }^{\circ} \mathrm{C}$ (dec.)).

${ }^{1} \mathrm{H}$ NMR (400 MHz, $\left.\mathrm{CDCl}_{3}\right) \delta 7.93(\mathrm{~d}, J=8.9 \mathrm{~Hz}, 4 \mathrm{H}), 6.94$ $(\mathrm{d}, J=8.9 \mathrm{~Hz}, 4 \mathrm{H}), 501-5.94(\mathrm{~m}, 2 \mathrm{H}), 4.76(\mathrm{~d}, J=4.1 \mathrm{~Hz}$, $4 \mathrm{H}), 2.55$ (s, 6H);

${ }^{13} \mathrm{C}$ NMR $\left(101 \mathrm{MHz}, \mathrm{CDCl}_{3}\right) \delta 196.7,162.2,130.7,130.7$, 128.3, 114.3, 64.3, 26.4;

LRMS $\left(\mathrm{ESI}^{+}\right) m / z: 365(\mathrm{M}+\mathrm{H}, 100 \%), 247(\mathrm{M}+\mathrm{Na}$ $25 \%)$;

HRMS (ESI ${ }^{+}$): Calcd 325.144 for $\mathrm{C}_{20} \mathrm{H}_{21} \mathrm{O}_{4}[\mathrm{M}+\mathrm{H}]^{+}$; found, 325.1449 .
(Z)-1,4-Bis(4-chlorophenoxy)but-2-ene (15b). Compound 15b was synthesized using general procedure 1 from 4chlorophenol (14b) (0.102 g, $0.800 \mathrm{mmol})$, (Z)-1,4-dichloro-2butene $(5 \mathbf{e})(0.040 \mathrm{~mL}, 0.380 \mathrm{mmol})$, potassium carbonate $(0.111 \mathrm{~g}, 0.800 \mathrm{mmol})$, and potassium iodide $(0.147 \mathrm{~g}, 0.890$ $\mathrm{mmol})$ in acetonitrile $(50 \mathrm{~mL})$ to afford the title compound $(0.115 \mathrm{~g}, 98 \%)$ as a cream solid $\left(\mathrm{mp} 37-41{ }^{\circ} \mathrm{C}\right) .{ }^{44}$

${ }^{1} \mathrm{H}$ NMR (400 MHz, DMSO- $\left.d_{6}\right) \delta 7.42-7.23(\mathrm{~m}, 4 \mathrm{H})$, $7.08-6.86(\mathrm{~m}, 4 \mathrm{H}), 5.96-5.78(\mathrm{~m}, 2 \mathrm{H}), 4.72(\mathrm{~d}, J=4.2 \mathrm{~Hz}$, $2 \mathrm{H})$;

${ }^{13} \mathrm{C}$ NMR (101 MHz, DMSO- $\left.d_{6}\right) \delta 161.6,134.2,128.3$, 119.10, 115.8, 103.0, 64.3;

LRMS $\left(\mathrm{ESI}^{-}\right) \mathrm{m} / z: 307\left(\mathrm{M}-\mathrm{H},{ }^{35} \mathrm{Cl}_{2}, 100 \%\right), 309(\mathrm{M}-\mathrm{H}$, $\left.{ }^{37} \mathrm{Cl}_{2}, 75 \%\right), 311\left(\mathrm{M}-\mathrm{H},{ }^{35} \mathrm{Cl}^{37} \mathrm{Cl}, 25 \%\right)$.

(Z)-1,4-Bis(4-methoxyphenoxy)but-2-ene (15c). Compound $15 \mathrm{c}$ was synthesized using general procedure 1 from 4-hydroxyanisole (14c) (1.099 g, $8.870 \mathrm{mmol}),(Z)-1,4-$ dichloro-2-butene $(5 \mathbf{5})(0.421 \mathrm{~mL}, 4.030 \mathrm{mmol})$, potassium carbonate $(1.226 \mathrm{~g}, 8.89 \mathrm{mmol})$, and potassium iodide $(0.147 \mathrm{~g}$, $0.890 \mathrm{mmol})$ in acetonitrile $(50 \mathrm{~mL})$ to afford the title compound $(0.723 \mathrm{~g}, 60 \%)$ as an off-white solid (mp 112-122 $\left.{ }^{\circ} \mathrm{C}\right) .{ }^{45}$

${ }^{1} \mathrm{H}$ NMR (400 MHz, CD $\left.\mathrm{OD}\right) \delta 6.93-6.81(\mathrm{~m}, 8 \mathrm{H}), 5.94-$ $5.83(\mathrm{~m}, 2 \mathrm{H}), 4.65(\mathrm{~d}, J=4.1 \mathrm{~Hz}, 4 \mathrm{H}), 3.76(\mathrm{~s}, 6 \mathrm{H})$;

${ }^{13} \mathrm{C}$ NMR (101 MHz, CD $\left.{ }_{3} \mathrm{OD}\right) \delta 154.2,152.6,128.4,115.5$, 114.3, 64.6, 54.7;

LRMS (EI, $70 \mathrm{eV}) \mathrm{m} / z: 300\left(\mathrm{M}^{+\bullet}, 10 \%\right), 177$ (35), 123 (100);

HRMS $\left(\right.$ ESI $^{+}$): Calcd 301.1440 for $\mathrm{C}_{18} \mathrm{H}_{21} \mathrm{O}_{4}[\mathrm{M}+\mathrm{H}]^{+}$; found, 301.1384.

(Z)-4,4'-(But-2-ene-1,4-diylbis(oxy))dibenzonitrile (15d). Compound 15d was synthesized using general procedure 1 from 4-hydroxybenzonitrile (15b) $(0.095 \mathrm{~g}, 0.800 \mathrm{mmol}),(Z)$ 1,4-dichloro-2-butene $(5 \mathbf{5})(0.040 \mathrm{~mL}, 0.380 \mathrm{mmol})$, potassium carbonate $(0.111 \mathrm{~g}, 0.800 \mathrm{mmol})$, and potassium iodide $(0.147$ g, $0.890 \mathrm{mmol})$ in acetonitrile $(50 \mathrm{~mL})$ to afford the title compound $(0.063 \mathrm{~g}, 57 \%)$ as an off-white solid (mp 122-124 $\left.{ }^{\circ} \mathrm{C}\right)$.

${ }^{1} \mathrm{H}$ NMR (400 MHz, DMSO- $\left.d_{6}\right) \delta 7.78(\mathrm{~d}, J=8.7 \mathrm{~Hz}, 4 \mathrm{H})$, $7.14(\mathrm{~d}, J=8.8 \mathrm{~Hz}, 4 \mathrm{H}), 5.98-5.85(\mathrm{~m}, 2 \mathrm{H}), 4.84(\mathrm{~d}, J=3.7$ $\mathrm{Hz}, 4 \mathrm{H})$;

${ }^{13} \mathrm{C}$ NMR (101 MHz, DMSO- $\left.d_{6}\right) \delta 161.6,134.2,128.3$, 119.10, 115.8, 103.0, 64.3;

LRMS $\left(\mathrm{ESI}^{-}\right) m / z: 289(\mathrm{M}-\mathrm{H}, 90 \%), 325(\mathrm{M}+\mathrm{Cl}$, $100 \%)$;

HRMS (ESI ${ }^{+}$): Calcd 291.1133 for $\mathrm{C}_{18} \mathrm{H}_{15} \mathrm{~N}_{2} \mathrm{O}_{2}[\mathrm{M}+\mathrm{H}]^{+}$; found, 291.1144.

Dimethyl 4,4'-(But-2-ene-1,4-diylbis(oxy))(Z)-dibenzoate (15e). Compound 15e was synthesized using general procedure 1 from methyl-4-hydroxybenzoate (14e) (5.51 g, 36.210 mmol), (Z)-1,4-dichloro-2-butene (5e) (1.72 mL, 16.46 $\mathrm{mmol})$, potassium carbonate $(5.000 \mathrm{~g}, 36.21 \mathrm{mmol})$, and potassium iodide $(0.600 \mathrm{~g}, 3.620 \mathrm{mmol})$ in acetonitrile $(150$ $\mathrm{mL})$ to afford the title compound $(2.640 \mathrm{~g}, 45 \%)$ as a white solid (mp 78-81 ${ }^{\circ} \mathrm{C}$ ).

${ }^{1} \mathrm{H}$ NMR (400 MHz, DMSO- $\left.d_{6}\right) \delta 7.91(\mathrm{~d}, J=8.9 \mathrm{~Hz}, 4 \mathrm{H})$, $7.08(\mathrm{~d}, J=8.9 \mathrm{~Hz}, 4 \mathrm{H}), 5.95-5.86(\mathrm{~m}, 2 \mathrm{H}), 4.84(\mathrm{~d}, J=4.1$ $\mathrm{Hz}, 4 \mathrm{H}), 3.82(\mathrm{~s}, 6 \mathrm{H})$;

${ }^{13} \mathrm{C}$ NMR (101 MHz, DMSO- $\left.d_{6}\right) \delta 166.3,162.5,131.7$, 128.8, 122.5, 115.2, 64.6, 52.3;

LRMS $\left(\mathrm{ESI}^{+}\right) \mathrm{m} / z: 357(\mathrm{M}+\mathrm{H}, 100 \%) ;$

HRMS $\left(\right.$ ESI $^{+}$): Calcd 357.1338 for $\mathrm{C}_{20} \mathrm{H}_{21} \mathrm{O}_{6}[\mathrm{M}+\mathrm{H}]^{+}$; found, 357.1348 . 
(Z)-4,4'-(But-2-ene-1,4-diylbis(oxy))dibenzaldehyde (15f). Compound $\mathbf{1 5 f}$ was synthesized using general procedure 1 from 4-hydroxybenzaldehyde (14f) (0.654 g, $5.324 \mathrm{mmol})$, (Z)-1,4-dichloro-2-butene (5e) (0.253 mL, $2.420 \mathrm{mmol})$, potassium carbonate $(0.735 \mathrm{~g}, 5.534 \mathrm{mmol})$, and potassium iodide $(0.040 \mathrm{~g}, 0.240 \mathrm{mmol})$ in acetonitrile $(50 \mathrm{~mL})$ to afford the title compound $(0.538 \mathrm{~g}, 75 \%)$ as a white solid (mp 90-93 $\left.{ }^{\circ} \mathrm{C}\right)$.

${ }^{1} \mathrm{H}$ NMR (400 MHz, $\left.\mathrm{CDCl}_{3}\right) \delta 9.90(\mathrm{~s}, 2 \mathrm{H}), 7.85(\mathrm{~d}, J=8.7$ $\mathrm{Hz}, 4 \mathrm{H}), 7.02$ (d, J = 8.7 Hz, 4H), 6.05-5.91 (m, 2H), 4.78 (d, $J=3.8 \mathrm{~Hz}, 4 \mathrm{H})$;

${ }^{13} \mathrm{C}$ NMR $\left(101 \mathrm{MHz}, \mathrm{CDCl}_{3}\right) \delta 190.9,163.4,132.2,130.5$, 128.4, 115.0, 64.6;

LRMS $\left(\mathrm{ESI}^{+}\right) \mathrm{m} / z: 297(\mathrm{M}+\mathrm{H}, 20 \%), 145(100)$;

HRMS (ESI ${ }^{+}$): Calcd 319.0941 for $\mathrm{C}_{18} \mathrm{H}_{16} \mathrm{O}_{4} \mathrm{Na}[\mathrm{M}+\mathrm{Na}]^{+}$; found, 319.0953 .

(Z)-N, $N^{\prime}$-((But-2-ene-1,4-diylbis(oxy))bis(4,1-phenylene))diacetamide (16). A solution of ( $Z$ )-4,4'-(but-2-ene-1,4diylbis(oxy))dianiline hydrochloride (8e) (0.100 g, 0.291 $\mathrm{mmol})$ and DIPEA $(0.200 \mathrm{~mL}, 1.164 \mathrm{mmol})$ in anhydrous $\mathrm{CH}_{2} \mathrm{Cl}_{2}(25 \mathrm{~mL})$ was stirred for $5 \mathrm{~min}$ before adding acetyl chloride $(0.166 \mathrm{~mL}, 2.328 \mathrm{mmol})$. The reaction mixture was then stirred at room temperature for $16 \mathrm{~h}$. The resulting reaction mixture was then concentrated in vacuo, diluted with ethyl acetate $(100 \mathrm{~mL})$, washed with water $(2 \times 100 \mathrm{~mL})$, and saturated with $\mathrm{NaHCO}_{3}(100 \mathrm{~mL})$. The organic layer was dried over $\mathrm{MgSO}_{4}$, concentrated in vacuo with the residue, adsorbed onto silica $(\sim 1.00 \mathrm{~g})$, and purified by flash chromatography $\left(2 \% \mathrm{CH}_{3} \mathrm{OH}\right.$ in $\left.\mathrm{CH}_{2} \mathrm{Cl}_{2}\right)$ to afford the title compound $(0.067 \mathrm{~g}$, $65 \%)$ as a white solid $\left(\mathrm{mp} 158-164{ }^{\circ} \mathrm{C}\right) .{ }^{46}$

${ }^{1} \mathrm{H}$ NMR (400 MHz, DMSO-d $\left.d_{6}\right) \delta 9.77$ (s, 2H), 7.46 (d, $J=$ $8.5 \mathrm{~Hz}, 4 \mathrm{H}), 6.89$ (d, $J=8.5 \mathrm{~Hz}, 4 \mathrm{H}), 5.86-5.80(\mathrm{~m}, 2 \mathrm{H}), 4.66$ (d, $J=1.5 \mathrm{~Hz}, 4 \mathrm{H}), 2.00(\mathrm{~s}, 6 \mathrm{H})$;

${ }^{13} \mathrm{C}$ NMR (101 MHz, DMSO- $\left.d_{6}\right) \delta 167.1,153.2,132.2$, $127.9,119.8,114.0,63.3,23.2$;

MS $\left(\mathrm{ESI}^{+}\right) m / z: 355(\mathrm{M}+\mathrm{H}, 100 \%), 377(\mathrm{M}+\mathrm{Na}, 25 \%)$.

(Z)-1,1'-((But-2-ene-1,4-diylbis(oxy))bis(4,1-phenylene))bis(3-ethylthiourea) (17). To a solution of (Z)-4,4'-(but-2-ene1,4-diylbis(oxy))dianiline hydrochloride (8e) (0.159 g, 0.465 $\mathrm{mmol})$ and TEA $(0.133 \mathrm{~mL}, 0.953 \mathrm{mmol})$ in $15 \mathrm{~mL}$ of anhydrous THF, ethyl isothiocyanate $(0.113 \mathrm{~mL}, 1.297 \mathrm{mmol})$ was added. The resulting mixture was heated at reflux for $6 \mathrm{~h}$ under a nitrogen atmosphere, cooled to room temperature, and concentrated in vacuo. The residue was taken up in EtOAc $(100 \mathrm{~mL})$; washed with water $(100 \mathrm{~mL}), 1 \mathrm{M} \mathrm{HCl}(100 \mathrm{~mL})$, and brine $(100 \mathrm{~mL})$; dried over $\mathrm{MgSO}_{4}$; concentrated in vacuo; and then purified by flash chromatography $\left(2 \% \mathrm{CH}_{3} \mathrm{OH}\right.$ in $\left.\mathrm{CH}_{2} \mathrm{Cl}_{2}\right)$ to afford the title compound $(0.069 \mathrm{~g}, 33 \%)$ as a white solid (mp $152-157^{\circ} \mathrm{C}$ ).

${ }^{1} \mathrm{H}$ NMR (400 MHz, acetone- $\left.d_{6}\right) \delta 8.53(\mathrm{~s}, 2 \mathrm{H}), 7.25$ (d, $J=$ $8.9 \mathrm{~Hz}, 4 \mathrm{H}), 6.96(\mathrm{~d}, J=8.9 \mathrm{~Hz}, 6 \mathrm{H}), 5.95-5.89(\mathrm{~m}, 2 \mathrm{H}), 4.78$ $(\mathrm{d}, J=4.0 \mathrm{~Hz}, 4 \mathrm{H}), 3.61(\mathrm{dq}, J=7.1,5.6 \mathrm{~Hz}, 4 \mathrm{H}), 1.14(\mathrm{t}, J=$ $7.2 \mathrm{~Hz}, 6 \mathrm{H})$;

${ }^{13} \mathrm{C}$ NMR (101 MHz, acetone- $\left.d_{6}\right) \delta 182.5,157.5,132.3$, 129.4, 127.6, 116.0, 65.2, 40.2, 14.7;

LRMS $\left(\mathrm{ESI}^{+}\right) \mathrm{m} / z: 445(\mathrm{M}+\mathrm{H}, 100 \%)$;

HRMS (ESI ${ }^{+}$): Calcd 445.1732 for $\mathrm{C}_{22} \mathrm{H}_{29} \mathrm{~N}_{4} \mathrm{O}_{2} \mathrm{~S}_{2}[\mathrm{M}+\mathrm{H}]^{+}$; found, 445.1743 .

(Z)-4,4'-(But-2-ene-1,4-diylbis(oxy))dibenzoic Acid (18). A solution of dimethyl 4,4'-(but-2-ene-1,4-diylbis(oxy))(Z)-dibenzoate (15e) $(0.400 \mathrm{~g}, 1.122 \mathrm{mmol})$ in $10 \% \mathrm{KOH}$ : THF $(2: 1,100 \mathrm{~mL})$ was refluxed for $1 \mathrm{~h}$. The resulting solution was then acidified ( $\mathrm{pH} 4$ and 5) with $0.25 \mathrm{M} \mathrm{HCl}$. The resulting precipitate was collected and washed with water $(25 \mathrm{~mL})$ to afford the title compound $(0.360 \mathrm{~g}, 98 \%)$ as a white solid (mp $248{ }^{\circ} \mathrm{C}$ (dec.) $) .^{47}$

${ }^{1} \mathrm{H}$ NMR (400 MHz, DMSO- $\left.d_{6}\right) \delta 7.89(\mathrm{~d}, J=8.5 \mathrm{~Hz}, 4 \mathrm{H})$, 7.05 (d, $J=8.5 \mathrm{~Hz}, 4 \mathrm{H}), 5.91$ (bs, $2 \mathrm{H}), 4.83$ (bs, $4 \mathrm{H}$ );

${ }^{13} \mathrm{C}$ NMR (101 MHz, DMSO- $\left.d_{6}\right) \delta 167.3,162.1,131.8$, 128.7, 123.7, 115.0, 64.5;

LRMS $\left(\mathrm{ESI}^{-}\right) \mathrm{m} / \mathrm{z}: 327(\mathrm{M}-\mathrm{H}, 100 \%)$;

HRMS $\left(\right.$ ESI $^{+}$): Calcd 351.0839 for $\mathrm{C}_{18} \mathrm{H}_{16} \mathrm{O}_{6} \mathrm{Na}[\mathrm{M}+\mathrm{Na}]^{+}$; found, 351.0853 .

(Z)-4,4' -(But-2-ene-1,4-diylbis(oxy))bis(N-methylbenzamide) (19). To a suspension of (Z)-4,4'-(but-2-ene-1,4diylbis(oxy))dibenzoic acid (18) (0.228 g, $0.690 \mathrm{mmol})$ in anhydrous $\mathrm{CH}_{2} \mathrm{Cl}_{2}(10 \mathrm{~mL}), \mathrm{DMF}$ (four drops) and oxalic chloride $\left(1.5 \mathrm{~mL}, 2 \mathrm{M}\right.$ in $\mathrm{CH}_{2} \mathrm{Cl}_{2}$ ) were added. The solution was then stirred at room temperature for $1 \mathrm{~h}$. The reaction mixture was concentrated in vacuo, taken up in anhydrous THF $(50 \mathrm{~mL})$, and $2 \mathrm{M} \mathrm{CH}_{3} \mathrm{NH}_{2}$ in THF $(2.76 \mathrm{~mL}, 0.171 \mathrm{~g}, 5.52$ $\mathrm{mmol}$ ) was added. Then, the mixture was stirred at room temperature for $1 \mathrm{~h}$. The resulting reaction mixture was concentrated in vacuo, adsorbed onto silica, and purified by flash chromatography $\left(0.35 \% \mathrm{NH}_{4} \mathrm{OH}, 2.5 \% \quad \mathrm{CH}_{3} \mathrm{OH}\right.$ in $\left.\mathrm{CH}_{2} \mathrm{Cl}_{2}\right)$ to afford the title compound $(0.106 \mathrm{~g}, 43 \%)$ as an off-white solid (mp $\left.128-131{ }^{\circ} \mathrm{C}\right)$.

${ }^{1} \mathrm{H}$ NMR (400 MHz, DMSO- $d_{6}$ ) $\delta 8.27(\mathrm{~m}, 2 \mathrm{H}), 7.80(\mathrm{~d}, J=$ $8.8 \mathrm{~Hz}, 4 \mathrm{H}), 7.02(\mathrm{~d}, J=8.8 \mathrm{~Hz}, 4 \mathrm{H}), 5.93-5.86(\mathrm{~m}, 2 \mathrm{H}), 4.80$ (d, $J=4.0 \mathrm{~Hz}, 4 \mathrm{H}), 2.76(\mathrm{~d}, J=4.5 \mathrm{~Hz}, 6 \mathrm{H})$;

${ }^{13} \mathrm{C}$ NMR (101 MHz, DMSO- $\left.d_{6}\right) \delta 166.5,160.7,129.3$, 128.8, 127.5, 114.6, 64.4, 26.6;

LRMS $\left(\mathrm{ESI}^{+}\right) \mathrm{m} / z: 355(\mathrm{M}+\mathrm{H}, 100 \%)$;

HRMS (ESI ${ }^{+}$): Calcd 355.1658 for $\mathrm{C}_{20} \mathrm{H}_{23} \mathrm{~N}_{2} \mathrm{O}_{4}[\mathrm{M}+\mathrm{H}]^{+}$; found, 445.1743 .

(Z)-1,4-Bis(4-(5-methyl-1,2,4-oxadiazol-3-yl)phenoxy)but2-ene (20). To a solution of (Z)-4,4' -(but-2-ene-1,4-diylbis(oxy))dibenzonitrile (15d) (0.298 g, $1.026 \mathrm{mmol})$ in acetonitrile $(50 \mathrm{~mL})$ at room temperature, hydroxylamine $(1.280 \mathrm{~mL}, 20.890 \mathrm{mmol})$ was added, and the mixture heated to reflux for $4 \mathrm{~h}$. On cooling, the mixture was concentrated in vacuo and the residue was adsorbed onto silica $(\sim 1.00 \mathrm{~g})$ and purified by flash chromatography $\left(10 \% \mathrm{CH}_{3} \mathrm{OH}\right.$ in $\left.\mathrm{CH}_{2} \mathrm{Cl}_{2}\right)$. The material was then carried through to the next step, without any further characterization.

To a solution of the $N$-hydroxybenzimidamide intermediate and $3 \AA$ molecular sieves in anhydrous THF $(50 \mathrm{~mL})$, acetyl chloride $(0.300 \mathrm{~mL}, 3.97 \mathrm{mmol})$ was added and heated at reflux for $16 \mathrm{~h}$. The resulting reaction mixture was diluted with a 1:1:1 mixture of $\mathrm{CH}_{3} \mathrm{OH} / \mathrm{EtOAc} / \mathrm{THF}(250 \mathrm{~mL})$, and the molecular sieves were washed with THF $(2 \times 100 \mathrm{~mL})$. The combined organic layers were concentrated in vacuo, and the residue was adsorbed onto silica $(\sim 1.00 \mathrm{~g})$ and purified by flash chromatography (30\% EtOAc in hexane) to afford an offwhite crystal ( $30 \mathrm{mg}, 7 \%$, two steps).

${ }^{1} \mathrm{H}$ NMR (400 MHz, DMSO- $\left.d_{6}\right) \delta 7.93(\mathrm{~d}, J=8.9 \mathrm{~Hz}, 4 \mathrm{H})$, $7.14(\mathrm{~d}, J=8.9 \mathrm{~Hz}, 4 \mathrm{H}), 6.02-5.77(\mathrm{~m}, 2 \mathrm{H}), 4.84(\mathrm{~d}, J=4.1$ $\mathrm{Hz}, 4 \mathrm{H}), 2.64(\mathrm{~s}, 6 \mathrm{H})$;

${ }^{13} \mathrm{C}$ NMR (101 MHz, DMSO- $\left.d_{6}\right) \delta 177.1,167.3,160.5$, 128.6, 128.4, 118.8, 115.4, 64.10, 12.0;

LRMS $\left(\mathrm{ESI}^{+}\right) \mathrm{m} / z: 405(\mathrm{M}+\mathrm{H}, 100 \%), 321$ (25);

HRMS (ESI ${ }^{+}$): Calcd 405.1563 for $\mathrm{C}_{22} \mathrm{H}_{21} \mathrm{~N}_{4} \mathrm{O}_{4}[\mathrm{M}+\mathrm{H}]^{+}$; found, 405.1559 .

(Z)-4,4'-(But-2-ene-1,4-diylbis(oxy))dibenzimidamide (21). Ammonium chloride $(0.450 \mathrm{~g}, 8.413 \mathrm{mmol})$ was added to a 2 $\mathrm{M}$ solution of trimethylaluminum in toluene $(4.05 \mathrm{~mL}, 8.100$ 
mmol) at $0{ }^{\circ} \mathrm{C}$ under a nitrogen atmosphere. The suspension was then warmed to room temperature before dropwise addition of a solution of (Z)-4,4' -(but-2-ene-1,4-diylbis(oxy))dibenzonitrile (15d) (0.401 g, $1.380 \mathrm{mmol})$ in anhydrous toluene $(50 \mathrm{~mL})$. After complete addition, the reaction was then heated to $80{ }^{\circ} \mathrm{C}$ for $16 \mathrm{~h}$. The resulting reaction mixture was then cooled to room temperature and poured into a slurry of silica gel $(\sim 2.00 \mathrm{~g})$ and chloroform $(20 \mathrm{~mL})$. The silica plug was then washed with $10 \% \mathrm{CH}_{3} \mathrm{OH}$ in $\mathrm{CH}_{2} \mathrm{Cl}_{2}(200 \mathrm{~mL})$. The filtrate was then concentrated in vacuo, diluted with $100 \mathrm{~mL}$ of EtOAc $(100 \mathrm{~mL})$, washed with water $(100 \mathrm{~mL})$ and brine $(100$ $\mathrm{mL}$ ), dried over $\mathrm{MgSO}_{4}$, and concentrated in vacuo to afford the title compound $(0.098 \mathrm{~g}, 45 \%)$ as a white solid (mp 212$\left.213{ }^{\circ} \mathrm{C}\right) .{ }^{48}$

${ }^{1} \mathrm{H}$ NMR $\left(400 \mathrm{MHz}, \mathrm{DMSO}-d_{6}\right) \delta 7.79(\mathrm{~d}, J=8.9 \mathrm{~Hz}, 4 \mathrm{H})$, $7.14(\mathrm{~d}, J=8.9 \mathrm{~Hz}, 4 \mathrm{H}), 6.02-5.78(\mathrm{~m}, 2 \mathrm{H}), 4.85(\mathrm{~d}, J=4.2$ $\mathrm{Hz}, 4 \mathrm{H})$;

${ }^{13} \mathrm{C}$ NMR (101 MHz, DMSO- $\left.d_{6}\right) \delta 162.0,134.7,128.7$, 119.6, 116.3, 103.5, 64.7;

MS $\left(\mathrm{ESI}^{+}\right) \mathrm{m} / z: 325(\mathrm{M}+\mathrm{H}, 10 \%) 269$ (100\%), 335 (80\%).

2-((Z)-4-(((Z)-4-(4-((E)-(Carbamimidoylimino)methyl)phenoxy)but-2-en-1-yl)oxy)benzylidene)hydrazine-1-carboximidamide (22). General Procedure 11: A solution of (Z)-4,4'(but-2-ene-1,4-diylbis(oxy))dibenzaldehyde (15f) (0.100 g, $0.337 \mathrm{mmol}$ ), aminoguanidine hydrochloride $(0.082 \mathrm{~g}, 0.741$ $\mathrm{mmol}$ ), and a drop of $10 \% \mathrm{HCl}$ in ethanol $(3 \mathrm{~mL})$ was subjected to microwave irradiation at $120{ }^{\circ} \mathrm{C}$ for $30 \mathrm{~min}$. The reaction mixture was then concentrated to afford a white precipitate. The precipitate was then suspended in ether $(25$ $\mathrm{mL})$, sonicated, and filtered to afford the title compound (0.135 g, 98\%) as an off-white solid (mp $232{ }^{\circ} \mathrm{C}$ (dec.)).

${ }^{1} \mathrm{H}$ NMR (400 MHz, DMSO-d 6 ) $\delta 11.96$ (brs, 2H), 8.12 (s, $2 \mathrm{H}), 7.77(\mathrm{~m}, 12 \mathrm{H}), 7.04(\mathrm{~d}, J=8.4 \mathrm{~Hz}, 4 \mathrm{H}), 5.90$ (brs, $2 \mathrm{H})$, $4.81(\mathrm{~d}, J=2.2 \mathrm{~Hz}, 4 \mathrm{H})$;

${ }^{13} \mathrm{C}$ NMR $\left(101 \mathrm{MHz}, \mathrm{CD}_{3} \mathrm{OD}\right) \delta 152.9,147.6,139.8,121.0$, 120.0, 118.1, 106.6, 56.0;

LRMS $\left(\mathrm{ESI}^{-}\right) \mathrm{m} / z: 443(\mathrm{M}+\mathrm{Cl}, 100 \%)$;

HRMS $\left(\mathrm{ESI}^{+}\right.$): Calcd 409.2100 for $\mathrm{C}_{20} \mathrm{H}_{25} \mathrm{~N}_{8} \mathrm{O}_{2}[\mathrm{M}+\mathrm{H}]^{+}$; found, 409.2114 .

\section{ASSOCIATED CONTENT}

\section{S Supporting Information}

The Supporting Information is available free of charge on the ACS Publications website at DOI: 10.1021/acsomega.7b00273.

${ }^{1} \mathrm{H}$ and ${ }^{13} \mathrm{C}$ NMR spectra of the compounds synthesized herein (PDF)

Plasmids and bacterial strains used and constructed in this work were confirmed by DNA sequencing and are listed in the table (XLSX)

\section{AUTHOR INFORMATION}

\section{Corresponding Author}

*E-mail: adam.mccluskey@newcastle.edu.au. Phone: +61(0) 24921 6486. Fax: +61(0) 249215472.

\section{ORCID $\odot$}

Mohammed K. Abdel-Hamid: 0000-0001-5508-6153

Jennette A. Sakoff: 0000-0002-7009-5792

Christopher P. Gordon: 0000-0001-7583-5609

Adam McCluskey: 0000-0001-7125-863X

\section{Present Address}

\#Department of Applied Biology and Chemical Technology, The State Key Laboratory of Chirosciences, The Hong Kong Polytechnic University, Hung Hom, Kowloon, Hong Kong SAR, P. R. China (C.M.).

\section{Notes}

The authors declare no competing financial interest.

\section{ACKNOWLEDGMENTS}

This work was supported by the Australian Cancer Research Foundation, Ramaciotti Foundation, the Australian Research Council, National Health and Medical Research Council (Australia), and the University of Newcastle Early Career Research Grant (C.M.). C.P.G. is the recipient of an ARC DECRA fellowship. P.J.C. acknowledges the receipt of a University of Newcastle Postgraduate Research Scholarship.

\section{ABBREVIATIONS}

PPI, protein-protein interaction; MIC, minimum inhibitory concentration; FDA, Food and Drug Administration; ESKAPE, Enterococcus faecium, Staphylococcus aureus, Klebsiella pneumoniae, Acinetobacter baumanii, Pseudomonas aeruginosa, and Enterobacter species; MOE, molecular operating environment; $\mu \mathrm{Wave}$, microwave

\section{REFERENCES}

(1) Andersson, D. I.; Hughes, D. Antibiotic Resistance and Its Cost: Is It Possible to Reverse Resistance? Nat. Rev. Microbiol. 2010, 8, 260271.

(2) Chait, R.; Palmer, A. C.; Yelin, I.; Kishony, R. Pervasive Selection for and against Antibiotic Resistance in Inhomogeneous Multistress Environments. Nat. Commun. 2016, 7, No. 10333.

(3) Centers for Disease Control and Prevention (CDC). Antibiotic Resistance Threats in the United States. http://www.cdc.gov/ drugresistance/threat-report-2013/pdf/ar-threats-2013-508.pdf.

(4) Bush, K.; Courvalin, P.; Dantas, G.; Davies, J.; Eisenstein, B.; Huovinen, P.; Jacoby, G. A.; Kishony, R.; Kreiswirth, B. N.; Kutter, E.; Lerner, S. A.; Levy, S.; Lewis, K.; Lomovskaya, O.; Miller, J. H.; Mobashery, S.; Piddock, L. J. V.; Projan, S.; Thomas, C. M.; Tomasz, A.; Tulkens, P. M.; Walsh, T. R.; Watson, J. D.; Witkowski, J.; Witte, W.; Wright, G.; Yeh, P.; Zgurskaya, H. I. Tackling Antibiotic Resistance. Nat. Rev. Microbiol. 2011, 9, 894-896.

(5) Wright, G. D. Molecular Mechanisms of Antibiotic Resistance. Chem. Commun. 2011, 47, 4055.

(6) FDA. Novel Drugs 2015 Summary, 2016.

(7) Boucher, H. W.; Talbot, G. H.; Bradley, J. S.; Edwards, J. E.; Gilbert, D.; Rice, L. B.; Scheld, M.; Spellberg, B.; Bartlett, J. Bad Bugs, No Drugs: No ESKAPE! An Update from the Infectious Diseases Society of America. Clin. Infect. Dis. 2009, 48, 1-12.

(8) Mielczarek, M.; Devakaram, R. V.; Ma, C.; Yang, X.; Kandemir, H.; Purwono, B.; Black, D. S.; Griffith, R.; Lewis, P. J.; Kumar, N. Synthesis and Biological Activity of Novel Bis-Indole Inhibitors of Bacterial Transcription Initiation Complex Formation. Org. Biomol. Chem. 2014, 12, 2882-2894.

(9) Gordon, C. P.; Williams, P.; Chan, W. C. Attenuating Staphylococcus Aureus Virulence Gene Regulation: A Medicinal Chemistry Perspective. J. Med. Chem. 2013, 56, 1389-1404.

(10) Ma, C.; Yang, X.; Kandemir, H.; Mielczarek, M.; Johnston, E. B.; Griffith, R.; Kumar, N.; Lewis, P. J. Inhibitors of Bacterial Transcription Initiation Complex Formation. ACS Chem. Biol. 2013, 8, 1972-1980.

(11) Butler, M. S.; Cooper, M. A. Antibiotics in the Clinical Pipeline in 2011. J. Antibiot. 2011, 64, 413-425.

(12) Cooper, M. A.; Shlaes, D. Fix the Antibiotics Pipeline. Nature 2011, 472, 32. 
(13) Policy, IDSA Public. The $10 \times$ '20 Initiative: Pursuing a Global Commitment to Develop $10 \mathrm{New}$ Antibacterial Drugs by 2020. Clin. Infect. Dis. 2010, 50, 1081-1083.

(14) Yin, Z.; Whittell, L. R.; Wang, Y.; Jergic, S.; Ma, C.; Lewis, P. J.; Dixon, N. E.; Beck, J. L.; Kelso, M. J.; Oakley, A. J. Bacterial Sliding Clamp Inhibitors That Mimic the Sequential Binding Mechanism of Endogenous Linear Motifs. J. Med. Chem. 2015, 58, 4693-4702.

(15) Ma, C.; Yang, X.; Lewis, P. J. Bacterial Transcription Inhibitor of RNA Polymerase Holoenzyme Formation by Structure-Based Drug Design: From in Silico Screening to Validation. ACS Infect. Dis. 2016, 2, 39-46.

(16) Ma, C.; Yang, X.; Lewis, P. J. Bacterial Transcription as a Target for Antibacterial Drug Development. Microbiol. Mol. Biol. Rev. 2016, 80, 139-160.

(17) Modell, A. E.; Blosser, S. L.; Arora, P. S. Systematic Targeting of Protein-Protein Interactions. Trends Pharmacol. Sci. 2016, 37, 702713.

(18) Arkin, M. R.; Tang, Y.; Wells, J. A. Small-Molecule Inhibitors of Protein-Protein Interactions: Progressing toward the Reality. Chem. Biol. 2014, 21, 1102-1114.

(19) Arkin, M. R.; Wells, J. A. Small-Molecule Inhibitors of ProteinProtein Interactions: Progressing towards the Dream. Nat. Rev. Drug Discovery 2004, 3, 301-317.

(20) Russell, R. B.; Alber, F.; Aloy, P.; Davis, F. P.; Korkin, D.; Pichaud, M.; Topf, M.; Sali, A. A Structural Perspective on ProteinProtein Interactions. Curr. Opin. Struct. Biol. 2004, 14, 313-324.

(21) Sperandio, O.; Reynès, C. H.; Camproux, A.; Villoutreix, B. O. Rationalizing the Chemical Space of Protein-protein Interaction Inhibitors. Drug Discovery Today 2010, 15, 220-229.

(22) Doherty, G. P.; Meredith, D. H.; Lewis, P. J. Subcellular Partitioning of Transcription Factors in Bacillus Subtilis. J. Bacteriol. 2006, 188, 4101-4110.

(23) Robledo, R.; Atkinson, B. L.; Gottesman, M. E. Escherichia Coli Mutations That Block Transcription Termination by Phage HK022 Nun Protein. J. Mol. Biol. 1991, 220, 613-619.

(24) Court, D. L.; Patterson, T. A.; Baker, T.; Costantino, N.; Mao, X.; Friedman, D. I. Structural and Functional Analyses of the Transcription-Translation Proteins NusB and NusE. J. Bacteriol. 1995, 177, 2589-2591.

(25) Luo, X.; Hsiao, H.; Bubunenko, M.; Weber, G.; Court, D. L.; Gottesman, M. E.; Urlaub, H.; Wahl, M. C. Structural and Functional Analysis of the E. coli NusB-S10 Transcription Antitermination Complex. Mol. Cell 2008, 32, 791-802.

(26) Bubunenko, M.; Baker, T.; Court, D. L. Essentiality of Ribosomal and Transcription Antitermination Proteins Analyzed by Systematic Gene Replacement in Escherichia Coli Essentiality of Ribosomal and Transcription Antitermination Proteins Analyzed by Systematic Gene Replacement in Escherichia coli. J. Bacteriol. 2007, 189, 2844-2853.

(27) Quan, S.; Zhang, N.; French, S.; Squires, C. L. Transcriptional Polarity in rRNA Operons of Escherichia Coli nusA and nusB Mutant Strains. J. Bacteriol. 2005, 187, 1632-1638.

(28) Stagno, J. R.; Altieri, A. S.; Bubunenko, M.; Tarasov, S. G.; Li, J.; Court, D. L.; Byrd, R. A.; Ji, X. Structural Basis for RNA Recognition by NusB and NusE in the Initiation of Transcription Antitermination. Nucleic Acids Res. 2011, 39, 7803-7815.

(29) Das, R.; Loss, S.; Li, J.; Waugh, D. S.; Tarasov, S.; Wingfield, P. T.; Byrd, R. A.; Altieri, A. S. Structural Biophysics of the NusB: NusE Antitermination Complex. J. Mol. Biol. 2008, 376, 705-720.

(30) Cossar, P. J.; Ma, C.; Gordon, C. P.; Ambrus, J. I.; Lewis, P. J.; McCluskey, A. Identification and Validation of Small Molecule Modulators of the NusB-NusE Interaction. Bioorg. Med. Chem. Lett. 2017, 27, 162-167.

(31) Corbeil, C. R.; Williams, C. I.; Labute, P. Variability in Docking Success Rates due to Dataset Preparation. J. Comput. Aided. Mol. Des. 2012, 26, 775-786.

(32) Molecular Operating Environment (MOE). Chemical Computing Group: Montreal, Quebec, Canada, 2011.
(33) Dhivya, S.; Suresh, K. C.; Vijayakumar, B.; Rethavathi, J.; Ananth, M. K.; Jaynthy, C. Pharmacophore based drug designing of plant metabolite Axillarin from Inula Britannica against native HIV1protease. Int. J. Pharm. Bio. Sci. 2012, 3, 977-986.

(34) Tarleton, M.; Robertson, M. J.; Gilbert, J.; Sakoff, J. A.; McCluskey, A. Library synthesis and cytotoxicity of a family of 2phenybutene-3-nitriles. MedChem Comm 2011, 2, 31-37.

(35) McKim, J., Jr. Building a tiered approach to in vitro predictive toxicity screening: a focus on assays with in vivo relevance. Comb. Chem. High Throughput Screening 2010, 13, 188-206.

(36) Schwartz, B. S.; Graber, C. J.; Diep, B. A.; Basuino, L.; PerdreauRemington, F.; Chambers, H. F. Doxycycline, Not Minocycline, Induces Its Own Resistance in Multidrug-Resistant, CommunityAssociated Methicillin-Resistant Staphylococcus aureus Clone USA300. Clin. Infect. Dis. 2009, 48, 1483-1484.

(37) Juan, C.; Zamorano, L.; Pérez, J. L.; Ge, Y.; Oliver, A. Activity of a New Antipseudomonal Cephalosporin, CXA-101 (FR264205), against Carbapenem-Resistant and Multidrug-Resistant Pseudomonas aeruginosa Clinical Strains. Antimicrob. Agents Chemother. 2010, 54, $846-851$.

(38) Johnson, A. S.; van Hork, S.; Lewis, P. J. Dynamic Localization of Membrane Proteins in Bacillus subtilis. Microbiology 2004, 150, $2815-2824$

(39) Doherty, G. P.; Meredith, D. H.; Lewis, P. J. Subcellular Partitioning of Transcription Factors in Bacillus subtilis. J. Bacteriol. 2006, 188, 4101-4110.

(40) Heckman, K. L.; Pease, L. R. Gene Splicing and Mutagenesis by PCR-Driven Overlap Extension. Nat. Protoc. 2007, 2, 924-932.

(41) Yang, X.; Lewis, P. J. Overproduction and Purification of Recombinant Bacillus subtilis RNA Polymerase. Protein Expression Purif. 2008, 59, 86-93.

(42) Hsu, L.-Y.; Nien, C.-Y.; Huang, W.-M.; Hsu, S.-C.; Chang, T.-C. Synthesis and Protective Effects of Bis $\{4-[\mathrm{N}, \mathrm{N}-\mathrm{Di}$-(Carboxymethyl)amino]phenoxy $\}$ alkane Derivatives on UVA-Induced Production of MMP-1 in Human Skin Fibroblasts. Chem. Pharm. Bull. 2014, 62, $867-874$.

(43) Asha, S. K.; Kavita, K.; Das, P. K.; Ramakrishnan, S. Relaxation Behavior of Twin Nonlinear Optical Chromophores: Effect of the Spacer Length. Chem. Mater. 1999, 11, 3352-3358.

(44) Wood, C. S.; Ronson, T. K.; Belenguer, A. M.; Holstein, J. J.; Nitschke, J. R. Two-Stage Directed Self-Assembly of a Cyclic [3] catenane. Nat. Chem. 2015, 7, 354-358.

(45) Roversi, E.; Monnat, F.; Vogel, P.; Schenk, K.; Roversi, P. Substituent Effect on the Competition between Hetero-Diels-Alder and Cheletropic Additions of Sulfur Dioxide to 1-Substituted Buta-1,3Dienes. Helv. Chim. Acta 2002, 85, 733-760.

(46) Harfenist, M. Diamphenethide-a New Fasciolicide Active against Immature Parasites. Pestic. Sci. 1973, 4, 871-882.

(47) Rush, A. M.; Nelles, D. A.; Blum, A. P.; Barnhill, S. A.; Tatro, E. T.; Yeo, G. W.; Gianneschi, N. C. Intracellular mRNA Regulation with Self-Assembled Locked Nucleic Acid Polymer Nanoparticles. J. Am. Chem. Soc. 2014, 136, 7615-7618.

(48) Donkor, I. O.; Tidwell, R. R.; Jones, S. K. Pentamidine Congeners. 2. 2-Butene-Bridged Aromatic Diamidines and Diimidazolines as Potential Anti-Pneumocystis Carinii Pneumonia Agents. J. Med. Chem. 1994, 37, 4554-4557. 